\title{
Significado y Mente en Aristóteles
}

\author{
Fabián Mié ${ }^{1}$
}

\begin{abstract}
Aristotle's concern for meaning and mind, in the compact opening lines of De Interpretatione (16a3-8) together with the sequel of the next six chapters of this treatise, have been read (both historically and contemporary) in heavily different ways. Discrepancies reach even the kind of project this text carries out, whether engaged in a theory of language and meaning closely linked to Aristotle's explanation of mental representation or rather engaged primarily in dialectical refutation without particular interest on meaning and mind. Yet, it is held -almost without exception among contemporary interpreters- that Aristotle explains (there and everywhere) meaning in terms of mental representation, and that somehow he takes mental representation to be dependent strongly on images which produce a mental likeness to the external object. So it goes nearly uncontested that mainly imagination must be responsible for meaning. This is a controversial assumption that I will dispute here by providing a detailed account of $D e$ Interpretatione (and some other related texts of the Organon) and by uncovering the psychological support for semantics (mostly found in De Anima and Parva Naturalia). Two main theses will be here argued for. First, I will contend that Aristotle is committed to a moderate linguistic conventionalism by which he can manage to preserve the intentional content of significant sounds as well as to avoid the shortcomings of any explanation of meaning in terms of images and likeness. Second, I will give several reasons Aristotle would have for explaining meaning on the basis of intellect rather than imagination. As a result, Aristotle will be exonerated from the common blame of having countenanced a natural imitation (based on images) to secure the reference of words.
\end{abstract}

\footnotetext{
${ }^{1}$ Quisiera agradecer a los editores de JAP por haber aceptado este artículo para su publicación. A lo largo de la extensa elaboración de este artículo me he beneficiado de las valiosas críticas y comentarios de colegas cuyo elevado número sea tal vez una justificación para agradecer anónimamente aquí a todos y cada uno. Debo mencionar, al menos, las instituciones que me han permitido presentar partes y versiones de este material: I Simposio de la Asociación Argentina de Filosofía Antigua (Biblioteca Nacional, Buenos Aires), Università degli Studi di Macerata, Universidad de los Andes (Chile), Universidad de Buenos Aires y Academia Nacional de Ciencias (Buenos Aires). Investigación subvencionada por Proyectos CONICET PIP 2012-2014 11220110100094 y UNL CAI+D 2011 PACT PI B50120110100012. La etapa final de la investigación fue posible gracias a becas de la Alexander von Humboldt-Stiftung y del Deutscher Akademischer Austauschdienst (2017) en la Ludwig Maximilians-Universität, München; a esas nobles instituciones y sobre todo a la generosa hospitalidad y a las discusiones con mi anfitrión, el Prof. Dr. Christof Rapp, debo un profundo agradecimiento. Este artículo es de alguna manera una contraparte de una publicación anterior sobre "Nombre y significado en Platón, Crátilo 384a8391a4: El modelo técnico del lenguaje como solución a la controversia entre naturalismo y convencionalismo" (Hypnos 33 (2014), 34 (2015)).
} 


\section{La semántica de Aristóteles}

Los seis primeros capítulos de De interpretatione contienen una concisa presentación de la semántica aristotélica e incluyen una apretada mención a la relación que guardan el lenguaje y la mente con el mundo. Según De interpretatione 16a13-15, a los términos lingüísticos corresponden pensamientos o conceptos (vó $\mu \alpha, 16 \mathrm{a} 10$, a14) provistos de una validez objetiva, que Aristóteles les reconoce en virtud de que son $\pi \alpha \theta \eta \dot{\mu} \mu \alpha \tau \alpha \tau \tilde{\eta} \varsigma$

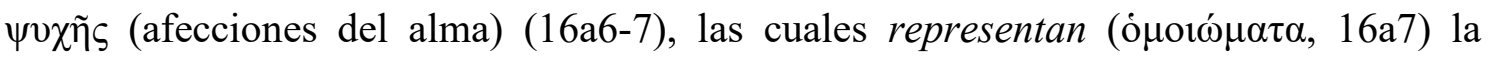
realidad extramental (16a6-8) de la misma manera para todos los humanos (16a6). En 16a8-9, Aristóteles deslinda su programa del que desarrolla probablemente en De Anima III, donde predomina la consideración psicológica sobre la formación de las representaciones mentales al nivel de las distintas facultades. Más allá de la cuestión que está envuelta en ese discrimen, las tesis generales de Aristóteles entrañan evidentemente compromisos teóricos importantes acerca del significado y la mente, que merecen una examinación detallada.

El estado actual de la cuestión muestra una marcada discrepancia acerca de la lectura del pasaje inicial de De Interpretatione, tanto acerca de cuáles son las tesis y compromisos aristotélicos que estarían implícitos en 16a3-8 como también acerca de su relación con los capítulos posteriores de la denominada sección lingüística, i.e. De interpretatione 16. En vista de estas discrepancias, hay autores que apuntaron módicamente a aclarar los principales conceptos envueltos en 16a3-8. Ésta es la estrategia que aquí también trataré de implementar como un paso previo necesario para defender dos tesis principales. En primer lugar, sostendré que Aristóteles acepta un convencionalismo lingüístico moderado que, en línea con una posición defendida en el Cratylus platónico, le permite al estagirita preservar el contenido intencional de los sonidos significativos a través de los cuales se expresa de qué manera captamos el mundo. Una de las principales sugerencias que al respecto formularé será que la tesis aristotélica sobre el significado tiene un rasgo externista. Mi segunda contribución principal consistirá en tratar de hacer justicia a la idea básica de De Interpretatione, según la cual el significado es el contenido de un sonido significativo convencional que está correlacionado con un tipo de representación mental en la cual está involucrado principalmente el intelecto. Es interesante que esta segunda tesis interpretativa revierte sobre la primera, ya que me permitirá exonerar a Aristóteles de la acusación común según la cual la referencia de las palabras a las cosas del mundo 
sería explicada por él con ayuda del modelo de la semejanza ligada al naturalismo lingüistico. $^{2}$

Mi objetivo en este artículo es ofrecer una respuesta a las dos cuestiones aludidas más arriba, i.e. me propongo identificar las tesis principales de Aristóteles acerca del significado, los conceptos y la mente, para lo cual, enfocaré mi consideración en el argumento programático de De Interpretatione 1-6. Un objetivo subsidiario importante es aclarar cuál es el proyecto teórico general de De Interpretatione en relación con su teoría de las facultades mentales así como también en relación con la tradición semántica antigua y con algunas discusiones actuales en este campo. En relación con estas cuestiones, puede ser conveniente anticipar que la lectura general que aquí favoreceré comparte la línea interpretativa general de Deborah Modrak, ya que considero que en De Interpretatione 1-6 Aristóteles plantea una tesis acerca del significado que entronca su proyecto en la discusión del Cratylus platónico. ${ }^{3}$ Reintegrar De Interpretatione a ese marco histórico-conceptual, al que prestaron atención comentadores como Amonio y Proclo, es algo que ha sido frecuentemente pasado por alto entre los intérpretes modernos, a pesar de algunos beneficios interpretativos bastante evidentes que de allí pueden obtenerse. Por ejemplo, a partir de tal enraizamiento es posible realizar la elemental identificación de la manera en que Aristóteles plantea su discusión acerca del significado a través de la distinción de los diferentes roles que desempeñan las unidades semánticas, i.e. el sustantivo, el predicado nominal y verbal y la proposición (i.e. el programa anunciado en 16a1-2), algo que Platón había anticipado ya en el Cratylus. La incidencia de este diálogo en el enfoque de De Interpretatione permite también explicar más convincentemente 16a3-8 en términos de una discusión acerca de la manera en que las voces convencionales adquieren un significado objetivamente válido y se relacionan con la realidad extramental. Un aspecto ulterior implícito de mi visión general sobre la teoría

${ }^{2}$ Ronald Polansky and Mark Kuczewski, "Speech and Thought, Symbol and Likeness: Aristotle's De Interpretatione 16a3-9," ["Speech and Thought"] Apeiron: A Journal for Ancient Philosophy and Science 23/1 (1990): 51-63, se propusieron aclarar los conceptos principales de Int. 16a3-9. Este empeño puede ser saludado en vista de la disparidad de juicios existentes sobre las intenciones, el programa, las tesis e incluso la importancia de Int. 1-6. Considerar la disparidad de opiniones que existen desde la antigüedad acerca de Int. puede ser una labor instructiva para el historiador de la filosofía y, en ocasiones, una inmersión fascinante en la historia de la semántica. En mi propia discusión e interés tengo principalmente en cuenta el punto de vista de los comentadores recientes, aunque hay notorias líneas de continuidad con algunas discusiones antiguas y medievales, a las que sólo podré prestar aquí una atención limitada.

${ }^{3}$ Cfr. Deborah K. W. Modrak, Aristotle's Theory of Language and Meaning [Language and Meaning], Cambridge (U.K): Cambridge University Press, 2001. 
aristotélica del significado (cfr. infra 6. y 6.3), está constituido por el hecho de que considero que Aristóteles toma los significados como funciones de la captación mental de la realidad extra-lingüística. En tal sentido, le atribuyo a Aristóteles un enfoque compartido por los neofregeanos actuales: los sentidos son modos de presentación del referente y éste los determina (metafísicamente). ${ }^{4}$

Este enfoque general no está exento de controversias. Presuponiendo una cierta lectura sobre los "tres estadios de la investigación" de Analíticos Segundos II, David Charles sostuvo que para Aristóteles sería posible captar el significado de un nombre sin poseer un conocimiento de la existencia ni de la esencia del objeto o referente. ${ }^{5}$ Resulta interesante comprobar que Charles le atribuye a Aristóteles una tesis sobre la manera de fijar la referencia que sería alternativa tanto con respecto a la kripkeana (por mera conexión causal del nombre con el referente) como también a la fregeana (por la disposición de información suficiente sobre el objeto, que nos capacita para diferenciar un objeto de otros). La alternativa aristotélica consistiría en que quien entiende (el significado de) un nombre obtiene cierta información sobre el objeto, y se forma una hipótesis o un concepto general, pero sin tener que conocer ya con ello las instancias (existencia) de la clase relevante ni la esencia de los objetos de la clase. Sin embargo, Charles admite que la fijación meramente causal de la referencia no puede explicar adecuadamente cómo piensa Aristóteles al respecto, ya que, para el estagirita, quien entiende el significado está ligado constitutivamente a la clase de cosa externa en la medida en que ésta produce un efecto de carácter epistémico sobre la mente. La discusión que se puede mantener con Charles es acerca del alcance que hay que darle a "epistémico" en esta última afirmación. Nótese, sin embargo, que Charles también rechaza una fijación internista del significado, i.e. por medio de meras representaciones mentales y sin que incida la manera en que el mundo se presenta al sujeto. Más allá de otras consideraciones, la interpretación de Charles representa una lectura con acentuaciones diferentes a la que presentaré aquí, en la medida en que él sigue insistiendo en la separación entre significado lingüístico y conocimiento del referente externo.

${ }^{4}$ Gareth Evans, The Varieties of Reference. John McDowell (ed.), Oxford: Oxford University Press, 1982; John McDowell, "Singular Thought and the Extent of Inner Space," en Meaning, Knowledge, and Reality, 228-259, Cambridge (Mass.): Harvard University Press, 1998a. Estos autores sostienen que usar un nombre supone la habilidad de formarse ciertos pensamientos acerca de su referente y ser capaz de individualizarlo.

${ }^{5}$ Cfr. David Charles, Aristotle on Meaning and Essence [Meaning and Essence], Oxford: Oxford University Press, 2000, pp. 161 ss. (n. 35), passim. 
Invirtiendo un dictum de Charles ("Semantics is one thing, epistemology another"), quisiera afirmar que en De Interpretatione (y otros tratados) Aristóteles presenta una concepción del significado con una marcada impronta epistémica; de tal manera que el mero hecho de comprender el significado de una palabra requiere competencias epistémicas bastante robustas por parte del usuario ya que para comprender el significado se debe estar en condiciones epistémicas de tener creencias acerca del referente externo. Lo que propongo es que el vínculo que puede establecer un usuario normal del lenguaje -i.e. no sólo quien posee conocimiento científico acerca de los objetos involucradosentre sus propias creencias acerca de los objetos reales designados y los nombres de clases naturales que designan esos objetos descansa en un acervo de conocimientos acerca del mundo en el cual ese usuario ya se encuentra situado desde el primer momento. Habría, entonces, una vinculación entre, por un lado, el hecho de que el usuario aristotélico del lenguaje esté desde el inicio de su ejercicio comprensivo (comprensión de los significados) ya en un medio lingüístico, y, por otro lado, la disposición de ciertos conocimientos sobre el mundo en el cual el ser humano está desde el mismo inicio de su experiencia comprensiva (la cual, por lo anterior, se viabiliza en el medio del lenguaje natural). Ésta es la razón por la cual la empresa semántica y la epistémica no pueden correr por carriles separados. Pero además, el usuario del lenguaje debe percatarse, de alguna manera, de que su propia comprensión del significado de las palabras supone un cierto conocimiento -i.e. no necesariamente una demostración ni una certeza infalibleacerca de cómo son las cosas designadas; es decir, él debe ser epistémicamente autoconsciente en este aspecto. Esto implica que con la sola comprensión del significado no está ya dado un conocimiento pleno y suficiente de las propiedades causales del objeto ni una taxonomía completa de la especie en cuestión. Como consecuencia de todo esto, el uso normal del lenguaje requiere una interacción epistémica -aun cuando ésta se delegue parcialmente en un experto- con el mundo.

\subsection{De Interpretatione y la semántica antigua}

A pesar de la reconocible importancia que para una correcta ubicación históricosistemática de De Interpretatione tiene la plausible filiación de este breve tratado con el Cratylus platónico, no es mi plan examinar aquí en detalle esa posible influencia. Como es sabido, el Cratylus ha sido interpretado por la crítica moderna de las maneras más 
opuestas; se le atribuyó tanto una posición favorable al naturalismo lingüístico como también otra inclinada hacia el convencionalismo. Esta discrepancia hace que resulte controvertido determinar cuál puede ser exactamente la posición platónica que impactaría en De Interpretatione. Lidiaré aquí con este complejo asunto sólo muy esquemáticamente. Lo que trataré de hacer, en cambio, es perfilar someramente la discusión en torno al naturalismo y al convencionalismo lingüísticos, a lo cual hay que añadir la disputa sobre la teoría de la referencia, como el genuino punto de partida de la propia discusión de De Interpretatione. Para trazar ese perfil me serviré de dos visiones opuestas sobre la recepción aristotélica del Cratylus.

La primera de ellas es la de Modrak, para quien, resumidamente, De Interpretatione defiende el convencionalismo al nivel de la relación entre lenguaje y significado, mientras que mantendría el naturalismo con respecto a la relación entre significado y referencia. Modrak insiste en que ésta es la respuesta aristotélica al problema del significado planteado en el Cratylus. Su lectura de Aristóteles se complementa con la adjudicación de una teoría descriptiva de la referencia y una aprehensión del significado en términos del contenido intencional de estados psíquicos que son expresados por palabras. Tales estados mentales serían los mismos para todos los seres humanos, en cuanto que copiarían estados de cosas extramentales. Entre los estados mentales y el significado, por un lado, y la realidad, por el otro, existiría una relación natural, opuesta a otra meramente convencional. ${ }^{6}$

La segunda visión fue anticipada por Amonio y Boecio, quienes arguyeron que Aristóteles, reaccionando en contra del naturalismo platónico, desarrolló una teoría de los nombres como símbolos convencionales ( $\sigma 0 ́ \mu \beta 0 \lambda o v)$ (Int. 16a3-4, 17a1-2, 24b1-3) opuestos al carácter de instrumento natural (ópyavov) que Platón les habría asignado a las unidades semánticas mínimas (Cra. 388a6-8). ${ }^{7}$ Autores como Norman Kretzmann y C.W.A. Whitaker aceptaron esta sugerencia. En particular, Whitaker le atribuyó a

\footnotetext{
${ }^{6}$ Cfr. Modrak, Language and Meaning, pp. 13, 19.

${ }^{7}$ Entre la larga lista de contribuciones a la discusión sobre el naturalismo y el convencionalismo lingüísticos en el Cra., cfr. Giorgos Anagnostopoulos, "Plato's Cratylus: The Two Theories of the Correctness of Names," The Review of Metaphysics 25 (1971): 691-736; Norman Kretzmann, "Plato on the Correctness of Names," American Philosophical Quarterly, 8/2 (1971): 126-38; Gail Fine, "Plato on Naming," Philosophical Quarterly 27/109 (1977): 289-301; Rachel, Barney, "Plato on Conventionalism," Phronesis 42/2 (1997): 143-62; y más en general los comentarios aún recientes de David Sedley, Plato's Cratylus. Cambridge (U.K.): Cambridge University Press, 2003; y Francesco Ademollo, The Cratylus of Plato: A Commentary. New York: Cambridge University Press: 2011.
} 
Aristóteles una tesis marcadamente convencionalista: el símbolo sería una pieza (token) usada de manera meramente convencional como un medio dúctil para el reconocimiento de algo. Whitaker completa esta imagen atribuyéndole a Aristóteles una teoría causal del significado, según la cual en la fijación causal de la referencia no interviene elemento epistémico alguno, como podrían ser las intenciones y las representaciones mentales o conceptos. $^{8}$

Una primera advertencia que se podría formular con relación a estas dos opciones es que en el Cratylus Platón parece mostrar que la teoría naturalista del significado y la teoría de la mente explicada en términos de un representacionismo naturalista rancio -una posición conforme a la cual la mente capta sus correlatos produciendo estrictas semejanzas de la realidad- están inescindiblemente vinculadas. Esta posible correlación entre dichas teorías hace que resulte cuanto menos controvertible -no obstante lo cual esto es lo que hacen muchos intérpretes- adjudicar a Aristóteles una explicación convencionalista sin matices del significado de los nombres (16a19, a27-28), a la manera sugerida por Boecio, y, a la vez, seguir atribuyéndole la concepción especular del pensamiento, según la cual los estados mentales que son vehículos de significado serían sólo aquellos que copian las cosas. Esta situación puede inclinar la balanza a favor de la segunda de las dos visiones mencionadas arriba, la cual, a la vez que afirma el convencionalismo lingüístico, busca prescindir de las intenciones y las representaciones. Pero esta solución puede implicar pagar un precio demasiado alto. La primera opción puede mejorarse sustancialmente si se abandona una noción rancia de representación mental y se la combina adecuadamente con el reconocimiento del impacto causal que la realidad tiene sobre el pensamiento representacional. Al menos ésta es la sugerencia que trataré de defender aquí. En síntesis, creo que podemos mantener que los nombres aristotélicos son convencionales, en la medida en que su valor semántico no depende de imitación alguna. Sin embargo, como sugerí, el significado de los nombres no es algo que Aristóteles haga depender de la asignación de una palabra a una cosa con prescindencia de toda consideración de la capacidad epistémica de los usuarios calificados. En efecto, tal asignación parece requerir, a ojos de Aristóteles, un complejo mecanismo que envuelve la identificación de estructuras de la realidad. Para poder hacer esto último, el

${ }^{8}$ Cfr. Norman Kretzmann, "Aristotle on Spoken Sound Significant by Convention," ["Spoken Sound"] en Ancient Logic and Its Modern Interpretations, John Corcoran (ed.), 3-21. Dordrecht/ Boston: Reidel, 1974, pp. 13 ss.; C. W. A Whitaker, Aristotle's De Interpretatione. Contradiction and Dialectic. [De Interpretatione] Oxford: Oxford University Press, 1996, pp. 9 ss. 
usuario del lenguaje necesita contar con las capacidades epistémicas requeridas. Si esto es así, la referencia lingüística parece depender del concepto o de cierta representación mental que una palabra expresa al nivel lingüístico. Para Aristóteles, esa representación mental tiene valor objetivo, en la medida en que representa cómo son las cosas. Éste sería el núcleo de la tesis de De Interpretatione (cfr. especialmente 16a6): las voces, que tienen un valor convencional, operan como signos de las afecciones del alma, es decir, las voces indican un contenido universalmente válido. Ese contenido es el que los humanos se forman mediante una representación mental que depende de cómo son las cosas del mundo, y de la efectiva capacidad que tenemos de captarlas representacionalmente. Interpretar esa representación mental en términos de la semejanza que sustenta aquel naturalismo rancio posiblemente ya desestimado por Platón no es una implicación que Aristóteles deba admitir por el solo hecho de que él mantenga que el significado depende de que la mente funcione representacionalmente.

Antes de comenzar a desarrollar mi argumento, quisiera presentar la organización general de este artículo. De 2. a 6.4. me concentraré en la teoría del significado en De Interpretatione; mientras que de 7. a 7.2. consideraré la teoría de la mente de De Anima (con complementos de Parva Naturalia) que coherentemente debemos suponer vinculada a aquella noción de significado. Más en detalle, en 2. esbozaré la noción de representación mental que plausiblemente puede adjudicarse a Aristóteles; en 3. y 4. examinaré pormenorizadamente De Interpretatione 16a3-8; en 5. discutiré el problema de la referencia indirecta; en 6. (y sub-apartados) trataré de aclarar la noción de nombre aristotélico. Ya en 7. intentaré desacreditar la idea de que la noción aristotélica de significado puede explicarse mediante la imaginación; en 7.1. discutiré el uso de las imágenes para inteligir, y si esto implica alguna clase de identidad entre imágenes y conceptos; en 7.2. trataré de reponer dentro de sus límites la analogía aristotélica entre intelección y senso-percepción. Por último, en 8. haré algunas observaciones finales sobre la posición que coherentemente podemos atribuir a Aristóteles en cuanto a los estados intencionales involucrados en el uso del lenguaje por parte de los animales racionales. ${ }^{9}$

\footnotetext{
${ }^{9}$ En su influyente comentario, John L. Ackrill, Aristotle's Categories and De Interpretatione. [Categories and De Interpretatione] Translated with notes, Oxford: Oxford University Press, $1970^{2}$, desarrolla una visión con la que discrepo en algunos de los tópicos mencionados aquí arriba. Para Ackrill, "There are grave weaknesses in Aristotle's theory of meaning" (id., p. 113). En cambio, según Modrak, Language and Meaning, p. 2: "Far from being inadequate, De Interpretatione 16a3-8 summarizes a theory of meaning, I shall argue, that served Aristotle well throughout of his career". Para esta autora, esa escueta explicación sobre el significado sólo puede entenderse si se contextualiza el pasaje dentro del marco de la discusión sobre lógica, ontología
} 
y psicología (cfr. Modrak, Language and Meaning, pp. 21 ss., 265-78). Nótese que una visión positiva sobre De Interpretatione de una índole semejante sólo puede sostenerse si se rechaza la opinión que transmitiera Paul Gohlke, Die Entstehung der Aristotelischen Logik, Berlin: Reimer, 1936, pp. 12, 27 (passim), para quien De Interpretatione es un tratado temprano de Aristóteles, cuyas posiciones habrían sido dejadas de lado por anticuadas (veraltet) en los escritos posteriores, lo que explicaría que De Interpretatione no sea citado en otros tratados aristotélicos. Con respecto a esta última inferencia sobre cronología relativa, Hermann Weidemann, Aristoteles, Peri Hermeneias. Übersetzt und erläutert, [Peri Hermeneias] en Aristoteles, Werke in Deutscher Übersetzung, Band 1/II. Berlin: Akademie Verlag, 2002², pp. 45 ss., advierte que la mayoría de los especialistas (incluyendo a H. Maier, Ch. Brandis y posteriormente a I. Düring y P. Moraux) son reacios a establecer cronologías relativas de los tratados aristotélicos a partir de las remisiones que se encuentran en los escritos transmitidos del estagirita. No obstante, sobre la base de otros criterios, tales como la presencia de cierto formalismo (i.e. uso de variables, cuyo punto de referencia es, obviamente, Analíticos Primeros), el mismo Weidemann (con J. M. Bocheński y V. Sainati) se inclina por datar a De Interpretatione en un período intermedio dentro del Organon, en cualquier caso anterior a los Analíticos. Contrariamente, Elio Montanari, La sezione linguistica del Peri Hermeneias di Aristotele, [Peri Hermeneias] Firenze: Olschki, 1984 (vol. I), 1988 (vol. II), cfr. vol. I, pp. 18, 142; vol. II, pp. 63, 95 (passim), vuelve a defender una datación tardía para De Interpretatione (especialmente para Int. 1-4). En vista de todo esto, parece admisible considerar De Interpretatione 1-6 como la expresión de ciertas posiciones básicas válidas incluso para la producción posterior de Aristóteles. Parece aceptable también suponer que los primeros capítulos de De Interpretatione contienen elementos doctrinarios que, en principio, no deben considerarse incompatibles con otros tratados posteriores y quizá más complejos. La mayoría de los especialistas consideran, además, que De Interpretatione 1-6 forma una cierta unidad temática que claramente responde al programa trazado en 16a1-2. En cuanto a la importancia general del tratado, Kretzmann, "Spoken Sound," p. 3, exageró tal vez al calificar el pasaje de Int. 16a3-8 como el texto más influyente en la historia de la semántica. Imagino que un juicio así puede justificarse, sin embargo, si, con Ernst Kapp, Greek Foundations of Traditional Logic, New York: Columbia University Press, 1942, p. 49, admitimos que: "If one may call the source of endless trouble a foundation, we could say that this chapter [i.e. Int. 1] has become the foundation of a large part of the logical literature of all times". Ciertamente, Kapp enfoca De Interpretatione más bien desde el punto de vista de la distinción entre lógica y gramática. En lo que concierne al programa de De Interpretatione, Terence H. Irwin, "Aristotle's Concept of Signification," ["Signification"] en Language and Logos: Studies in Ancient Philosophy (Festschrift G. Vlastos), Malcolm Schofield and Martha Nussbaum (eds.), 241-66. Cambridge: Cambridge University Press, 1982, puso algunos reparos a la pretensión de alinear este tratado aristotélico dentro de la filosofía del lenguaje contemporánea, y propone disociar la teoría de Aristóteles sobre la "signification" (que involucraría al pensamiento y a las cosas extramentales) respecto de las teorías contemporáneas acerca del "meaning" (que se clausurarían en la discusión sobre el significado lingüístico). Irwin aproxima la posición del estagirita a las teorías realistas del esencialismo contemporáneo: "An [Aristotelian] inquiry into the signification of words is not concerned with sense [...] but with the discovery of the real properties there are and their relation to words». Cfr. Irwin, "Signification," p. 265. Similarmente, Robert Bolton, "Essentialism and Semantic Theory in Aristotle: Posterior Analytics, II, 7-10," The Philosophical Review 85 (1976): 514-44, pp. 541 s.; y Charles, Meaning and Essence, pp. 4-19, 161-175, 348-372. Por otras razones sistemáticas, Jean-Louis Hudry, "Aristotle on Meaning," Archiv für Geschichte der Philosophie 93 (2011): 253-80, rechaza que sea justificado hablar de una "semántica" en Aristóteles. De otra parte, Eduardo Rabossi, "Lenguaje, pensamiento y realidad. Peri Hermeneias 16a," Revista Latinoamericana de Filosofia VIII/2 (1982): 169-80, sugirió que De Interpretatione anticipa las teorías anti-realistas del significado. Por último, mientras que Modrak, Language and Meaning, insistió en la afinidad que guardaría la teoría aristotélica del significado con enfoques recientes que lo explican en términos de una propiedad intencional, Whitaker, De Interpretatione, pp. 6 s., sostuvo que De Interpretatione 1-6 debe entenderse más restringidamente como una investigación preliminar al tratamiento de la aserción contradictoria, la cual es una herramienta 


\section{Aristóteles y el representacionismo}

En este apartado me propongo mostrar que no forma parte de una teoría moderadamente representacionista, como la que le atribuiré a Aristóteles, adjudicar a los usuarios del lenguaje una misma imagen mental que ellos deberían compartir al usar palabras sinónimas. Mi llamado de atención al respecto busca concentrarse, por un lado, en la controvertida explicación de los conceptos a través de imágenes. Por otro lado, quiero también advertir que hay una consecuencia internista que deben afrontar quienes interpretan de esa manera la semántica aristotélica; tal es la idea de que las representaciones mentales conforman una especie de lenguaje del pensamiento, del cual los signos lingüísticos serían externalizaciones. Una teoría de ese tipo se compromete con la suposición de que los contenidos mentales determinan suficientemente la referencia de las palabras, y además con que entre las esferas del pensamiento y del lenguaje hay alguna clase de correspondencia, la cual guarda relación con la mayor o menor complejidad de las respectivas estructuras de cada una de esas dos esferas. En este último aspecto, tales teorías suelen tener una impronta reduccionista: formaciones lingüísticas y conceptuales complejas se reducen a otras más simples, básicas o elementales.

Frecuentemente, la posición de Aristóteles ha sido adoptada por los teóricos internistas como uno de sus primeros antecedentes históricos. Sin embargo, la posición que puede atribuirse a Aristóteles a partir de la lectura de los textos relevantes de De Interpretatione y De Anima no parece sustentar dicha adopción, ya que Aristóteles no adquiere los compromisos que son decisivos para poder atribuirle una teoría figurativa y una explicación internista del significado. Tampoco parece admitir un cierto representacionismo que atribuye a las representaciones mentales la capacidad de fijar suficientemente el significado. Por empezar, a pesar de lo que puede parecer, no hay

principal de la refutación dialéctica. Sobre otras interpretaciones de De Interpretatione (antiguas, medievales y de los Siglos XIX y XX), incluyendo el sentido que hay que dar al título, y sobre la ubicación de este tratado dentro del Organon, cfr. Weidemann, Peri Hermeneias, pp. 41-87; Whitaker, De Interpretatione, pp. 1 ss.; Lambertus Marie De Rijk, Aristotle: Semantics and Ontology. Volume I Semantics and Ontology, [Semantics] Leiden: Brill, 2002, pp. 190-2 (quien toma el título del tratado como "expresión de un pensamiento"). Para un estudio detallado de la denominada "sección lingüística" (De Interpretatione 1-6), véase Montanari Peri Hermeneias (vol. I). Para un estudio general en castellano, cfr. Jaime Araos, La filosofía aristotélica del lenguaje, Pamplona: Eunsa, 1999. Mucho más de lo que puede reconocer una u otra nota al pie ocasional, manifiesto aquí mi deuda con la Tesis Doctoral de Eduardo H. Mombello, Aristóteles, Ser y Decir: Una reconstrucción de la doctrina de la referencia en la teoría del lenguaje y de la ciencia (Universidad Nacional de Córdoba, 2011, inédita). 
suficiente base textual para suponer que lo que determina la referencia de las palabras, según Aristóteles, sea una imagen mental o una unidad conceptual que corresponda a la realidad externa o cualquier clase de representación. La posición de Aristóteles en lo que respecta a la fijación de la referencia de las palabras parece ser fruto de una estrategia diferente para explicar el significado: lo que explica la referencia de las palabras y el carácter representacional del pensamiento es simplemente cómo son las cosas externas, y, obviamente de manera derivada, nuestra representación mental, pero ésta sólo en la medida en que tiene la capacidad de captar cómo son las cosas. Dicho brevemente, para Aristóteles la fijación de la referencia lingüística depende, en última instancia, de que ciertas palabras expresen a través de su significado la constitución o estructura de las cosas, de manera tal que para conocer el significado de una palabra no puede prescindirse de conocer cómo son los objetos designados por esa palabra, lo que obviamente envuelve una investigación que no tiene un carácter lingüístico ni puede llevarse a cabo implementando alguna clase de escaneo mental que nos permitiera acceder a la imagen de la cosa externa supuestamente fijada en la mente. Sin embargo, la advertencia anterior no implica que las representaciones mentales no jueguen ningún rol en la determinación del significado; más bien, la tesis es que su rol es secundario, en el sentido de que lo que aprendemos considerando nuestras representaciones mentales depende del potencial cognoscitivo de estas últimas, lo cual, a su vez, quiere decir que las representaciones mentales sólo interesan, en este aspecto, en virtud de que ellas captan cómo son las cosas externas. Una teoría de este tipo tiene, entonces, un rasgo externista y epistémico; y para ella es crucial mantener la prioridad ontológica y epistémica del mundo ante la mente.

Desde un punto de vista histórico, la explicación dada por Amonio al sentido del título del tratado conocido a través de su traducción latina como De Interpretatione, interpretación según la cual el título indica que la oración declarativa o aserción es aquella mediante la cual cobra expresión el pensamiento (animae cognitiones), parece poner de manifiesto el enraizamiento de esta discusión en la misma aclaración de la intención y del contenido del tratado, y a la vez mostrar que ya desde Amonio este tratado ha sido leído, si se permite el anacronismo, como un proyecto de alguna manera emparentado con el Mind Reading, en la medida en que son precisamente las representaciones mentales lo que se supone que Aristóteles intenta allí investigar a través de la expresión lingüística. ${ }^{10}$

${ }^{10}$ Amonio, In Aristotelis De Interpretatione commentarius, A. Busse (ed.), Commentaria in Aristotelem Graeca IV. 5. Berlin: Reimer, 1897, pp. 5, 18 s. Kapp, Greek Foundations, pp. 47 ss., señala que el sentido dado al título del tratado ("on the expression of thoughts in speech") es 
Algo básicamente coincidente con esta variante de representacionismo internista que casi unánimemente se ha atribuido a Aristóteles es lo que Hilary Putnam rechaza bajo lo que él individualiza como tres aspectos de una teoría del significado concebida según el "modelo aristotélico" de De Interpretatione. ${ }^{11}$ Habría que anticipar que ni Aristóteles ni Putnam rechazan sin más las representaciones mentales como explicativas del significado; pero a ello habría que añadir también que con sólo aceptar cierto rol para las representaciones mentales no alcanza, ciertamente, para comprometerse con el internismo, que es la tesis sobre el significado y la mente que se atribuye comúnmente a Aristóteles. Recordemos cuál es tal vez la intención básica de la división de la labor lingüística propuesta por Putnam: no identificar los problemas de la referencia y los de la representación mental. ${ }^{12}$ Un punto central de esta división de labores, con la cual creo que la posición de Aristóteles es consistente, desemboca en una tesis externista y de tinte epistémico sobre el significado. Esa tesis mantiene que la referencia de las palabras se fija a través de mecanismos lingüísticos y convencionales, y que, en cierto sentido, de tal fijación de la referencia no son responsables las representaciones mentales, ya que cuando hablamos del significado, cuando traducimos o aclaramos el significado de una palabra, no hablamos de las representaciones mentales. Pero esto no quiere decir que no haya ninguna clase de representación interviniendo en ese proceso. La contribución que, en una posición externista, puede adjudicarse a las representaciones mentales en relación con la determinación del significado de las palabras es, más bien, de carácter epistémico, ya que las representaciones o conceptos contienen precisamente lo que sabemos no acerca de cómo se usan las palabras, sino más bien aquello que sabemos acerca de cómo es el mundo al que las palabras refieren. Desde este último punto de vista, los problemas acerca del significado no se saldan mediante una discusión acerca de las palabras ni acerca de las representaciones mentales que asociamos convencionalmente a los fonemas de una determinada lengua, sino mediante una discusión de otro orden acerca del conocimiento de las cosas externas referidas por las palabras. En este marco, es bastante plausible suponer que Aristóteles aceptaría la sugerencia de Putnam sobre el predominio que, en la

engañoso, y añade que los temas de Int. (enumerados en 16a1-2) envuelven tanto nociones de gramática (sustantivo, verbo) como de la silogística aristotélica (afirmación, negación, proposición o enunciado y discurso). Kapp enfatiza que la restricción de Int. al estudio del enunciado declarativo ubica al tratado en la tradición de la lógica moderna.

${ }^{11}$ Hilary Putnam, "Meaning, Other People, and the World," ["Meaning"] en Representation and Reality, pp. 19-41, Cambridge (Massachusetts): The MIT Press, 1988.

${ }^{12}$ Cfr. Putnam, “Meaning,” pp. 22-26. 
división del trabajo lingüístico, adquiere el conocimiento de los expertos, es decir, personas que conocen tan bien como los legos el significado, pero que, en su condición de expertos -idealmente, quienes poseen epistéme y demostraciones, para Aristóteles-, pueden conocer más y mejor cómo son ciertas cosas del mundo. ${ }^{13}$

Sobre esto último, quizá debería apresurarme a aclarar un punto que puede despertar dudas. Creo que cuando Aristóteles afirma que a las mismas cosas corresponden las mismas representaciones mentales (Int. 16a6-8) no está pensando en meras propiedades fenoménicas de las cosas, sino más bien en lo que llamé estructuras. Esto no se afirma explícitamente en el texto aristotélico, pero es crucial para mantener una interpretación de De Interpretatione que sea consistente con otras suposiciones centrales acerca de la relación entre nombres, definición y demostración que se encuentran en Analíticos Segundos. Al hablar de propiedades fenoménicas me refiero a cosas tales como el punto de ebullición del agua, la caducidad de las hojas del olmo, o la clase de tejido orgánico humano. Ejemplos aristotélicos estándar de tales propiedades son el eclipse o las fases lunares y el trueno. Ninguna de esas propiedades son estructuras profundas de las cosas -del tipo de las propiedades esenciales y necesarias aristotélicas-, sino que podemos pensar que esas propiedades dependen de las estructuras -a la manera en que las propiedades accidentales aristotélicas dependen (causalmente) de las esenciales y necesarias-. Podemos aplicar a Aristóteles, en este sentido, la conocida hipótesis de Putnam: podría suceder que con respecto a las propiedades fenoménicas de dos cosas particulares las personas compartieran algunas representaciones mentales; pero si se averiguara que las estructuras de esas cosas son diferentes entre sí, entonces los conceptos que tendrían esas personas tampoco podrían ser los mismos. Estoy suponiendo aquí que los conceptos aristotélicos tienen un carácter eminentemente epistémico, en la medida en que no son cualquier clase de creencias, sino que están sometidos al control del mundo -o dicho en otra jerga actual, ellos responden a cómo es el mundo-, precisamente en la medida en que los conceptos realizan idealmente la capacidad mental de captar las estructuras de las cosas.

Difícilmente puede mantenerse que las creencias aristotélicas no versen acerca del mundo ni estén sujetas a ningún control, como si Aristóteles aceptara que cualquier

\footnotetext{
${ }^{13}$ Imagino que Aristóteles se rendiría ante la elocuencia de la aseveración de Putnam, "Meaning," p. 25: "Looking inside the brain for the reference of our words is, at least in cases of the kind we have been discussing, just looking in the wrong place".
} 
persona puede creer lo que se le antoja acerca de un determinado episodio y reclamar que eso es una creencia genuina. Sin embargo, hay una diferencia elemental: una proposición demostrada dentro de una ciencia aristotélica no tiene el mismo valor epistémico que una creencia no integrada a una demostración. Una proposición demostrada debe expresar las estructuras causales de las cosas; una creencia, incluso siendo verdadera, no lo hace necesariamente. Esto desembocaría en la siguiente situación: dos personas pueden tener la misma creencia acerca de dos muestras determinadas, y creer que esas muestras pertenecen a la misma clase. Al nivel del concepto, sin embargo, en una situación ideal, es decir, si se contara con una explicación acerca del comportamiento de esas muestras y se estableciera que son específicamente diferentes, esas dos personas no podrían tener el mismo concepto. Para Aristóteles, sólo al nivel del conocimiento que expresa el concepto (la aprehensión intelectual de la forma de una cosa) y la demostración (la explicación causal del comportamiento de una cosa) somos capaces de distinguir fases lunares respecto de eclipses. Así, antes de alcanzar una explicación causal de cada uno de esos dos distintos fenómenos, las dos personas que hemos imaginado podrían haber tenido las mismas creencias, a pesar de que, en los hechos, sus creencias se refirieran, en realidad, a cosas diferentes.

\subsection{Significado y representaciones mentales}

La posición de Aristóteles se caracteriza por una notable parquedad en cuanto a las especulaciones acerca de la existencia de alguna clase de código o lengua mental hecha de imágenes, a lo cual accederíamos a través de la externalización que conllevaría el lenguaje. Pero esa parquedad no es meramente fruto de cierto innegable desarrollo rudimentario de la psicología aristotélica, sino que, más bien, en este aspecto, esa parquedad es resultado del hecho de que la semántica de Aristóteles no se apoya en la suposición de una lengua mental ni apela a consideraciones sobre la correspondencia y la identidad entre unidades semánticas y unidades mentales, como sucede en un programa mentalista. De tal manera, hay un tópico concreto del modelo aristotélico rechazado por Putnam que, aunque pueda parecer sorprendente, no creo que corresponda a la posición de Aristóteles: Aristóteles no se ocupa de la representación mental cuando en De Interpretatione considera qué es lo que convierte a un signo o a una voz en significativa. Contrariamente a lo que supone no sólo Putnam, sino también un cierto de número de aristotelistas, a Aristóteles no puede adjudicársele fácilmente la tesis clásica del 
representacionismo, según la cual la representación mental constituye el contenido semántico (el significado) de un término y determina su referencia al mundo.

Los aristotelistas suelen llamar la atención sobre algunos pasajes de los Parva Naturalia al discutir la atribución de representacionismo a Aristóteles. En De Memoria I 1, 450a25-451a17, la cuestión que se plantea es qué recuerda una persona cuando recuerda algo, ¿el objeto externo ausente - todo lo que se recuerda es algo que ya no está

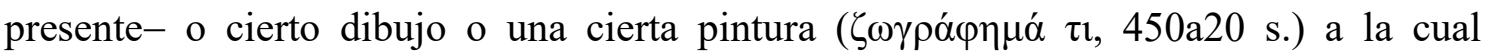
corresponde una representación o un pensamiento presente en la mente? Una interesante lectura de este texto es la de Hermann Weidemann. ${ }^{14}$ Él discute si es lícito adjudicar a Aristóteles (particularmente en De Interpretatione) una variante bastante extrema de representacionismo (no el representacionismo moderado que le he adjudicado aquí), según la cual los correlatos propios y primarios de nuestros pensamientos y de nuestro lenguaje serían las representaciones mentales, mediante las cuales hacemos referencia al mundo externo. En De Memoria et Reminiscentia 1, Aristóteles señala que una pintura o imagen mental (cuya posesión constituye la memoria, 450a30) tiene un valor doble: (a) por sí misma es precisamente una pintura que es susceptible de ser contemplada en cuanto es una pintura; pero (b) en relación con otra cosa es una representación de algo diferente, y en esta consideración es un cỉkóv (450b21 s., b23, b27, b30, 451a2) o imagen de lo que ella representa. Según (b), la pintura o imagen tiene un papel instrumental en la representación, ya que es aquel medio con cuya ayuda nos representamos (recordamos o pensamos) algo, que es propiamente lo recordado, pero que no es la pintura como tal.

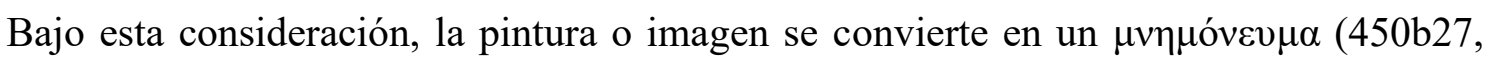
451a2), una pieza que sirve para recordar algo, similarmente a un objeto que se usa como un "recordatorio" (en la traducción de Bernabé Pajares, que parece influida por la versión inglesa de R. Sorabji, "reminder") de otra cosa. ${ }^{15}$ La respuesta final de Aristóteles refina la expresión de 450a30: la memoria y el recordar se explican por la posesión de una

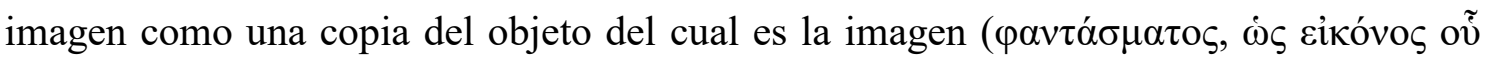

${ }^{14}$ Hermann Weidemann, "War Aristoteles ein Repräsentationalist," ["Repräsentationalist"] en Ancient and Medieval Theories of Intentionality, Dominik Perler (ed.), 97-104, Leiden: Brill, 2001. Para un comentario de De Memoria 1, cfr. R. A. H. King, Aristoteles, De Memoria et Reminiscentia. Übersetzt und erläutert, en Aristoteles, Werke in deutscher Ubersetzung, Bd. 14, Parva naturalia, Teil III, Berlin: Akademie-Verlag, 2004, pp. 79-109.

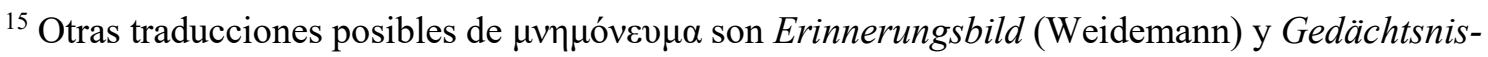
gehalt (King). No puedo entrar aquí en el detalle del proceso psíquico involucrado ni en otros tecnicismos vinculados a su vocabulario. 


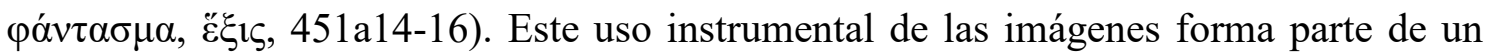
representacionismo moderado que podemos adjudicar a la teoría aristotélica de la memoria.

La conclusión que puede extraerse sobre el representacionismo que es atribuible a Aristóteles sobre la base de De Memoria et Reminiscentia sugiere que Aristóteles defiende claramente la tesis de la instrumentalidad necesaria de las representaciones (para el caso de la memoria en el texto que hemos considerado); pero la posibilidad de producir un contenido mental del tipo de la memoria depende de que utilicemos una imagen como medio para referir la imagen a aquello de lo cual ella es precisamente una imagen memorativa, i.e. de que utilicemos un determinado contenido que tenemos en la mente como imagen o como representante (memorativo) de otra cosa. Se trata, entonces, de un representacionismo, en la medida en que la memoria depende del uso de las representaciones; pero es un representacionismo moderado porque en él no se confunde medio con objeto de la memoria, ni representante con representado.

Un objetivo principal de este artículo es discutir esta cuestión en dos sedes relacionadas: semántica y psicología. Se trata de discutir, pues, por un lado, si De Interpretatione se compromete con que los pensamientos son el referente primario del lenguaje (como parece sugerirlo 16a6-7, al considerar que las voces son primeramente signos de los pensamientos), y si esto implica un representacionismo extremo (infra 3.5.). ${ }^{16}$ Por otro lado, se trata de considerar si la teoría general de la imaginación, como la capacidad de formarse imágenes, y la relación de las imágenes con el intelecto son coherentes con los lineamientos representacionistas moderados contenidos en la descripción de la memoria (infra 7).

\footnotetext{
${ }^{16}$ La respuesta de Weidemann, "Repräsentationalist," p. 102, a esta cuestión es negativa y paralela a su interpretación del uso de imágenes en la memoria: los pensamientos son, como las imágenes en el caso de la memoria, primeramente referidos por el lenguaje en cuanto que medios o instrumentos, pues ellos son semejanzas de las cosas, pero sin que ello implique que los pensamientos sean los objetos mismos de la referencia lingüística. Esta plausible interpretación tiene aún que explicar, sin embargo, en qué sentido los pensamientos son semejanzas (Int. ó es un imagen o una pintura de un objeto del recuerdo, mientras que la traslación de ese vocabulario pictórico a la teoría de los conceptos y el significado puede ser problemática. Discuto esto a continuación desde el punto de vista de un convencionalismo lingüístico moderado que atribuyo a Aristóteles. Comparto aquí la visión general de Weidemann: "Mentale Reprasentationen lassen uns nach Aristoteles in Gedanken bei den Dingen sein, die sie repräsentieren, und ermöglichen damit die intentionale Ausrichtung unseres Denkens und Sprechens auf die Welt." (Id., "Repräsentionalist", p. 104).
} 
Antes de entrar en el detalle de la interpretación textual, quisiera tratar de redondear la discusión teórica sobre la posición general aristotélica. Como sugerí, Aristóteles afirma que el lenguaje ancla en el mundo, y que no lo hace exento de una carga normativa proveniente de nuestra comprensión de las cosas del mundo. Esto último involucra, obviamente, nuestros conceptos o representaciones mentales, y en este sentido muy restringido puede adjudicarse a Aristóteles una tesis representacionista básica: las palabras se refieren a las cosas externas en la medida en que tenemos la capacidad mental de captar las cosas a través de conceptos. Pero lo que hace Aristóteles en De Interpretatione es distinto de lo que habría que esperar si él fuera un filósofo que los representacionistas contemporáneos podrían reclamar como uno de sus antecesores. En lugar de entrar en intrincadas investigaciones acerca de las posibles unidades mentales que, por sí mismas, pretenderían explicar la referencia de los signos que a tales representaciones mentales supuestamente deberían corresponder -un proyecto que ya por el muy rudimentario nivel de desarrollo del conocimiento de la cognición humana difícilmente podría haber atraído a Aristóteles-, él se conforma con enfatizar un convencionalismo lingüístico moderado, es decir, una tesis que recurre al uso convencional de ciertos signos que se toman como representaciones de las cosas externas. El convencionalismo que suscribe Aristóteles al caracterizar un nombre -es decir, lo que es para él la unidad semántica elemental- como una voz significativa por convención (Int. 16a19) implica que no hay nada natural en el signo que explique la referencia. Similarmente, la representación mental o el concepto, con respecto al cual ese nombre funciona como un símbolo o contraparte (16a3-4), no explica la referencia en virtud de algún rasgo mentalista. Sobre esta base querría hacer, entonces, dos sugerencias. En primer lugar, para Aristóteles la mente (o más precisamente el intelecto que capta las formas de las cosas) no representa el mundo en virtud de que lo figure a través de imágenes mentales -ni posiblemente mediante alguna otra clase de unidad mental-. ${ }^{17}$ En segundo lugar, las representaciones mentales no pueden explicar el significado de las palabras sin el concurso del uso y la comprensión de los usuarios del lenguaje.

En este último sentido, es preciso acentuar que el aristotélico es un convencionalismo moderado, pues comparte la idea de que los seres humanos tienen los mismos conceptos de una realidad objetiva estable en su estructura. Aristóteles sostiene, en efecto, que las

${ }^{17}$ Una suposición crucial de las teorías internistas o mentalistas del significado consiste en que debe haber una correspondencia entre unidades lingüísticas y unidades mentales o conceptuales. 
representaciones mentales o afecciones del alma son las mismas para todos los seres humanos, en la medida en que tales afecciones representan la misma realidad extramental (16a6-7). Como trataré de mostrar, creo que este enfoque que estoy atribuyéndole a Aristóteles explica el programa de De Interpretatione 1-6, que desarrolla una semántica hasta cierto punto independiente de otro programa de discusión: el que considera las representaciones mentales en sus distintas facultades, como se encuentra en De Anima. Una distinción de programas y estrategias de ese tipo es lo que puede justificar que $D e$ Interpretatione 16a9 indique que corresponde a "otro tratado" ocuparse de la manera en que las afecciones del alma representan las cosas. Al efectuar este deslinde, Aristóteles parece sugerir que el significado se explica en una sede distinta de la psicología, ya que el significado tiene que ver con la comprensión y el dominio del lenguaje, con normas aceptadas por los hablantes, y obviamente con la capacidad de vincular sonidos y grafemas convencionales con representaciones mentales en un contexto no solipsista ni introspectivo -como es el del mentalismo, que considera suficientes a las representaciones para determinar el significado-, sino, en cambio, en un contexto de interacción social con otros hablantes y de carácter externista, es decir, un contexto en el cual los hablantes comparten un conjunto de normas semánticas y de prácticas epistémicas, las cuales controlan y viabilizan el uso y la aplicación de las palabras. La impronta epistémica de la teoría aristotélica del significado es un componente de su mismo enfoque normativo, ya que, para Aristóteles, en el uso y la aplicación de las palabras apuntamos centralmente a la corrección: distinguimos aplicaciones y usos correctos de otros incorrectos. Esta práctica elemental implica que los hablantes conocen los criterios que regulan el uso correcto -o, en su defecto, descansan en el conocimiento experto para acceder a tales criterios-. Pero, como anticipé, tales criterios no se clausuran en un dominio autónomo del lenguaje; por el contrario, afirmar que los criterios que regulan la corrección de los nombres descansan en parámetros epistémicos implica suponer que, para Aristóteles, tales criterios se apoyan en el conocimiento de la estructura de las cosas; e implica también que usar correctamente una palabra guarda relación con tener las creencias admisibles y consistentes con las teorías científicas disponibles que mejor explican las cosas que designamos con esas palabras. Dicho brevemente, en el dominio de una lengua por parte de los usuarios está implícito el manejo de criterios objetivos elaborados idealmente a través de una teoría científica por parte de los agentes epistémicos. 


\section{De Interpretatione 16a3-8: texto y traducción}

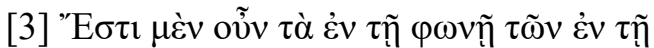
$\psi v \chi \tilde{\eta} \pi \alpha \theta \eta-$

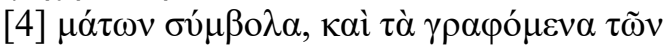
$\dot{\varepsilon} \vee \tau \tilde{\eta} \varphi \omega v \tilde{n}$.

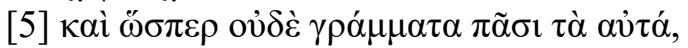

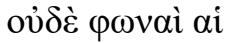

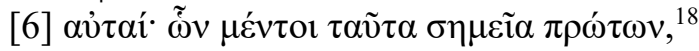
$\tau \alpha \hat{\tau} \tau \grave{\alpha} \pi \tilde{\alpha} \sigma \mathrm{l} \pi \alpha-$

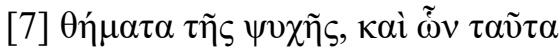

ó $\mu \mathrm{o} \omega \dot{\omega} \mu \alpha \alpha \alpha \pi \alpha \dot{\gamma} \gamma \mu \alpha \tau \alpha$

[8]
[3] $\{\mathrm{A}\}\{\mathrm{a}\}$ Ahora bien, (i) lo que hay en la voz es símbolo $(\sigma 0 \dot{\mu} \beta \mathrm{o} \lambda \alpha)$ de (ii) las afecciones que se dan en el alma, [4] $\{b\}$ y (i) lo escrito $<$ es símbolo $>$ de (ii) lo que se da en la voz. [5] $\{\mathrm{B}\}\{\mathrm{a}\}$ Y tal como (i) las letras no son las mismas para todos, tampoco

(ii) las voces son las [6] mismas. $\{b\}$ Mientras que (iii) aquellas cosas de las cuales (ii) éstas son primeramente signos $(\sigma \eta \mu \varepsilon i \alpha)$, (iii) las afecciones del alma, son las mismas para todos [7]; \{c $\}$ y también (iv) de aquellas cosas de las cuales ${ }^{19}$ éstas ${ }^{20}$ son semejanzas (ómotó $\mu \alpha \tau \alpha),{ }^{21}$ (iv) las cosas, [8] son, luego, las mismas. (Mi traducción). ${ }^{22}$

Para comenzar, intentemos una aclaración elemental del pasaje. Desde un punto de vista temático, el pasaje es relativamente simple. En $\{\mathrm{A}\}$, Aristóteles trata la interrelación de tres de los cuatro artículos que aquí introduce, los cuales se pueden simplificar reduciéndolos a dos: lenguaje y pensamiento; mientras que en $\{\mathrm{B}\}$ se halla en el trasfondo la oposición entre naturaleza y convención. En $\{B\}$, Aristóteles considera de qué manera se relacionan los tres ítems introducidos en $\{A\}$. En $\{B\}(c)$ su intención es destacar el vínculo que mantienen los dos órdenes anteriores (lenguaje y pensamiento) con el tercero y fundamental, la realidad extramental. El tema central del pasaje parece ser, entonces, la relación entre lenguaje, pensamiento y realidad, ${ }^{23}$ que se establece de tres maneras. Los

${ }^{18}$ Adoptando el texto oxoniense de la edición de L. Minio-Paluello. Sobre el genitivo $\pi \rho \omega ́ \tau \omega v$ con matiz adverbial, cfr. infra 5. Ésta es la edición con la cual he trabajado en el presente artículo, comparándola en algunos casos con la más reciente de Hermann Weidemann, Aristotelis, De Interpretatione (ПEPI EPMHNEIA $\Sigma$ ), recognovit, Bibliotheca Teubneriana, Berlin/Boston: De Gruyter, 2014.

${ }^{19}$ Se trata de las $\pi \rho \alpha ́ \gamma \mu \alpha \tau \alpha:$ cosas reales o hechos.

${ }^{20}$ Las afecciones del alma.

${ }^{21}$ En 16a6-8, Aristóteles apunta a establecer la siguiente relación: las voces, cambiantes y convencionales, son signos de los pensamientos, mientras que éstos son semejanzas de las cosas externas, y ambos ítems, pensamientos y cosas externas, son incambiables $\mathrm{y}$, en un cierto sentido, naturales.

${ }^{22}$ Para discusiones detalladas del pasaje, cfr. Weidemann, Peri Hermeneias, pp. 142 ss.; Montanari, Peri Hermeneias (vol. II).

${ }^{23}$ En contra de la opinión de Kretzmann, "Spoken Sound," pp. 4 s.; para una discusión cfr. Modrak, Language and Meaning, pp. 15 ss. 
grafemas son símbolos de fonemas; éstos, a su vez, son símbolos (16a3) -aunque también signos, en 16a6- de las afecciones del alma, y éstas últimas, por su parte, son semejanzas de las cosas. Los ítems señalados como (i) y (ii) son lingüísticos y convencionales ("no son los mismos para todos"), lo que hace suponer que Aristóteles está pensando aquí exclusivamente, más bien que especialmente, en el lenguaje articulado. ${ }^{24}$ Difícilmente pueda ser de otra manera, puesto que las voces se relacionan con las afecciones del alma, las cuales, ya por su solo carácter de operar como semejanzas de las cosas, poseen una fuerza representacional, que Aristóteles no concederá que pueden alcanzar las bestias en su propia actividad mental y de producción de sonidos. En $\{\mathrm{B}\}(\mathrm{b})$ Aristóteles contrasta ( $\mu \varepsilon ́ v \tau o 1,16 a 6)$ la convención lingüística con la objetividad y universalidad que caracterizan la manera según la cual el pensamiento se relaciona con la realidad. ${ }^{25}$ En 16a6, la cualificación de la voz (que está aquí por el lenguaje en general) como signo tiene el propósito de señalar que, en virtud del vínculo entre lenguaje y pensamiento, la voz adquiere el valor objetivo y universal que es característico del aspecto semántico del lenguaje humano. Aristóteles elegiría signo, entonces, para indicar aquella cualificación del lenguaje que convierte a las voces humanas en vehículos semánticos como consecuencia de la relación que las palabras guardan con las afecciones del alma (primariamente aquí conceptos) cuando él busca destacar tanto la objetividad que pertenece a las voces significativas y a los conceptos mentales como también la dependencia causal del lenguaje respecto del pensamiento. En cambio, Aristóteles elegiría símbolo para el caso en que entre esos mismos dos ítems (lenguaje y pensamiento o fonemas y grafemas) hay una relación de contraseña por la cual la voz sirve para identificar un pensamiento que es su contraparte.

\footnotetext{
${ }^{24}$ Polansky y Kuczewski, "Speech and Thought,", p. 52 n. 5, hacen, en cambio, la sugerencia que aquí intento rectificar.

${ }^{25}$ Es fuerte la tentación de leer esto en línea con la distición fregeana: "Die Vorstellung unterscheidet sich dadurch wesentlich von dem Sinne eines Zeichens, welcher gemeinsames Eigentum von vielen sein kann und also nicht Teil oder Modus der Einzelseele ist [...]." Gottlob Frege, "Über Sinn und Bedeutung," Zeitschrift für Philosophie und philosophische Kritik 100 (N.S.) (1892): 25-60, p. 29 (citado según la paginación original en la reed. en Gottlob Frege, Funktion, Begriff, Bedeutung, Günther Patzig (ed.), pp. 40-65, Göttingen: Vandenhoeck \& Ruprecht, 19947). Entre los aristotelistas, Michael Wedin, Mind and Imagination in Aristotle, [Mind and Imagination] New Haven and London: Yale University Press, 1998, p. 134, insiste con razón en que los conceptos aristotélicos no pueden ser imágenes en virtud de que los primeros son universales y combinables en juicios verdaderos o falsos. Para otros aspectos de una posible comparación entre Aristóteles y Frege, cfr. Weidemann, Peri Hermeneias, pp. 150 s.
} 
Quisiera añadir tres breves notas textuales y concernientes a la traducción de la línea $16 \mathrm{~b} 7$.

En 16b7, el pronombre relativo $\tilde{\omega} v$ refiere a las afecciones del alma, como Aristóteles lo explicita a través de una aposición en 16a7. Con J. Magee, tomo $\pi \alpha \theta \eta \dot{\eta} \mu \alpha \tau \alpha \tau \tilde{\eta} \varsigma \psi v \chi \tilde{\eta} \varsigma$, en 16a7, como aposición, aunque sin admitir con ello otros aspectos de su lectura; en especial, no encuentro en el pasaje una justificación para poner mayor énfasis en que haya un compromiso atomista con elementos psíquicos correspondientes a los elementos lingüísticos (sujetos y predicados). ${ }^{26} \mathrm{Mi}$ propia lectura de $16 \mathrm{a} 6-7$ coincide con la que Weidemann llama tradicional (identificada por él como 3b) y que él mismo prefiere; no obstante, me separo de la indistinción que los tradicionalistas han querido establecer entre signo y símbolo (infra 4.).

Con $\tau \alpha \tilde{v} \tau \alpha$ en $16 \mathrm{~b} 7$ se remite a $\varphi \omega v \alpha i ̀$ en $16 \mathrm{a} 5$ (el neutro puede explicarse por

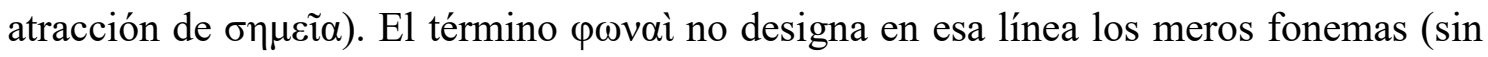

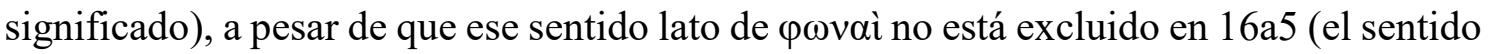
lato de voz corresponde a la definición dada en Historia Animalium IV 9, 535a28-31). No

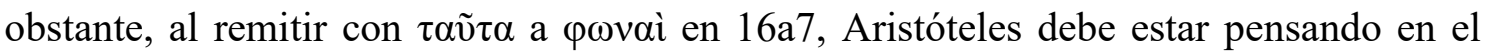
sentido específico de voz significativa, que él define en 16a19-21. Es decir, la remisión

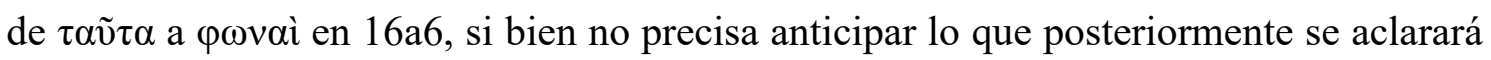
como un nombre aristotélico (16a19; aquí infra 6.3.), es suficientemente amplio como para cubrir tanto el mero aspecto fonético (dominante tal vez en 16a5, donde pwvaì tiene como contraparte $\gamma \rho \alpha ́ \mu \mu \alpha \tau \alpha$, es decir, grafemas o letras escritas) como también el más técnico y propiamente semántico de nombre, puesto que propiamente es un nombre, y no un mero fonema, aquello que puede ser signo de un pensamiento (que es el tema de 16a6). Sin embargo, el sentido lato de $\varphi \omega v \eta ́$ no está excluido de 16a6 ya que lo que él pretende destacar allí es la contraposición entre, por un lado, el aspecto variable de un idioma (en cuanto a sus letras y fonemas) y, por otro, el carácter invariable del lenguaje (los significados). ${ }^{27}$

${ }^{26}$ J. Magee, Boethius on Signification and Mind, Leiden/New York/Kopenhagen/Köln: Brill, 1989, p. 29. A favor del compromiso atomista mencionado está Montanari, Peri Hermeneias, vol. II, p. 45; para una discusión, cfr. Weidemann, Peri Hermeneias, pp. 144 ss.

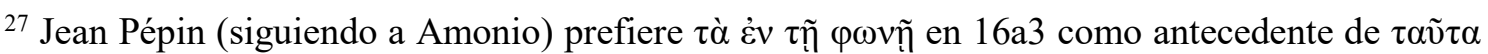
en 16a6. Pero si (más allá de que ese antecedente está más lejos de lo habitual) no hay una distinción relevante entre $\tau \grave{\alpha} \dot{\varepsilon} v \tau \tilde{\eta}$ $\varphi \omega v \tilde{n}$ y $\varphi \omega v \alpha \grave{\text {, }}$, esto no conlleva ninguna modificación importante. Cfr. Jean Pépin, " $\Sigma$ YMBO $\Lambda$ A, $\Sigma$ EMEIA, 'OMOIOMATA. A propòs de De

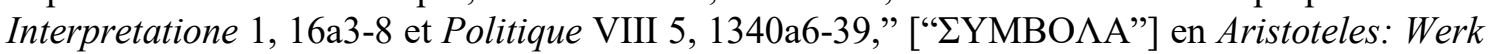
und Wirkung, Band I, Jürgen Wiesner (ed.), 22-44. Berlin: De Gruyter, 1985, p. 34 n. 39. 
Por último, en $16 \mathrm{~b} 7$ la partícula $\eta ̋ \delta \eta$ puede admitir un matiz inferencial que es posible que esté presente también en textos como el de Metaphysica Z 8, 1034a5 (pace Frede y Patzig, quienes lo traducen por “dann" y explican como una leichte Schlussfolgerung). ${ }^{28}$

\section{Signo y simbolo}

Las relaciones entre los distintos artículos que he distinguido en el pasaje pueden esquematizarse de la siguiente manera:

(1) RELACIÓN SIMBÓLICA

(i) Las voces (fonemas) son símbolos de las afecciones del alma, y los grafemas (escritura) son símbolos de las voces $(16 a 3-4)$.

(2) RELACIÓN SÍGNICA

(ii) Las voces son signos de los pensamientos (16a6-7).

(3) RELACIÓN REPRESENTACIONAL

(iii) Los pensamientos son representaciones de las cosas extramentales (16a7-8).

\section{CONVENCIONALIDAD}

Las afecciones del alma, palabras habladas y escritas guardan una relación convencional de parte y contraparte (16a5-6).

\section{CAUSALIDAD}

Las voces significativas (nombres) dependen causalmente de los episodios mentales.

\section{OBJETIVIDAD}

Los conceptos (episodios mentales dependientes del intelecto) son objetivos y universales, en la medida en que representan a (i.e. están por $)^{29}$ las cosas extramentales.

Quisiera examinar ahora un poco más en detalle las dos primeras relaciones distinguidas en la columna de la izquierda, i.e. la simbólica y la sígnica. La discusión

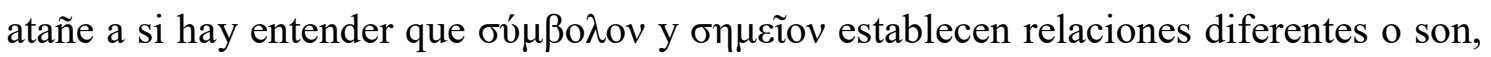

${ }^{28}$ Michael Frede und Günther Patzig, Aristoteles, Metaphysik Z. Text, Übersetzung und

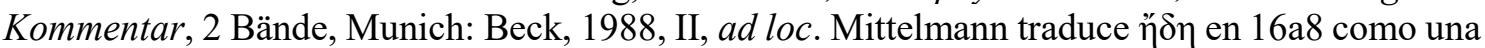
locución adverbial ("desde luego"), lo que, si entiendo bien, conlleva un sentido confirmatorio (sinónimo: "en efecto", "ciertamente"): las cosas extramentales son, desde luego, las mismas para todos (Jorge Mittelmann, Aristóteles, Categorías. Sobre la interpretación. Introducción, traducción y notas, [Categorías] Buenos Aires: Losada, 2008). Miguel Candel Sanmartín, Aristóteles, Tratados de Lógica (Órganon), Vol. II. Madrid: Gredos, 1995, y Ackrill, Categories and The Interpretatione, traducen en un sentido similar como "también"; mientras que Weidemann, Peri Hermeneias; y Polansky-Kuczewski, "Speech and Thought" -entre los pocos que llaman la atención sobre el posible valor de $\eta \delta \eta$ para el argumento- le otorgan el matiz temporal ("auch schon" y "already", en sus traducciones respectivas) que predomina en el registro de Liddell, H. G. and Scott, R. A Greek-Englisch Lexicon [...]. Oxford: Oxford University Press, 1992, s.v.

${ }^{29}$ Este sentido que el representante tiene en Aristóteles es destacado por De Rijk, Semantics, pp. 193, 20-23. 
en cambio, sinónimos. Kretzmann hizo una sugerencia heterodoxa al respecto. Él propuso traducir $\sigma \eta \mu \varepsilon i ̃$ en $16 \mathrm{a} 6$-donde se trata de la relación entre las voces y las afecciones del alma- por symptoms, síntomas o indicadores de otras cosas. Las condiciones que él especifica pueden resumirse de la siguiente manera:

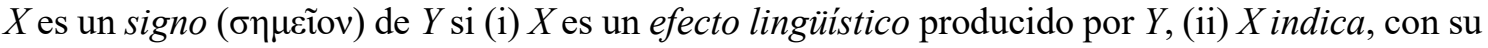
sola presencia, que hay una causa $Y$; (iii) $Y$ qua causa de $X$ puede ser concurrente, o no, con $X$ (aunque en ningún caso se trata de una relación simétrica), (iv) $Y$ se relaciona causalmente con $X$ de manera regular y no convencional, i.e. natural.

Por ejemplo, la fiebre es un signo en el sentido de que constituye un síntoma de una infección que es su causa (simultánea o precedente en el tiempo). Si hay que afirmar una relación natural (no meramente arbitraria ni irregular) entre la fiebre (manifestación corporal al nivel del signo) y la infección de un órgano (la causa de aquella manifestación), debe resultar claro que no se trata, sin embargo, de una relación de semejanza directa. De lo que se trata, antes bien, es de la posibilidad de establecer con cierta firmeza y convicción una inferencia sobre la causa a partir del efecto o la manifestación (de la cual la expresión verbal es una variante). El signo tendría el carácter de este efecto (síntoma). ${ }^{30}$ En la descripción del signo ofrecida arriba, la condición (iii) permite mantener la prioridad explicativa de eventos simultáneos. Si son aplicables aquí las distinciones acerca de prioridad que Aristóteles establece en Categorías 12, en la relación sígnica se trataría, entonces, de un caso en que no se registra implicación recíproca (segundo sentido de anterior, Cat. 14a30). Pero lo específico de esta relación requiere una precisión complementaria. En efecto, ya que $Y$ qua causa puede darse simultáneamente con $X$, la anterioridad causal de $Y$ debe explicarse de acuerdo con el quinto sentido de anterior (14b10-22): dos ítems que se convierten según la consecuencia en cuanto al ser admiten distinguirse entre sí si uno de ellos es anterior por naturaleza, en la medida en que es causa de lo que es el otro, y no a la inversa.

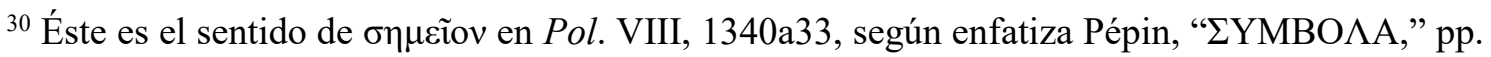
26 ss. ("ces manifestations visibles indicatrices des dispositions morales sont dites en être les 'signes' "). Pépin consigna una serie de pasajes de $H A$ (I 9, 491b15, 24; I 10, 492a4; I 11, 492b2,

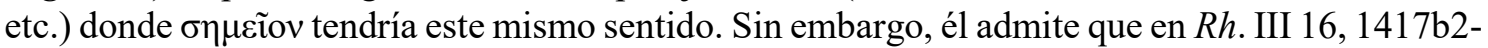
4 , se usa $\sigma u ́ \mu \beta o \lambda$ ov para expresar lo mismo. Un aspecto que para mi propia lectura es interesante en la interpretación de Pépin reside en que él insiste en que, en esos pasajes (especialmente Pol. VIII 5, 1340a32-33), signo se usa en situaciones en las cuales no puede darse una imitación (en el pasaje de Politica, de los caracteres morales) más que sólo indirecta a través de los gestos y movimientos corporales que los ponen de manifiesto naturalmente, en el caso de las artes visuales), es decir, un $\sigma \eta \mu \varepsilon i ̃ o v$ no es un ó $\mu$ oí $\omega \mu \alpha$. 


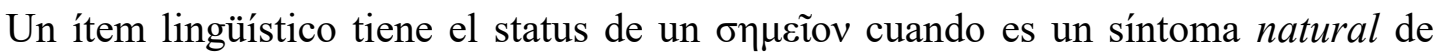
impresiones mentales -adoptando provisoriamente la manera en que Kretzmann entiende las afecciones del alma aristotélicas-. En cambio, un ítem lingüístico sería un oú $\mu \beta 0 \lambda o v$, de acuerdo con el sentido tradicional de este término, en cuanto que se utilizaría como una pieza artificial convencionalmente establecida como contraseña de intercambio y mutuo reconocimiento con una contraparte, la cual representa la otra mitad de la pieza escindida. Kretzmann precisa que $\sigma u ́ \mu \beta o \lambda \alpha$ en $16 \mathrm{a} 4$ no tiene el sentido de una representación simbólica -como el búho simboliza a Atenea-. ${ }^{31}$ Así, se puede entender mejor que la simbolización de una voz (spoken sound) a través de marcas escritas (grafemas) sea independiente de cualquier rol semántico asignado a esos sonidos, y además que la escritura tiene un peculiar carácter convencional. A partir de aquí puede sugerirse que el rol semántico de las voces (que se expresa cuando las voces se califican como signos) no puede depender de una representación natural rancia de las cosas, del tipo de una imitación a través de la voz. Es decir, los significados y la faz semántica de los nombres no dependen de ninguna expresión simbólica particular ya que los símbolos deben ser considerados como marcas convencionalmente aceptadas dentro de un cierto sistema de notación. En síntesis, Kretzmann presenta una lectura heterodoxa al proponer una distinción conceptual entre $\sigma 0 ́ \mu \beta o \lambda o v$ y $\sigma \eta \mu \varepsilon i ̃ o v$, allí donde la mayoría de los autores habían supuesto que ambas expresiones eran sinónimas. ${ }^{32}$

${ }^{31}$ Kretzmann, "Spoken Sound," p. 5 n. 7.

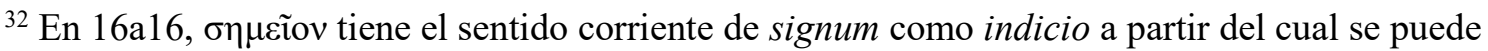
colegir la existencia de otra cosa (cfr. Hermann Bonitz, Index Aristotelicus, Graz: Akademischer Druck- und Verlagsanstalt, $1955^{2}$, pp. $677 \mathrm{a} 43$ ss.). Las traducciones por "símbolo" y "signo", respectivamente, siguen las que realizara Guillermo de Moerbeke (symbola y signa) en su versión latina. Boecio virtió $\sigma u ́ \mu \beta 0 \lambda \alpha$ (16a4) y $\sigma \eta \mu \varepsilon i \alpha ~(16 a 6)$ indiferentemente por notae. Entre los pocos contemporáneos que distinguen ambos términos está, además de Kretzmann, decididamente

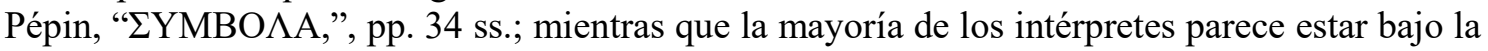
influencia ejercida por la autoridad de Boecio al aceptar la sinonimia de ambos términos. Véase, entre otros, Pierre Aubenque, Le problème de l'être chez Aristote. Essai sur le problématique aristotélicienne, Paris: Presses Universitaires de France, 1994², pp. 106 s.; Montanari, Peri Hermeneias, vol. II, pp. 41 s, 54-57; Polanski y Kuczewski, "Speech and Thought"; Weidemann, Peri Hermeneias, p. 146. Según Pépin, tampoco entre los comentadores árabes parece haberse establecido distinción entre ambos términos, y, como ya en Amonio, parece haber predominado el sentido convencional de $\sigma u ́ \mu \beta o \lambda o v$. En cambio, Theodore Waitz, Aristotelis, Organon Graece, [...] Leipzig: Teubner, 1844, pp. 324-25, como también señala Pépin, distinguió la convencionalidad del $\sigma u ́ \mu \beta 0 \lambda o v$ respecto de la objetividad y universalidad peculiar del $\sigma \eta \mu \varepsilon i o v$. Sobre la interpretación boeciana de De Interpretatione, véase ahora Ana María Mora-Márquez, "Peri Hermeneias 16a3-8. Histoire d'une rupture de la tradition interprétative dans le bas Moyen Âge," Revue Philosophique de la France et de l'Étranger 201/136 (2011): 67-84. 
Aceptaré aquí esta sugerencia de Kretzmann ya que creo que es útil para diferenciar adecuadamente, por un lado, la función identificatoria que tiene la voz en $\{\mathrm{A}\}$, cuando se trata sólo de aclarar su status en relación con los otros dos ítems (i.e. grafemas y pensamientos), $\mathrm{y}$, por otro lado, la función semántica que la voz adquiere en $\{\mathrm{B}\}$ gracias a su vinculación con el pensamiento. La tesis de Aristóteles en $\{A\}$ es simplemente que la voz constituye una pieza de un sistema lingüístico. Este sistema mantiene una doble relación: con el pensamiento -que no es una parte de dicho sistema- y con la notación escrita del sistema en cuestión. La clave en $\{\mathrm{A}\}$ es que los tres dominios constituyen sistemas expresivos interrelacionados de manera correlativa, pero no bidireccional o simétrica, ya que si bien es cierto que existe una correspondencia entre las dos notaciones expresivas, i.e. el grafema y el fonema, no obstante ello, no puede haber una pieza fonética sin su contraparte conceptual, pero sí a la inversa, i.e. sí puede haber para Aristóteles un concepto sin representación lingüística, o al menos el concepto, como tal, no depende de que dispongamos de una notación adecuada para expresarlo al nivel lingüístico. ${ }^{33}$ Por otro lado, si en 16a3-8 predomina la relación semántica (i.e. $\left.\{\mathrm{B}\}\right)$, habrá

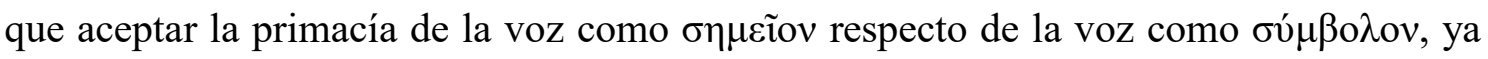
que es mediante el signo que Aristóteles da cuenta de la especificidad de la voz humana, i.e. la producción de un sistema fonético convencional con capacidad de expresar significados que tienen como correlato interno estados mentales representacionales y como correlato externo las formas de las cosas.

En síntesis, la dependencia causal y el carácter representacional secundario o derivado de su relación con el pensamiento (16a6) es el núcleo de la reconstrucción de la noción de signo ( $\sigma \eta \mu \varepsilon i ̃ o v)$, que presenté más arriba, ${ }^{34}$ mientras que el carácter artificial $y$ convencional es el núcleo de la noción de símbolo ( $\sigma u ́ \mu \beta \mathrm{o} \lambda \mathrm{ov})$. En virtud de su carácter de signo, una voz es significativa ( $\sigma \eta \mu \alpha v \tau \imath \kappa o ́ v)$ y expresa un pensamiento a través de

\footnotetext{
${ }^{33}$ He asumido aquí, con la mayoría de los intérpretes, que $\varphi \omega v \eta ́$ significa lo que llamamos fonema, es decir, unidad fonológica que no puede descomponerse, antes bien que palabra; no obstante, no resulta claro ni tal vez necesario que $\varphi \omega v \eta ́$ refiera a unidades últimas o elementos fonéticos ( $\sigma \tau о \chi \varepsilon i \alpha)$. Sobre esto, véase Walther Belardi, Il linguaggio nella filosofia di Aristotele, Roma, 1975, pp. 91 ss.; Montanari, Peri Hermeneias, vol. II, pp. 38, 44 s.; Eduardo Sinnott, Untersuchungen zur Kommunikation und Bedeutung bei Aristoteles, Münster: Nodus Verlag, 1989, p.

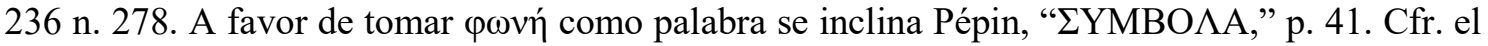
comentario y discusión de Weidemann, Peri Hermeneias, p. 140, quien se inclina también por cierto significado amplio de unidad fonética, que cubre tanto fonema como palabra (con las referencias a Po. 20, 1456b22 s., 1457a 10 s., a14).

${ }^{34}$ Esto subsana una objeción a Kretzmann que hacen Polansky y Kuczewski, "Speech and Thought," pp. $58 \mathrm{~s}$.
} 
cierta notación convencional. Aristóteles recurre a la noción de símbolo para caracterizar ese carácter convencional del nombre, por oposición a un carácter natural que debe ser rechazado como propio de la voz humana: "Pero $<$ decimos $>$ | según convención, porque ninguno de los nombres es por naturaleza, sino $\mid$ cuando $<$ la voz $>$ llega a ser símbolo" (16a26-28). ${ }^{35}$ Así, el signo y el símbolo son complementarios para explicar cómo adquiere significado una voz aristotélica, aunque es el aspecto sígnico el que tiene prioridad, en la medida en que una expresión lingüística es significativa precisamente en virtud de que se constituye en un instrumento para significar una cosa.

\section{1. $\dot{o \mu o i \omega \mu \alpha}$}

La interpretación tradicional del pasaje consta, en realidad, de dos componentes

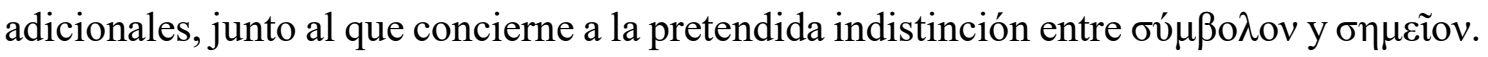
El segundo componente es el que reserva a ó $\mu$ oí $\omega \mu \alpha$ establecer la referencia directa a la realidad extramental. De allí que los partidarios de esa interpretación suelen adoptar la corrección textual de $\pi \rho \omega ́ \tau \omega \varsigma$ por $\pi \rho \omega ́ \tau \omega \nu$ en $16 a 6$ para sustentar la idea -anticipada por Amonio- de que el lenguaje se refiere indirectamente a la realidad, i.e. sólo por intermedio de su referencia directa al pensamiento (infra 5.). El tercer componente de esa interpretación explica las afecciones del alma como imágenes mentales, y atribuye a Aristóteles una teoría del significado acorde con esa explicación, i.e. una teoría figurativa del significado. ${ }^{36}$

Sin embargo, en contra de esta interpretación casi unánimemente aceptada cabe formular dos restricciones. Por un lado, puede suponerse que Aristóteles afirma simplemente que el lenguaje significativo está, en un cierto sentido, naturalmente -i.e. no arbitrariamente- asociado a un estado mental representacional, sin que por ello él esté comprometido con que al usar referencialmente un nombre debemos referir primero al pensamiento. Pero hay otra restricción mucho más importante que imponer a esta interpretación tradicional, y si bien voy a discutir este tópico fundamental al considerar la psicología envuelta en la semántica aristotélica (aquí infra 7.), es oportuno llamar la

35 El nombre es $\sigma 0 ́ \mu \beta 0 \lambda o v$ de contenidos mentales del tipo de los pensamientos y los razonamientos en Sens. 1, 437a15.; SE 1, 165a8. Sobre esto, cfr. Weidemann, Peri Hermeneias, pp. 139 s. (con las referencias a Amonio y Boecio).

${ }^{36}$ Este tercer componente es aceptado incluso por Modrak, Language and Meaning, pp. $20 \mathrm{~s}$. 
atención ahora sobre el débil punto de apoyo de esta tesis central de la interpretación tradicional que pretendo poner en discusión. Pues la atribución de un rol principal a las imágenes en la explicación del significado se sostiene fundamentalmente en la suposición de que ó $\mu$ oเó $\mu \alpha \tau \alpha$ en $16 a 7$ significa semejanza. Ahora bien, si bien es cierto que ése es un sentido de ó $\mu$ oí $\omega \mu \alpha$, está lejos de estar ya resuelto que ése sea el significado relevante en este pasaje, ni que sea además el dominante en contextos similares. Como señalé en mi traducción, ó $\mu$ oí $\omega \mu \alpha$, que puede traducirse como representación, debería entenderse aquí mucho más generalmente en el sentido de sustituir o reemplazar, es decir, como un predicado de dos lugares de argumento: $X$ representa a (está por o en lugar de) $Y$. Parece bastante obvio que no es sólo por medio de una imagen que una cosa puede estar en lugar de otra.

Nuevamente es relevante considerar De Memoria et Reminiscentia. Allí (De Mem. 1, 450b18-451a2) Aristóteles explica el uso de las imágenes en el recuerdo; por el hecho de

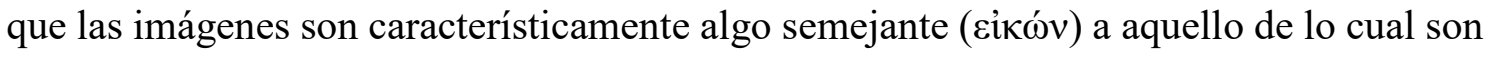
precisamente imágenes, nos permiten recordar objetos particulares. Aristóteles explica que así funcionan las imágenes mentales $(\varphi \alpha ́ v \tau \alpha \sigma \mu \alpha)$. Pero si bien ese modo de representar con ayuda de la semejanza es válido en el caso de la memoria, no estamos autorizados a suponer que Aristóteles supone que todas nuestras representaciones mentales funcionan de esa manera. Otro conocido pasaje puede servir para alimentar la

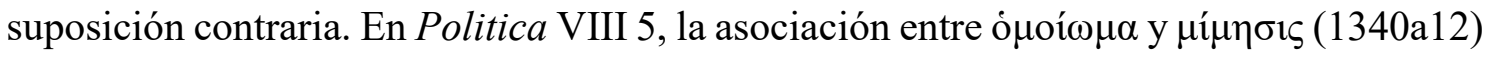
se refiere a la música, i.e. ritmos y melodías que representan y (re)producen estados de ánimo en el oyente. Pero, obviamente, la música no representa algo mediante imágenes. Antes de entrar más de lleno en una discusión de este aspecto, quisiera anticipar que la psicología aristotélica sugiere que sería absurdo que el pensamiento (de cuya representación se trata en Int. 16a7) produjera sustitutos de las cosas por medio de imágenes. En el ya citado pasaje de Sophistici Elenchi 1, 165a7-8, las palabras son símbolos en cuanto que están puestas por las cosas (en la situación de discusión

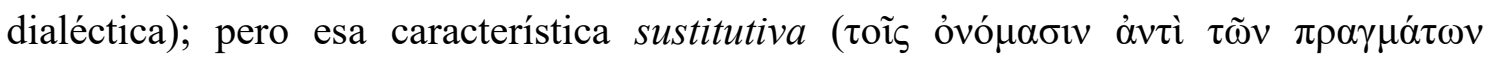

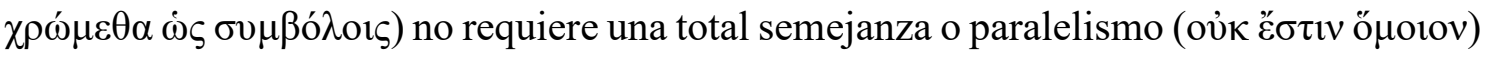
entre ambos órdenes, ya que el número de palabras es limitado (165a10-12). Es claro que el significado de las palabras, en este caso, no depende de un paralelismo con la realidad

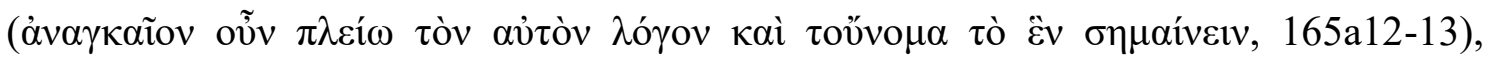
paralelismo que podría buscar asegurarse por recurso a las imágenes, sino que el significado es algo que está ya puesto en operación cuando usamos las palabras como 
sustitutos de las cosas designadas. Esto pone de manifiesto que una clave para interpretar este pasaje de De interpretatione consiste en entender de qué manera los pensamientos o conceptos están en lugar de las cosas.

\subsection{Naturaleza y convención}

Una palabra del lenguaje humano que opera como signo de un pensamiento guarda una relación convencional pero no accidental con el objeto extramental designado. Para que exista tal clase de relación no accidental -que es requerida por el desempeño representacional del pensamiento y por la incidencia causal de la realidad extramental sobre la mente representacional- no es preciso asumir un naturalismo lingüístico à la Crátilo, que supondría que las voces operan como sonidos naturales (e.g. expresiones sonoras y gestuales de animales no humanos que no manejan estrictamente nombres, y fenómenos naturales, como ciertas nubes que son indicios de lluvia, o cierto humo que es signo de la existencia de un incendio). En efecto, en 16a26-28, Aristóteles advierte que la voz significativa que constituye un nombre (ővo $\mu \alpha$ ) en sentido técnico no posee el status de un signo natural, como el que corresponde a los sonidos vocálicos emitidos por los animales irracionales. Por el contrario, la voz se convierte en un nombre genuino cuando adquiere el carácter artificial y convencional característico de un símbolo, sin que tal asociación artificial vaya en desmedro de que los usuarios del lenguaje estén inclinados, precisamente por la fuerza del uso, a asociar una palabra con una cosa determinada. ${ }^{37}$ En efecto, el vínculo no accidental de la voz con el pensamiento no contradice que una voz, para convertirse en vehículo semántico, deba ser reconocida y establecida como parte de esa clase de artificio que es un sistema gramatical con su intrínseco carácter convencional. Para Aristóteles, lo relevante no es que la voz sea un sonido natural, sino que exista una convención que le reconoce a ese sonido un valor semántico determinado. En la sección $\{B\}$ del pasaje tampoco está en primer plano el acoplamiento de los sistemas de notación y representación -el gráfico, el fonético y el mental, cada uno de ellos parcialmente cerrado en sí mismo-, sino la función vehicular que reviste un sonido cuando es usado semánticamente como índice o síntoma de un pensamiento. Por eso, sólo en $\{\mathrm{B}\}$ aparece en primer plano el carácter propiamente

${ }^{37}$ En ciertos contextos, esa inclinación a asociar indisolublemente la palabra, tomada como símbolo, a la cosa mencionada puede ser fuente de confusiones, como lo señala $S E 1,165 \mathrm{a} 6$ ss. 
semántico del lenguaje humano, por el que una voz es significativa al convertirse en vehículo de un contenido intencional. Obviamente, una posición de este tipo requiere establecer alguna distinción entre el nivel fonético y la estructura semántica profunda de una lengua. Si el convencionalismo y los cambios históricos de una lengua se dan en el primero de esos dos niveles -el del símbolo-, mientras que la fuerza semántica reside propiamente en el segundo -el del signo-, es probable que Aristóteles esté haciéndose eco de la discusión que sobre este aspecto Platón desarrolla en el Cratylus. Allí, Platón parece querer restringir el relativismo epistemológico, que se seguiría de cierta versión del convencionalismo lingüístico, limitando la convención al nivel fonético, y manteniendo que diferentes fonemas deben poder representar la misma cosa. La tesis resultante es que la realidad y el pensamiento que la capta son lo mismo para todos (383a, 389de, 414cd, 435ad).

Mi sugerencia anterior sobre el nivel profundo del lenguaje es coherente con una posible lectura de De Sensu et Sensibilibus 437a9-15, ${ }^{38}$ según la cual el lógos (que es causa del aprendizaje) es sólo accidentalmente audible, en la medida en que se expresa en palabras que son símbolos (de pensamientos o conceptos). ${ }^{39}$ No somos capaces de aprender por el hecho de que escuchamos un lógos audible (expresión verbal), sino más bien por el hecho de que somos capaces de entender el lógos (lenguaje) que se expresa mediante las palabras en su rol simbólico. Así, la comunicación lingüística que permite la enseñanza y el aprendizaje necesita de la expresión verbal, pero el lenguaje significativo (que es el medio de la comunicación) no es idéntico a la expresión verbal. De tal manera, encontramos dos relaciones: (1) una accidental pero necesaria entre lenguaje (expresión verbal) y lógos -el hecho de que esta relación sea necesaria explica que, al estar provisto de razón, un ser humano adopta de por sí un comportamiento lingüístico; mientras que el hecho de se trate de una relación accidental le da prioridad explicativa a la formación de conceptos ante la expresión lingüística de los mismos-; $;{ }^{40} \mathrm{y}$

${ }^{38}$ Cfr. Wedin, Mind and Imagination, pp. 147 ss. Una lectura diferente presenta Jean-Louis Labarrière, "Imagination humaine et imagination animale chez Aristote", Phronesis 29 (1984): $17-49$.

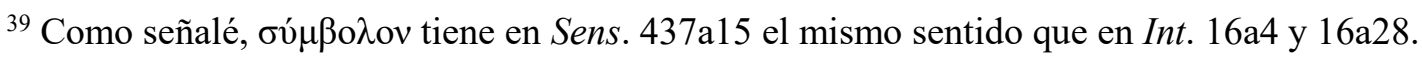

${ }^{40} \mathrm{O}$ al menos tal es la manera en que propondré aquí entender la dependencia entre lenguaje y pensamiento en Aristóteles. 
(2) una relación absolutamente necesaria entre lógos (no en el sentido simbólico de un “linguistic token") y conceptos mentales. ${ }^{41}$

Creo que esta posible herencia platónica que recibe Aristóteles en De Interpretatione puede explicar el descrédito del naturalismo lingüístico que se encuentra brevemente en el pasaje ya citado de 16a26-28. En efecto, teniendo en cuenta ese trasfondo teórico puede interpretarse mejor el carácter simbólico-convencional de las voces que se halla en la sección $\{\mathrm{A}\}$ del pasaje. En relación con las unidades semánticas elementales -i.e. los nombres (ỏvó $\mu \alpha \tau \alpha)-$, Aristóteles sostiene que ellas no adquieren significado en virtud de que sus partes aisladas (sílabas y letras) lo posean, sino que lo poseen sólo gracias al uso sancionado por la convención que convierte a un cierto sonido vocálico o a un cierto grafema en vehículo de significado. Aristóteles parece querer defender a ultranza esa posición, a pesar de que, en nombres compuestos, podría parecer lo contrario, ya que algunos nombres simples, que forman parte de otros compuestos, poseen indudablemente un significado independiente. Sin embargo, él afirma que en "barco-pirata", "pirata" debe poseer su propio significado sólo dentro del nombre compuesto, mientras que por sí no funciona semánticamente de la misma manera que integrado al compuesto (16a24-26). $\mathrm{Su}$ idea es que un nombre simple integrado a otro compuesto debe funcionar semánticamente de una manera similar a una sílaba dentro de un nombre. Es decir, el valor semántico tanto de un nombre simple -que es parte de otro compuesto- como también de una sílaba -que forma una palabra pero carece por sí de significado- se explican por el significado del compuesto y de la palabra, respectivamente (16a22-26).

En De Interpretatione 17a1-2, Aristóteles rechaza que un enunciado signifique como

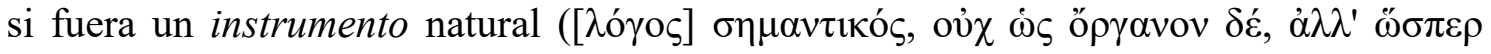

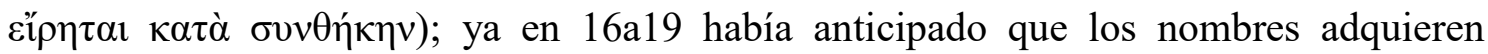
significado en el seno de usos y convenciones. ${ }^{42}$ Esto hace referencia posiblemente a la errónea concepción naturalista del significado, que llevaría a suponer que las letras de un nombre deberían tener significado; por ejemplo la desinencia vৎ en el nombre $\mu \tilde{\varsigma} \varsigma$ (ratón). Aristóteles se opone a ello en 16b30-33: una sílaba o cualquier otra parte de un nombre

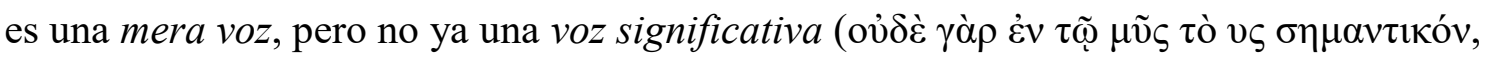

\footnotetext{
${ }^{41}$ Como argumento aquí, para esta última relación Aristóteles explica que el lenguaje opera como signo.

${ }^{42}$ Para la posible referencia al Cratylus platónico contenida en ello, cfr. Weidemann, Peri Hermeneias, pp. $190 \mathrm{~s}$.
} 


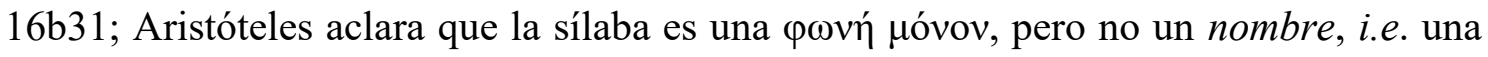

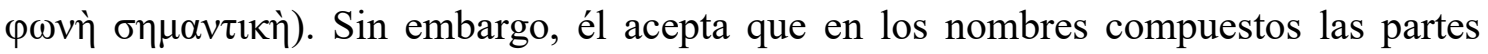
separadas hacen alguna contribución semántica, efectivamente, quieren decir algo (̇̉v $\delta \grave{\varepsilon}$

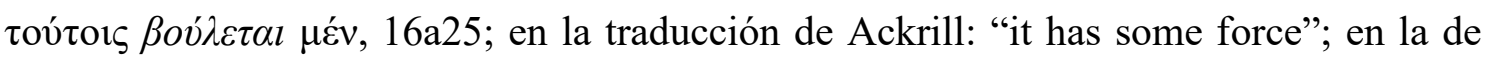
Weidemann: "bei diesen zwar etwas bedeuten soll”). De allí que en 16b32-33 a la estricta carencia de significado de las sílabas de un nombre simple Aristóteles contrapone lo que podría llamarse el significado parcial o dependiente del todo que les corresponde a los nombres simples integrados en nombres compuestos: el significado del nombre-parte no es independiente del significado del nombre-todo, sino que es una función de éste ( $\dot{\varepsilon} v \delta \grave{\varepsilon}$

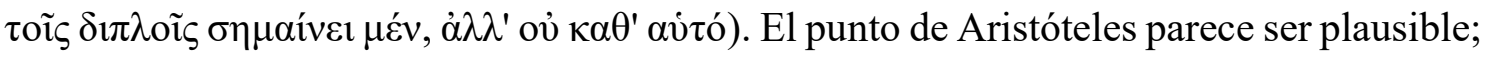
por ejemplo: el significado que tiene "mental" en "extramental" no corresponde exactamente al que tiene ese nombre simple tomado por separado (para el ejemplo de Aristóteles, cfr. 16a25-26), ya que en el nombre compuesto la misma composición debe resultar en una contribución semántica no reductible a la que hacen las meras partes.

No obstante, el carácter irreductible que posee el significado del nombre-todo con relación a los nombres-parte constituye una importante suposición que Aristóteles no aclara suficientemente. Él parece asumir que puesto que los nombres-parte (no ficticios) tienen un significado propio, por el hecho mismo de que son nombres simples, ellos efectúan una contribución al significado compuesto; pero si realmente el significado de los nombres simples integrados a otro compuesto es dependiente de este último, otra suposición de Aristóteles debe ser que el significado del nombre compuesto no se explica como un agregado o como una mera suma de los simples.

En De Interpretatione 18a18-26, Aristóteles considera un caso en que un nombre compuesto putativo ("vestido") no designa una unidad semántica genuina entre nombres simples ("hombre-caballo"); en ese caso, el nombre compuesto no tiene un significado propio e irreductible, sino que significa muchas cosas, lo que parece querer decir que un nombre compuesto semánticamente no irreductible no tiene un significado propio ya que "hombre-caballo" no significa algo provisto de unidad semántica. Para la cuestión del significado de los nombres-parte es irrelevante si los nombres compuestos son reales ("barco-pirata") o ficticios ("capricervo"), aunque, obviamente, la fijación del significado de los nombres ficticios no se produce por la captación mental de un objeto compuesto 
existente, sino por medio de una composición de nombres simples producida en la mente, posiblemente, por medio de la imaginación. ${ }^{43}$

\section{La dependencia de las palabras y la cuestión de fondo en la alternativa textual entre} $\pi \rho \omega ́ \tau \omega v$ y $\pi \rho \omega ́ \tau \omega \varsigma$ (Int. 16a6)

La principal cuestión textual que suscita el pasaje inicial de De Interpretatione es la alternativa entre $\pi \rho \omega ́ \tau \omega v$ у $\pi \rho \omega ́ \tau \omega \varsigma$ en 16a6. ${ }^{44}$ Traduje esta línea así: "Mientras que aquellas cosas de las cuales éstas son primeramente signos, las afecciones del alma, son las mismas para todos", es decir, tomando el genitivo $\pi \rho \omega ́ \tau \omega \nu$ en el texto de MinioPaluello, que tendría un mejor apoyo en los manuscritos. Ahora bien, como lo destaca Weidemann, remitiéndose a Montanari y a Magee, hay un sentido adverbial del genitivo que es gramaticalmente posible, y es el que le dieron, de hecho, los comentadores antiguos. ${ }^{45}$ Montanari sugiere que precisamente de este sentido adverbial del genitivo habría surgido la variante con el adverbio como una intervención en el texto transmitido. Bajo esta suposición, con cualquiera de las dos variantes el sentido filosófico del pasaje sería que el lenguaje es primeramente signo de las afecciones del alma; y está tácito que serían en segundo orden signos de las cosas externas. Hasta aquí, no hay nada que objetar a la lectura tradicional. Sin embargo, hay una cuestión filosófica de fondo en torno de la cual creo que hay que distanciarse de la lectura tradicional. Pues estas líneas no son suficientes para comprometer a Aristóteles con la cuestionable idea de una referencia indirecta de las palabras, tal como parece haber defendido Amonio y, con él, la mayoría de los intérpretes de este pasaje. ${ }^{46}$ Según esa idea, cuando referimos a las cosas por medio

${ }^{43}$ Para una discusión detallada, cfr. Weidemann, Peri Hermeneias, pp. 160-166. Mi propia interpretación sobre el significado no independiente de los nombres-parte coincide básicamente con la de Charles, Meaning and Essence, p. 88. En la propuesta de Charles, los nombres compuestos (estrictamente, los ficticios) tienen un significado "inmediato" (el pensamiento) disociado del "mediato" (el objeto o la especie existente); en los simples, no existiría tal disociación.

${ }^{44}$ Como alternativa textual se cuenta también $\pi \rho \tilde{\omega} \tau o v$, que es aparentemente una corrección del genitivo. Sobre la fijación del texto, cfr. Montanari, Peri Hermeneias, vol. I, p. 109; vol. II, p. 13; Weidemann, Peri Hermeneias, pp. 143 ss.

${ }^{45}$ De allí la traducción de Weidemann, Peri Hermeneias, p. 3: "Die seelischen Widerfahrnisse aber, für welche dieses (Gesprochene und Geschriebene) an erster Stelle ein Zeichen ist, sind bei allen Menschen dieselben [...]".

${ }^{46}$ Amonio, in Int. 17, 24-26, 24, 5-9. Véase la discusión en Montanari, Peri Hermeneias, vol. I, pp. 126 ss.; vol. II, pp. 47 ss.; Whitaker, De Interpretatione, pp. 20 ss. Polansky y Kuczewski, "Speech and Thought,", pp. 61 ss., se inclinan por la interpretación de Amonio; véase también 
de las palabras en realidad hacemos una referencia directa a los pensamientos. Esto supondría, entre otras cosas, que la comunicación lingüística entre hablante y oyente (ò

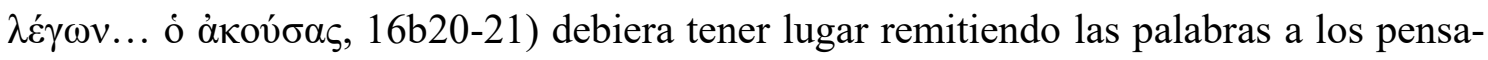
mientos y no a las cosas designadas por las palabras y representadas a través de los pensamientos. Para una posición realista, como la que aquí le he atribuido a Aristóteles -es decir, una posición que, si bien admite que la fijación del significado de las palabras se hace a través del efecto causal primero que tiene el mundo externo sobre los pensamientos, no se compromete con que la cosa significada por las palabras sean esos pensamientos, sino los correlatos externos, o sea, el mundo tal como es aprehendido por los pensamientos-, una explicación de este tipo entrañaría un problema realmente serio, en la medida en que lo que ocurre en la comunicación lingüística no es tomar contacto con los pensamientos del interlocutor, sino distinguir directamente cómo son las cosas. ${ }^{47}$ Para Aristóteles, la fijación de la referencia y la comunicación, dicho en una jerga de moda hace un tiempo, involucran al mundo. De lo contrario, y si además asumiéramos con la opinión mayoritaria de los intérpretes, que el pensamiento consiste en formarse una imagen o semejanza mental, de acuerdo al sentido literal que se le da a ó $\mu$ otó $\mu \alpha \tau \alpha$ en 16a7, entonces estaríamos frente a una teoría que explicaría el significado de las palabras por recurso a que el oyente accediera, de alguna manera, a las imágenes grabadas en la mente del hablante. ${ }^{48}$

El texto de $16 a 6$ puede interpretarse tomando un compromiso diferente en cuanto a la articulación de primero-segundo, más precisamente, en términos de dependencia. En efecto, simplemente puede querer decir que la referencia lingüística a las cosas externas se produce no sin que las palabras expresen los pensamientos con los cuales captamos aquello que significamos lingüísticamente. Esta última manera de entender el texto

Montanari, Peri Hermeneias, vol. II, pp. 46 s.; Pépin, "IYMBO $\Lambda$ A," pp. 37 s. Como vimos, Weidemann, "Repräsentationalist," es una notable excepción a esta dominante lectura. Pépin detecta un posible problema en la interpretación tradicional, ya que, por un lado, en ella se acepta la sinonimia entre símbolo y signo (16a3-4), mientras que se pasa por alto la importancia que puede tener $\pi \rho \omega ́ \tau \omega \varsigma$ para la calificación de las voces como signos (16a6). Pépin propone una original lectura que, sin embargo, no me parece del todo convincente: él cree que hay que suponer un $\delta \varepsilon v ́ \tau \varepsilon \rho \omega \varsigma$ como calificativo de la relación simbólica entre las voces y los estados del alma, correspondiente al $\pi \rho \omega ́ \tau \omega \varsigma$ que califica la relación sígnica entre las voces y los estados del alma.

${ }^{47}$ Las dos operaciones lingüísticas involucradas -comunicación y distinción de la esencia-fueron identificadas por Platón en Cra. 388b10-c1.

${ }^{48}$ Charles, Meaning and Essence, pp. 83 s. mantiene que "[...] signification relation reaches from our words beyond our thoughts to the world". 
implica aceptar una relación de dependencia unidireccional -la fuerza significativa de las palabras depende de la capacidad intelectiva, y no viceversa-, pero sin asumir que los pensamientos serían, estrictamente, lo primero referido por las palabras. Si esto es así, se confirma nuevamente que el signo guarda prioridad ante el símbolo desde el punto de vista semántico, puesto que, a pesar de que en 16a5-6 Aristóteles ha sostenido que las palabras tienen un carácter convencional (no son las mismas para todos), en 16a6 recurre a la calificación de las palabras como signos de los pensamientos para aclarar en qué medida ellas no sólo son la contraparte (símbolo) de un pensamiento, sino que, por su relación sígnica con el pensamiento, expresan o significan las cosas. ${ }^{49}$

\section{El nombrar y el significar}

He sostenido que en De Interpretatione 16a3-8 aparecen tres órdenes de relaciones diferentes. El (2), caracterizado por la relación sígnica, atañe al vínculo entre las voces significativas y las afecciones del alma; el (3) concierne a la relación representacional $\left(\dot{o} \mu \operatorname{í}_{\omega \mu \alpha}\right)$ que vincula el pensamiento con la realidad extramental independiente. Me propongo ahora considerar el aspecto semántico-representacional envuelto en (2) y (3).

Si bien Aristóteles no explicita sus tesis sobre el significado, ${ }^{50}$ su idea al respecto se pone de manifiesto de manera bastante clara al momento de distinguir entre nombres significativos y otras expresiones lingüísticas y físicas estrictamente no significativas. Me referiré al concepto técnico de nombre que maneja De Interpretatione como nombre aristotélico, y examinaré las distintas maneras de significar que identifica Aristóteles: por un lado, las que producen el sujeto y el predicado, siendo ambos términos simples; por otro lado, la que produce un enunciado declarativo que surge de la combinación de esas dos funciones diferentes de los términos simples mencionados. Otras maneras de significar a través de enunciados no declarativos caen fuera del interés de $D e$ Interpretatione (17a5-7).

\footnotetext{
${ }^{49}$ Esta distinción no aparece reflejada en el triángulo semiótico que presenta Weidemann, Peri Hermeneias, pp. 149, 139, para quien un símbolo es meramente un signo cuyo significado se establece de manera no natural, sino convencional.

${ }^{50}$ Modrak, Language and Meaning, p. 13, advierte que "Aristotle grapples with the topic of meaning head-on in only one place - at the beginning of the De Interpretatione". Ella añade que, en la lectura más caritativa, ese pasaje es "comprimido y elíptico". Por eso, resulta adecuado reconstruir el contexto del pasaje.
} 
Ackrill y Kretzmann sugieren que "voz significativa según convención” (16a19) constituye el género próximo del cual tanto el sujeto como el predicado y también los enunciados constituirían sus especies. ${ }^{51}$ Esta plausible observación indica que para entender correctamente el concepto de significado que Aristóteles maneja hay que tomar en consideración tanto las unidades de significado como también las nociones de voz y de convención, además de las condiciones para que una voz convencional se convierta en vehículo de significado.

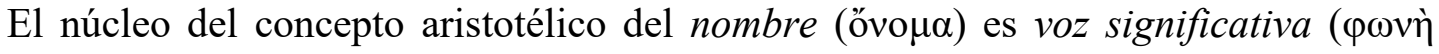
$\sigma \eta \mu \alpha v \tau 1 \kappa \eta ̀)$. Un nombre aristotélico simple funciona como sujeto o como predicado proposicional. De Interpretatione define un nombre aristotélico de la siguiente manera:

Un nombre es una voz significativa por convención | sin indicación de tiempo, de la cual ninguna parte separada es significativa. (16a19-20)

Se trata de una caracterización general independiente de las dos funciones lógicogramaticales diferentes que puede adoptar un nombre aristotélico, i.e. como sujeto y como predicado, dentro de la clase de enunciado que focaliza De interpretatione 5 , i.e. el enunciado declarativo, y, en primer lugar, el simple ( $\dot{\alpha} \pi \lambda \tilde{\eta} \dot{\alpha} \pi$ ó $\left.\alpha \alpha \sigma \_\varsigma\right)(17 \mathrm{a} 23-24) .{ }^{52} \mathrm{De}$ pasajes como Poetica 20, 1457a10-12 puede recabarse, complementariamente, que un ővo $\mu \alpha$ es una voz compuesta de sílabas y letras (en general, 1457a10-18). En 16b2-21, los comentadores reconocen una referencia al Cratylus (437a1-9) en la caracterización aristotélica de los nombres explicados en términos de que, a través de ellos, el alma alcanza un detenimiento. Como lo destaca Weidemann, la comparación con el detenimiento puede aclararse intrínsecamente a través de la captación del universal de Analíticos Segundos II 19, 100a6 s., a15 s.; y esto permite iluminar otro rasgo de los nombres aristotélicos, i.e. el hecho de que significan un universal. ${ }^{53}$ En efecto, en razón de que $\pi \rho \alpha ́ \gamma \mu \alpha \tau \alpha$, i.e. el correlato externo de nombres y conceptos en 16a7, incluye tanto objetos particulares como universales (17a38-b1), no hay razón para restringir los nombres aristotélicos a la categoría gramatical de nombres propios.

${ }^{51}$ Ackrill, Categories and The Interpretatione, p. 115; Kretzmann, "Spoken Sound," p. 3 n. 3; Weidemann, Peri Hermeneias, pp. 155, 158 s. En Po. 20, 1457a16-18, Aristóteles opone de otra manera los nombres a los verbos, incluyendo bajo los primeros tanto a los que cumplen la función de sujeto como de predicado oracional. Sobre todo esto, véase De Rijk, Semantics, pp. 131-2, 193-257.

${ }^{52}$ La razón por la cual un enunciado es simple se da en 17a15-16: muestra una sola cosa o tiene una conexión entre sus partes.

${ }^{53}$ Weidemann, Peri Hermeneias, pp. 136 s. 
La noción de predicado ( $\dot{\rho} \tilde{\mu} \mu \alpha)$ (nominal y verbal) se aclara como la de signo de algo en cuanto que esto se dice de otra cosa (16b7), con lo cual la noción del sujeto está presupuesta en la de predicado:

Y siempre | es signo de las cosas que se dan a la manera en que lo hacen las que se dicen de un sujeto $(16 \mathrm{~b} 9-10)$.

Entre los predicados, Aristóteles distingue aquellos que expresan una acción (sana) y aquellos que meramente expresan un atributo (culto) del sujeto; los primeros añaden al significado del nombre del cual se derivan (salud) una determinación temporal, es decir,

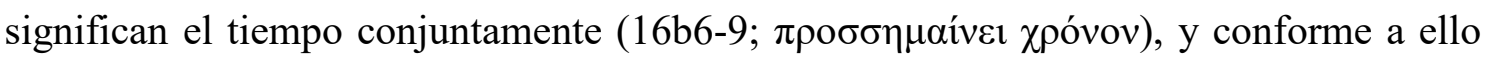
modifican el sujeto. Tanto el término que ocupa el lugar del sujeto proposicional como el que ocupa el lugar del predicado son nombres aristotélicos en virtud de que funcionan como signos de algo y poseen un significado propio o independiente (para el caso del sujeto, cfr. 16a19-21; para el del predicado, cfr. 16b10, b19-20). No es implausible suponer (también con Weidemann) que Aristóteles debe admitir como correspondiente al estado de cosas (correlato externo de la proposición, que también es cubierto por la palabra $\pi \rho \tilde{\alpha} \gamma \mu \alpha)$ un estado mental análogo al que él presupone para el nombre y su correlato externo. En efecto, la caracterización del nombre en 16a19-20 es suficientemente flexible como para alcanzar también a las voces significativas complejas, más precisamente, las que se producen mediante un enunciado.

\subsection{El significado de ser}

Lo anterior permite entender que Aristóteles rechace que es y no es cuenten como genuinos predicados, en la medida en que no constituyen un nombre o signo con un significado propio e independiente:

[...] pero <el predicado verbal $>$ no significa aún si $<$ lo significado por él $>$ es o no $<e s>$; | pues ser o no ser no es un signo de la cosa, ni tampoco si se dijera meramente lo que es (Int. 16b2123).

En este difícil pasaje, que ocupó a los comentadores desde Amonio hasta Weidemann, se presentan los siguientes principales problemas interpretativos: (a) ¿cómo se relaciona la consideración sobre el "es" con la tesis precedente sobre los predicados verbales?; (b) ¿qué papel argumentativo cumple la cláusula que comienza con $\gamma \alpha ́ \rho$ en 16b22?; y en un orden secundario (c) ¿tiene incidencia en el sentido la posible variante

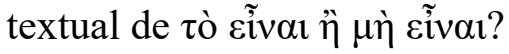


Las dos cuestiones principales están planteadas obviamente en (a) y (b) ${ }^{54}$ Aristóteles

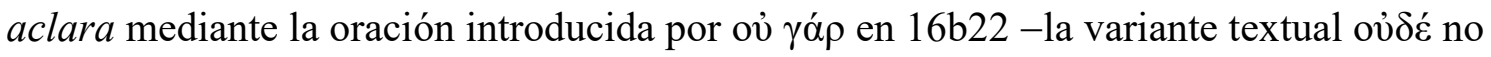
conlleva una variación en el sentido- que el añadido de la cópula es una condición necesaria para que lo significado por un predicado se enuncie como algo que es o no es (con relación a un sujeto). Es decir, el predicado verbal, que significa algo por sí mismo, no constituye ya de por sí un enunciado (16b19-22) pues para formular un enunciado hace falta la función de ligazón de la cópula (cfr. el paralelo en 4, 16b28-30). Esta última, a pesar de cumplir la función sintáctica de un verbo, semánticamente es incompleta y, en tal sentido, se distingue del predicado verbal ( $\dot{\rho} \tilde{\eta} \mu \alpha)$, ya que carece de significado propio

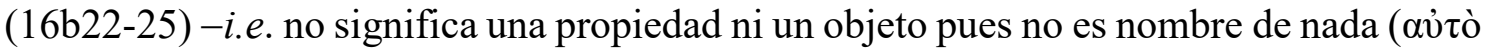

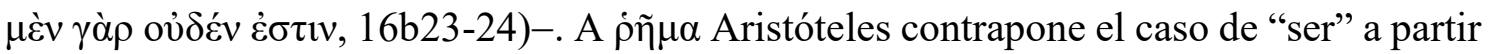
de $16 \mathrm{~b} 22$ tanto en su forma verbal de infinitivo como también en la forma nominal de

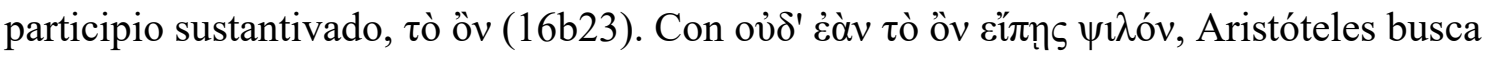
mostrar que tampoco el uso aislado del verbo "ser" como participio sustantivado designa una $\cos a .{ }^{55}$ El punto es que "es" no tiene significado propio ya que no constituye un signo

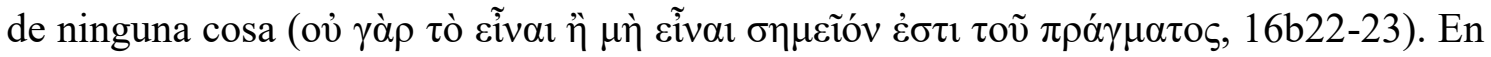

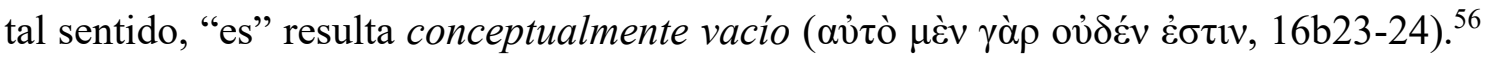
No obstante, el "es" copulativo obtiene su peculiar significado a partir del conjunto que mediante él se compone. Éste debe ser el sentido de "co-significa cierta composición"

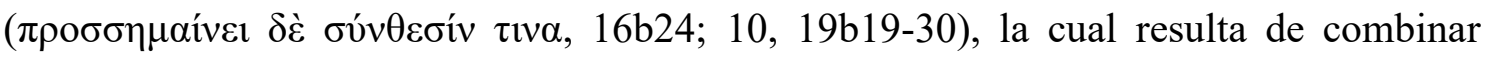
nombres de objetos y propiedades (16b24-25; cfr. 12, 21b25-28) ${ }^{57}$ Esa "composición"

\footnotetext{
${ }^{54}$ El punto (c) no requiere aquí un tratamiento especial. La alternativa en la lectura de 16b21-22 fue planteada por Boecio en su traducción (neque enim esse signum est rei vel non esse), y consiste en tomar esse y non esse o bien como nominativo en función de sujeto de signum rei o bien como genitivo dependiendo de signum. A pesar de que (pace Weidemann) Boecio junto a los comentadores medievales tardíos y el mismo Weidemann se inclinan por la segunda opción, que parece haber correspondido a la lectura de Porfirio (en genitivo $\tau$ oṽ Eiv $\alpha$ l), me inclino por la primera opción (es la que también adoptan Ackrill y Mittelmann en sus respectivas traducciones) ya que me parece la más clara. De cualquier modo, la posible variante textual no incide decisivamente en el sentido.
}

${ }^{55}$ Asumo que $\pi \rho \tilde{\alpha} \gamma \mu \alpha$, en $\sigma \eta \mu \varepsilon \tilde{i o ́} v \dot{\varepsilon} \sigma \tau \iota ~ \tau o \tilde{~} \pi \rho \alpha ́ \gamma \mu \alpha \tau o \varsigma(16 b 22-23)$, está por aquello que significa un predicado, i.e. por una propiedad. Tal clase de cosa sería aquello por lo cual la palabra "es" no puede estar. $\pi \rho \alpha ́ \gamma \mu \alpha \tau \alpha$ no se limita a objetos particulares (17a38-40).

${ }^{56}$ De Rijk, Semantics, p. 217, lo llama empty container: privado, por sí mismo, de valor o contenido semántico.

${ }^{57}$ Aristóteles añade que tal composición (la plena aserción o proposición) no puede ser pensada

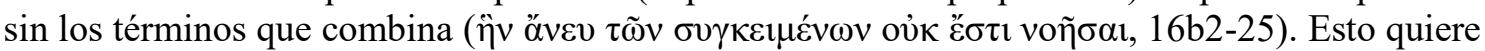


( $\sigma 0 ́ v \theta \varepsilon \sigma ı \varsigma)$ es el tema del siguiente capítulo, y debe entenderse aquí en el sentido de $\tau \grave{\alpha}$

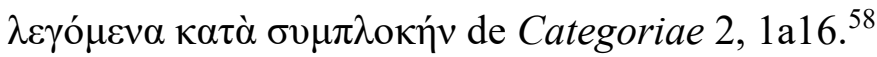

En síntesis, pueden destacarse tres puntos en el argumento del pasaje. (i) En 16b21-

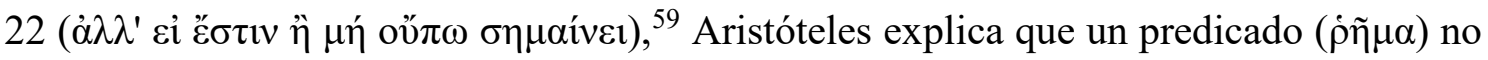

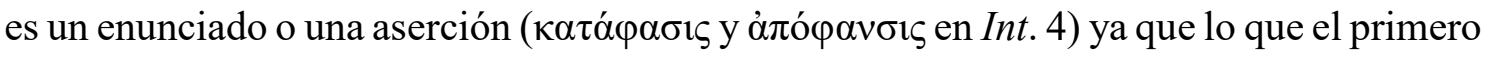
significa no dice si algo es (el caso) o no es (el caso) (con respecto a un sujeto). ${ }^{60}$ (ii) La cláusula de yó $\rho$ en 16b22 introduce una aclaración parentética que se extiende hasta $16 \mathrm{~b} 25$ y se refiere a un verbo, el "es" (tanto en su forma verbal como también en la nominal), en el marco de una consideración general sobre los predicados verbales; además, (iii) aquí se anticipa Aristóteles a una posible objeción cuando afirma que la cópula no funciona estrictamente como un predicado verbal, pues no tiene el significado corriente de un nombre, i.e. el "es" copulativo no significa nada por sí mismo. ${ }^{61}$ Contrariamente a la expectativa que puede despertar la conjunción causal $\gamma \alpha \grave{\alpha} \rho$, Aristóteles no explica propiamente lo que sostiene sobre los predicados verbales; quizá él supone que a esta altura del desarrollo de su argumento ya resulta suficientemente claro que un predicado verbal, por sí mismo, no realiza una aserción. En cambio, Aristóteles explica

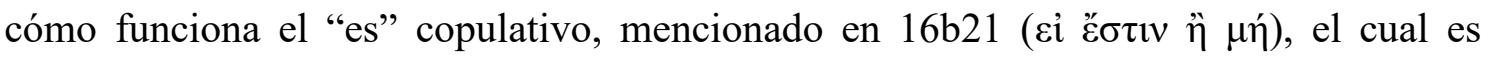
propiamente el responsable de que se forme una aserción. La interpretación del significado del ser que lo toma como una función de ligazón proposicional con significado parasitario se distingue de aquella otra que admite que en la forma de participio (el ente), y bajo la suposición de que el participio sería simplemente otra manera

decir, probablemente, que el significado de una proposición no puede determinarse aparte de sus componentes.

${ }^{58}$ Una lectura alternativa a la que he adoptado sugiere, en cambio, que Aristóteles mantiene que el verbo "es" forma parte de expresiones verbales como "es caminante" (Int. 12, 21 b9 s.), que no constituyen una aserción. Sobre esa base, él argumentaría que, en general, cualquier verbo puede ser expresado explicitando el "es" que contiene tácitamente (pero sin constituir una aserción). Ackrill, Categories and The Interpretatione, pp. 121-124; y Weidemann, Peri Hermeneias, pp. 178-187, ofrecen algunos argumentos para rechazar esta lectura.

59 "Pero aún no indican si [lo significado] es o no es" (trad. Mittelmann). El mismo uso de "si es

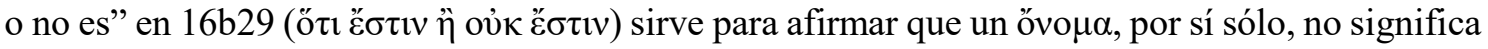
si algo es o no es.

${ }^{60}$ Cfr. Ackril, Categories and The Interpretatione, p. 121.

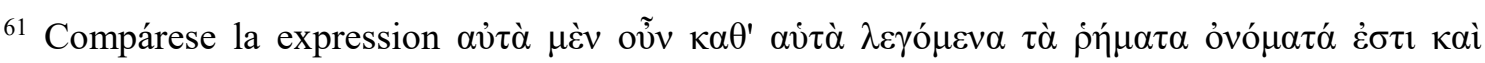

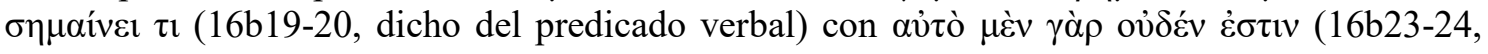
dicho del ser o lo que es). 
de expresar la forma verbal conjugada (e.g. "es"), se incluye la referencia al ser de algo, i.e. a que algo existe. ${ }^{62}$

Ahora bien, en la lectura del argumento de Aristóteles que hasta aquí he presentado tomo distancia de la manera en que Ackrill reconstruye el pasaje, ${ }^{63}$ ya que no acepto que en 16b22-25 Aristóteles responda a una posible objeción que sugeriría que "es" (“existe") realizaría una aserción de existencia y, por lo tanto, constituiría de por sí una aserción.

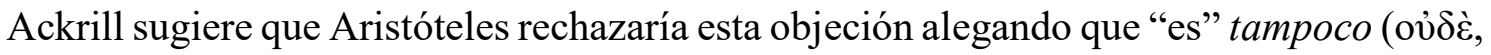
en la variante textual adoptada por Ackrill) puede tomarse como un signo de un hecho o estado de cosas. Es decir, para Ackrill, Aristóteles buscaría mostrar que, tal como cualquier $\dot{\rho} \tilde{\eta} \mu \alpha$, "es" no tiene un importe existencial. Si bien esto es teóricamente correcto, no creo que Aristóteles argumente allí de esa manera ya que la aserción de existencia no es propiamente la clase de enunciado en la cual él está pensando en 16b2122. En efecto, la clase de enunciado que él allí considera es, más bien, el enunciado declarativo o predicación. Por lo tanto, la aclaración sobre el significado del "es" en 16b22-25 debe entenderse en referencia a la predicación, y no a las aserciones de existencia.

\subsection{Significado y proposición}

En De Interpretatione $16 \mathrm{~b} 26$ ss., Aristóteles establece su conocida distinción entre dos maneras de significar: la que corresponde a un nombre y la que corresponde a un enunciado. Mientras que el nombre, en tanto que es la parte significativa elemental de

\footnotetext{
${ }^{62}$ En esta línea, Tomás de Aquino explicitó el ens como equivalente a quod est; en esto es seguido por Montanari, Peri Hermeneias, vol. II, pp. 267 s., 276 s., 280. En contra de esa lectura tradicional, cfr. Ackrill, Categories and The Interpretatione, pp. 123 s. (para quien el argumento de Aristóteles en estas líneas del final de Int. 3 no apunta a que la falta de importe existencial sería peculiar del verbo "ser", puesto que ningún verbo, por sí solo, posee importe existencial ya que no constituye una aserción, i.e. un $\dot{\eta} \tilde{\mu} \alpha$ no enuncia que algo es o no es el caso); y Weidemann, Peri Hermeneias, pp. 185 s. (contra el sentido existencial de "ente"). La discusión más actualizada y erudita del pasaje 16b19-25 es probablemente la de De Rijk, Semantics, pp. 215-48, 87 ss. Mayormente los comentadores modernos, como señala De Rijk, rechazan la relevancia del significado existencial del verbo "ser". Sin embargo, otra cuestión es si se interpreta que Aristóteles formula al final de Int. 3 un argumento sobre ello o no (De Rijk defiende la heterodoxa visión según la cual no hay allí tal argumento, y por mi parte me inclino por esa interpretación). Por otro lado, De Rijk insiste en el origen neoplatónico, debido a Amonio y propagado por Boecio, de la interpretación alternativa del significado de "es" como sincategoremático y de su función copulativa en la formación de los enunciados.
}

${ }^{63}$ Cfr. Ackrill, Categories and The Interpretatione, pp. 123 s. 
una sentencia, significa algo simple sin indicar si eso es el caso o no (óv $\theta \rho \omega \pi$ o $\sigma \eta \mu \alpha i ́ v \varepsilon \iota$

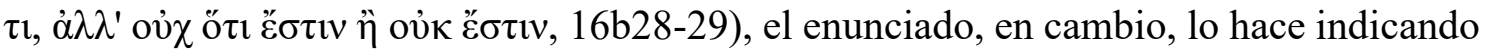

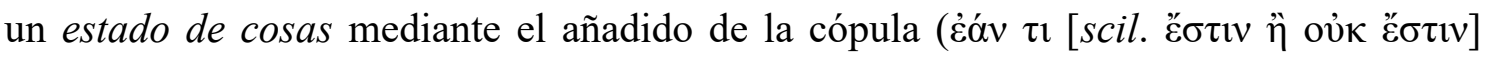
$\pi \rho 0 \sigma \tau \varepsilon \theta \tilde{\eta ̣}, 16 b 30$; cfr. también 16a15, a18). A la primera manera de significar Aristóteles

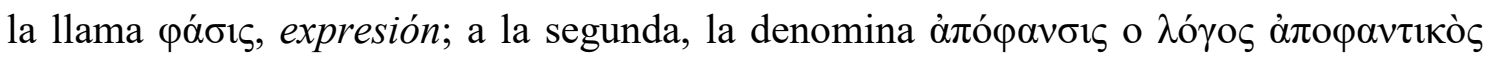
(17a2), que suele traducirse como enunciado declarativo, proposición o simplemente aserción. Mientras que al expresar por medio de la voz un nombre, en sus dos funciones

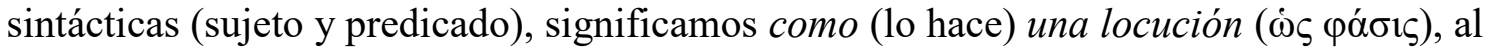
emitir un enunciado declarativo significamos como (lo hace) un enunciado o una aserción

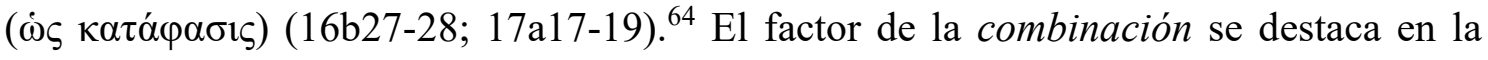

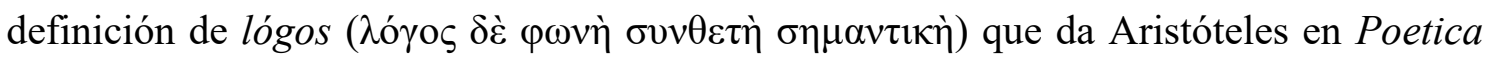
20, 1457a23-24. En efecto, en Poetica (cfr. 1457a24-25) como también en Int. 16a22, 17a4, a8, a11, a17, etc.) Aristóteles admite combinaciones (más laxas) entre partes de un lógos que no dan como resultado propiamente enunciados (sentido estricto de lógos), y de las cuales resultan frases ("caballo salvaje") y definiens ("animal bípedo"), junto a otras combinaciones (en cierto sentido más estrictas) que conforman unidades semánticas de otro tipo. Al primer tipo de expresiones (frases, definiens, pero también nombres y verbos que por sí mismos significan algo) Aristóteles las aclara en De Interpretatione

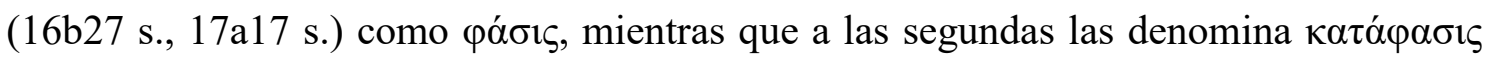
(enunciados tanto afirmativos como negativos). Tanto una frase y un definiens como también un enunciado tienen en común, sin embargo, el hecho de poseer un significado único conjunto, ${ }^{65}$ del cual carece una mera lista de palabras. ${ }^{66}$

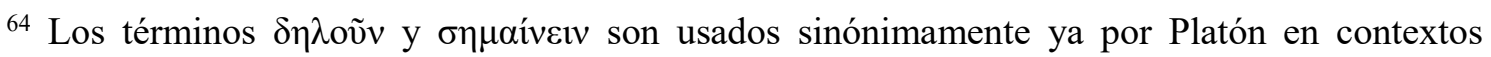
similares (cfr. Cra. 393d4-5, 422ce, 428e, 431d5-c2; Tht. 202b4-5; Sph. 261e5-6). También se retrotrae a Platón (Sph. 262d2-6) la distinción entre nombre y enunciado declarativo.

${ }^{65}$ Aristóteles explica la unidad característica de los enunciados declarativos mediante la condición de que el predicado se dice de un sujeto, y ambos tienen un significado unitario (cfr. Int. 8, 18a12: $\left.\tilde{\varepsilon} v \kappa \alpha \theta^{\prime} \dot{\varepsilon} \vee o ̀ c\right)$. Esto no parece suficiente para diferenciar unidades enunciativas más laxas (i.e. accidentales, e.g. hombre culto) y más estrictas (i.e. esenciales, e.g. animal bípedo); aunque Aristóteles tampoco parece interesado en esto aquí. Tampoco recibe aquí un tratamiento especial la unidad del definiens, para el cual Met. Z 4, Z 12 y H 6 reclaman una unidad fuerte que rechaza la predicación de una cosa a otra, y que debe distinguirse además de la unidad muy débil conformada por un mero conjunto de palabras (cfr. APo. II 10, 93b35-37; Po. 20, 1457a28-30). Para una discusión, cfr. Weidemann, Peri Hermeneias, pp. 194-197.

${ }^{66}$ Cfr. Weidemann, Peri Hermeneias, pp. 188 ss., traduce el sentido laxo de $\lambda$ ó ${ }^{\circ}$ s por Wortgefüge (combinación o entramado de palabras) y el sentido estricto por Satz (enunciado o proposición). 
Es característico de la manera de significar propia del enunciado declarativo el hecho de que tal clase de enunciado tiene un valor de verdad, es decir, muestra cómo es algo predicando una cosa de otra ( puede hacerlo con verdad o falsedad, ya que la combinación o unión -o bien la separación- que tal enunciado establece puede corresponder a cómo son las cosas, o no. La afirmación y la negación son las dos maneras de declarar: afirmando, un predicado se

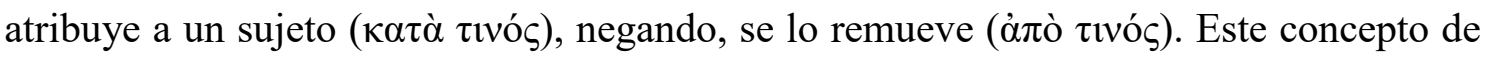
verdad se expresa en 17a26-29, donde Aristóteles indica claramente que el valor de verdad depende de las dos maneras en que se puede enunciar algo, i.e. afirmando o negando (17a30-31; cfr. también Met. E 4, 1027b20-23; $\Theta 10,1051 b 3-5) .{ }^{67}$ En efecto, su tesis es que:

Puesto que es posible | declarar que lo que es, no es, y que lo que no es, | es, como también declarar que lo que es, es, y que | lo que no es, no es [...], | será posible tanto negar todo lo que alguien afirmó, | como también afirmar todo lo que alguien negó (17a26-31) (Trad. Mittelmann, con leves modificaciones) ${ }^{68}$

En 16a9-11, Aristóteles deja en claro que el valor de verdad pertenece a la intelección que articula esa estructura predicativa que tiene como correlato un estado de cosas; es

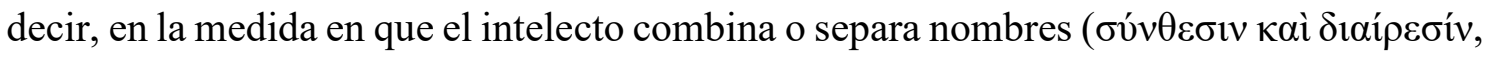
16a12), lo inteligido es necesariamente o bien verdadero o bien falso. ${ }^{69}$ Aristóteles trae a

${ }^{67}$ Otros tipos de enunciados, aludidos en Int. 17a4-6 (e.g. ruego, pedido, orden, etc.; se clasifican en Po. 19) no tienen esa característica.

${ }^{68}$ Remitiéndose a Klaus Oehler, Die Lehre vom Noetischen und Dianoetischen Denken bei Platon und Aristoteles. Ein Beitrag zur Erforschung des Bewusstseinsproblem in der Antike, Hamburg: Meiner, 1985², pp. 151-158, 170-172, 176-186 [Lehre], Weidemann, Peri Hermeneias, pp. 154 s. sugiere que la noción de verdad vinculada a la nóesis o captación de las cosas absolutamente simples (Met. E 4, 1027b27-29; @ 10, 1051b17-1052a4; De An. III 6, 430a26-b6) no es tenida en cuenta dentro del marco del interés lógico definido en De Interpretatione. Los indivisibles aristotélicos son objeto de una intelección que capta conceptos simples, y tales conceptos, por el mismo hecho de ser simples, no pueden ser falsos. En ese sentido, ellos son siempre verdaderos. En cambio, De Interpretatione priva a los nombres y los pensamientos sin combinación de todo valor de verdad (16a10, a15-16). En cualquier caso, De An. 430b1-3 (Met. $\Theta$ 10, 1051b2-3) también admite que sólo la combinación y la separación hacen posible lo que De Interpretatione identifica como valor de verdad. Met. $\Theta 10,1051 \mathrm{~b} 21-22$ sugiere que verdadero y falso no se aplican en el mismo sentido a las cosas combinadas y a las cosas sin combinación. Con relación a estas últimas, verdadero quiere decir tomar contacto y enunciar; falso, correspondientemente, ignorar (1051b24-25). Para un tratamiento de la verdad en Aristóteles, cfr. Paolo Crivelli, Aristotle on Truth, Cambridge: Cambridge University Press, 2004, especialmente pp. 82 ss. (sobre Int. 1), pp. 234-237 (sobre Met. $\Theta 10$ ).

${ }^{69}$ Verdadero y falso se aclaran en Int. 6; cfr. también Met. Г 7, 1012a1-5; E 4, 1027b20-25; @ 10. $\mathrm{Si}$ lo que se atribuye o remueve se indica con un predicado, es plausible que el uso de es en pasajes como 16a17-18 (es o no es se agregan a un nombre) sea incompleto y tenga sentido predicativo, 
colación en este contexto (16a16-18) los nombres de ficción (capricervo) precisamente para aclarar que, a pesar de que esos nombres no designan algo real (cfr. APr. I 38, 49a24; APo. II 7 92a5-8), no son falsos ya que verdad y falsedad sólo son posibles cuando hay combinación. ${ }^{70}$ Capricervo indica algo, aunque quizá no plenamente, como sí lo hace un nombre de clase natural; pero, de cualquier manera, lo relevante en este punto es que ni los nombres de ficción ni tampoco los que significan plenamente clases naturales designan un estado de cosas, y por lo tanto, ambos están privados de un valor de verdad.

\subsection{Nombres aristotélicos y otros nombres}

Dentro del campo de los nombres, en general, Aristóteles establece una tripartición. Él distingue nombres genuinos o de clase (hombre) (simples y compuestos) respecto de nombres indefinidos (no hombre; Int. 3, 16a29-32; 10, 19b8-9) y de otros sin referencia o de ficción (capricervo). Los nombres aristotélicos son nombres o términos de clase, en la medida en que sólo éstos sirven para designar ciertos objetos que tienen en común determinadas características. Por ello, en Sophistici Elenchi 1, 165a6-12 Aristóteles puede reclamar que un mismo nombre se aplica a muchas cosas, y mantiene que el lenguaje representa la realidad, perfilando una semántica realista que básicamente sostiene la convicción de que la característica semántica de los nombres nos permite

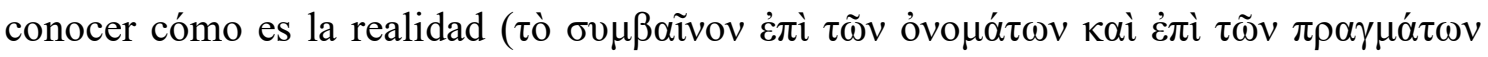

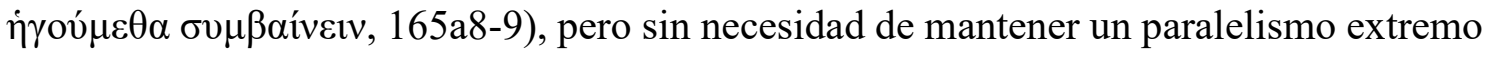

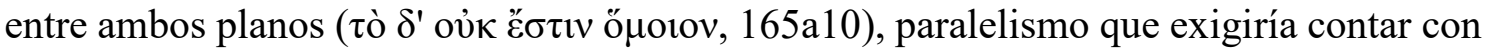
tantos nombres como cosas.

A los nombres indefinidos, en cambio, no está asociado un concepto, ya que no hay algo determinado que sea no hombre; por lo tanto, no corresponde estrictamente asignarles un significado ya que no hay propiamente clases indefinidas. Los nombres indefinidos están al borde de la categoría nominal; tan es así que Aristóteles llega a homologarlos a ruidos, cosa que estrictamente no son. Ahora bien, desde un punto de

a pesar de que su gramática sugeriría un sentido existencial. Lo mismo debería valer para tò

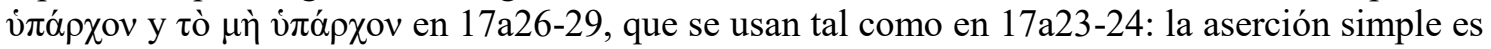

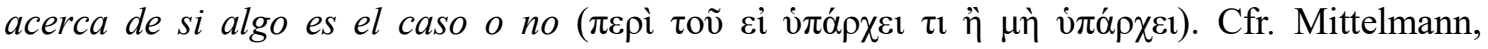
Categorías, p. 151 n. 5.

${ }^{70} \mathrm{Me}$ decanto así por la segunda interpretación de capricervo que consigna Weidemann, Peri Hermeneias, p. 156 (que aparentemente fue la de Pacius). 
vista gramatical, los nombres indefinidos pueden desempeñarse como sujetos oracionales, pero semánticamente no cuentan como nombres estrictos por las razones antedichas. Morfológicamente, los nombres indefinidos se componen de una negación -que no es propiamente una negación proposicional (16a31, 20a31-36)- y un nombre de clase; pero la operación de la partícula negativa es la de eliminar la determinación que conlleva el nombre de clase; es como si dijéramos: "Eso que está ahí no es de tal tipo", pero sin especificar nada más ni añadir información alguna sobre qué otro tipo de cosa podría ser eso.

De tal manera, contrariamente a la opinión de Weidemann, los nombres negativos no pueden compararse a nombres compuestos. Es posible que los nombres indefinidos puedan tener sólo contextualmente un significado; como cuando en una situación determinada, donde ya se cuenta con medios para identificar los objetos de un dominio bien definido - es decir, donde ya usamos medios lingüísticos para designar objetos que son miembros de una clase-, se usa una expresión negativa de ese tipo para individualizar un conjunto respecto de otro (e.g. "(animales) no humanos" se usa de esa manera). Pero, como queda claro por este ejemplo, ese "significado" sólo contextual de los nombres indefinidos descansa en el uso, tácito o no, de nombres plenos. ${ }^{71}$ De otra parte, los nombres ficticios son en cierta manera significativos aun cuando carezcan de referencia; el significado de los nombres ficticios que tiene en cuenta Aristóteles está fijado por un contexto narrativo, aunque dicho contexto no puede confundirse con la existencia de objetos reales portadores de propiedades, que son los referentes de nombres plenamente significativos.

No es seguro que Aristóteles disponga de distinciones suficientes para captar las diferencias que existen entre nombres simplemente no referenciales (e.g. "vacío", "Quimera") y nombres que carecen de una referencia a algo determinado y unitario precisamente porque tienen una mera una unidad nominal ("vestido" como nombre para algo compuesto carente de unidad, como hombre-caballo). Obviamente, carecer de referencia no es lo mismo que hacer referencia a múltiples cosas que carecen de un rasgo común entre sí. Sin embargo, estos dos tipos de nombre tienen en común el hecho de que no son nombres genuinamente aristotélicos ya que no cumplen con la condición establecida en 16a6-8 de estar asociados a un pensamiento que representa algo real. Tal

${ }^{71}$ Para una discusión, cfr. Weidemann, Peri Hermeneias, pp. 170 s.; y más extensamente Montanari, Peri Hermeneias, vol. II, pp. 149 ss. 
como surge de esta consideración, un requisito ulterior de los nombres aristotélicos es que su referencia esté constituida por algo apropiadamente unitario, como una clase natural (Cat. 2, 1b3-7), o, en el caso de un nombre de artefacto ("casa"), designar un objeto provisto de una funcionalidad suficientemente unitaria como para asegurar la referencia simple y el significado de ese nombre.

Mientras que es posible aceptar que en De Interpretatione el significado de un nombre genuinamente aristotélico se explica por las condiciones enumeradas por Charles -básicamente, el significado de un nombre genuinamente aristotélico se individualiza por medio de la aprehensión consciente de la clase de objeto extramental que causa el contenido de la representación mental a la cual el nombre se asocia- ${ }^{72}$ creo que los nombres no genuinos (i.e. de entidades de ficción, de objetos reales compuestos carentes de la unidad apropiada) deben seguir otra ruta para adquirir su significado peculiar. Por el contrario, Charles sugiere que la significación inmediata de un nombre genuinamente aristotélico -i.e. la significación determinada por el contenido del pensamiento, significación que, para él, se registra en el primer estadio de la investigación (i.e. aquel en el cual no se conoce más que el mero significado, sin saber aún si hay algo en el mundo especificado de esa manera)- comparte con la significación de los nombres de ficción (“capricervo") un rasgo fundamental. Pues, según Charles, conocer el significado inmediato de los nombres de clases naturales no implica conocer cómo se fijó el contenido del pensamiento con el cual el nombre está asociado ni cuál es la naturaleza del objeto externo correlacionado. ${ }^{73}$

En resumen, y aun contando con la muy limitada justificación que puedo ofrecer del alcance de la interpretación que aquí estoy suscribiendo en virtud de que no me ocupo de la semántica de Analíticos Segundos, podría contrastar mi propia lectura con la de Charles, en este aspecto, de la siguiente manera: Charles propone una misma ruta de fijación del significado para los nombres de clase y para los de ficción (que aquí tomo en

${ }^{72}$ Cfr. Charles, Meaning and Essence, p. 101. Su discusión (id., caps. 2-3, pp. 78 ss., cap. 4, y especialmente pp. 87-109) está condicionada por su propia distinción de los tres estadios de la investigación de $A P o$. II (1-2, 7-10) y depende de que se acepte la proyección de los mismos en De Interpretatione.

${ }^{73}$ Para su distinción entre significado inmediato y mediato, en la que interesantemente tiene impacto la variación textual de Int. 16b6, cfr. Charles, Meaning and Essence, p. 83. Él acepta que el significado mediato de un nombre está determinado por las sustancias a las cuales el nombre refiere y que causan, mediante la transferencia de la forma, un cierto pensamiento, al cual el nombre se asocia convencionalmente. Para la crítica de Charles a la interpretación fregeana de este tema en Aristóteles, cfr. id., pp. 104-109. 
representación de los que llamo, respectivamente, nombres genuinamente aristotélicos y nombres aristotélicos no genuinos), a la vez que distingue (por recurso a los estadios de la investigación) la manera en que los primeros adquieren un compromiso existencial. Por el contrario, mi propuesta es que en De Interpretatione se da una explicación sobre el significado que propiamente es aplicable a los nombres de clase. Según esa explicación, la fijación del significado conlleva un compromiso existencial y la capacidad epistémica del usuario que consiste en ser capaz, bajo condiciones epistémicas favorables o ideales, de dar una definición del objeto designado. Bajo condiciones epistémicas menos favorables, quien usa correctamente un nombre de clase dispone del conocimiento de algún sucedáneo o reemplazo apropiado (por ejemplo, una opinión bien acreditada) de la definición del objeto. Por otro lado, los nombres no genuinamente aristotélicos están de alguna manera al borde de la categoría nominal (aunque sin llegar a carecer completamente de significado; infra 6.4.), y definitivamente no representan el caso sobre el cual De Interpretatione se interesa en ofrecer una explicación. ${ }^{74}$

\subsection{Voces significativas y otros sonidos}

La explicación y los compromisos aristotélicos acerca del significado también pueden entenderse más claramente si se contrastan los nombres genuinamente aristotélicos con

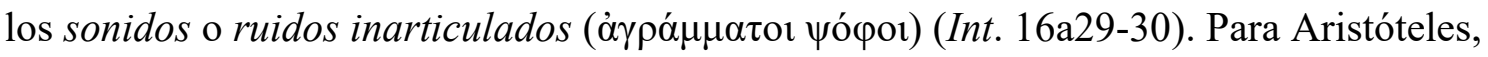
el lenguaje humano se compone de partes elementales que se articulan conformando un sistema idiomático, es decir, un sistema codificado de fonemas y grafemas. Aristóteles contrapone los nombres, desde el punto de vista de su específica función semántica, a la diferente función comunicativa que cabe reconocer a otras voces naturales, como gruñidos, graznidos, gritos, y otras expresiones sonoras inarticuladas de índole similar que pueden emitir tanto animales humanos como no humanos. Un grupo de estas últimas manifestaciones puede convertirse en vehículos de emociones animales; sin embargo, aun cuando ostenten una fuerza expresiva y comunicativa de tal índole, en especial al integrarse a contextos de interacción con otros miembros de la especie, desde el punto de vista aristotélico tales expresiones vocálicas naturales no cuentan como expresiones

\footnotetext{
${ }^{74}$ En tal sentido, los nombres de ficción y quizá también los negativos y los compuestos sin un objeto apropiadamente unitario son, con respecto a los nombres genuinos, casos de contraste antes bien que casos rectores en la explicación del significado. Aun menos le interesa a Aristóteles allí ofrecer una teoría elaborada del significado para los pronombres, demostrativos y adverbios.
} 
genuinamente representacionales ni califican como lo que especifica al lenguaje humano. ${ }^{75}$ Esto se pone de manifiesto cuando Aristóteles describe este tipo de sonidos:

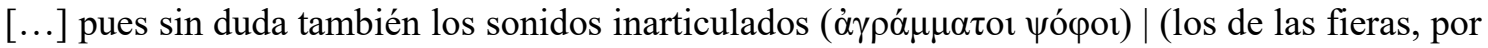
ejemplo) indican ( $\delta \eta \lambda$ oṽ $\sigma i ́)$ algo, y ninguno de ellos es un nombre (16a28-29; trad. Mittelmann).

No es un aspecto meramente externo a los sonidos inarticulados o ruidos (vocálicos)

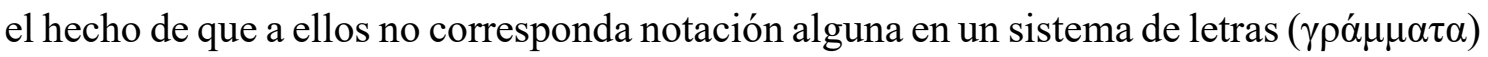
-un abecedario-, las cuales, precisamente, codifican a través de una notación las unidades vocálicas o fonemas ( $P A$ II 16, 660a3-7) ${ }^{76}$ Esto quiere decir que no hay una gramática que estructure los sonidos emitidos por animales no humanos; a su vez, la ausencia de una gramática para tales sonidos se explica por su deficiencia semántica intrínseca. Mientras que los animales humanos asociamos mediata y convencionalmente fonemas a conceptos, sirviéndonos de la articulación de los fonemas en un abecedario -formado por símbolos, en el sentido de De Interpretatione 16a28-, ${ }^{77}$ los animales no humanos, por su parte, realizan una producción sonora de otro tipo, para lo cual recurren a una asociación

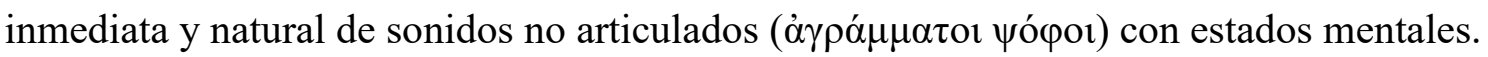
Desde un punto de vista aristotélico, esos estados mentales, a los que no corresponde una gramática en el orden de los sonidos, no pueden contarse como provistos de contenido conceptual.

Desde un punto de vista aristotélico, entonces, la falencia semántica de los sonidos vocálicos emitidos por animales no humanos - o también el lloriqueo de los infantes $-^{78}$

\footnotetext{
${ }^{75}$ Aristóteles restringe a los humanos el uso del lenguaje -en el sentido de un sistema de sonidos articulados convencionalmente asociados a conceptos- en HA IV 9, 536a33-b2; Pol. I 2, 1253a815. Aquellos pájaros que poseen un "lenguaje" articulado ( $H A$ II 12, 504b1-3) no poseen, por eso mismo, propiamente un lenguaje humano.
}

${ }^{76}$ R. Zirin, "Inarticulate Noises," ["Noises"] en Ancient Logic and Its Modern Interpretations, John Corcoran (ed.), 23-5, Dordrecht/Boston: Reidel, 1974, aclara la noción de articulación

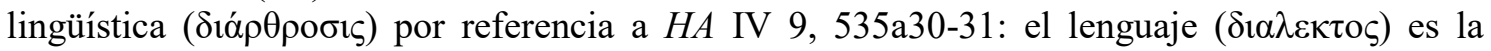
articulación de la voz -la cual se produce, a su vez, en la laringe- por medio de la lengua. Zirin insiste en que $\dot{\alpha} \gamma \rho \alpha ́ \mu \mu \alpha \tau o \zeta$ debe entenderse como lo opuesto a $\dot{\varepsilon} \gamma \gamma \rho \dot{\alpha} \mu \mu \alpha \tau o \zeta$, que según (Ps.-Plat.) Def. 414d califica la peculiar articulación de la voz humana. Si se acepta esta última sugerencia, à $\gamma \alpha \alpha ́ \mu \mu \alpha \tau o \varsigma$ puede tomarse como un término técnico para calificar la voz no humana.

${ }^{77}$ En Int. 16a3-4, en cambio, las voces humanas se calificaban como símbolos precisamente en virtud de poseer como contraparte unas afecciones del alma provistas de contenido conceptual. Las voces simbolizan esas afecciones, en cuanto que, como su contraparte, "encajan" con ellas y permiten reconocerlas. Para este uso de "símbolo", cfr. Pl. Smp. 191d3-5.

${ }^{78}$ Zirin, "Noises," p. 24. Pépin, " $\mathrm{YMMBO} \Lambda \mathrm{A}$," 38 ss. (n. 52), no puede estar en lo cierto, al suponer que Aristóteles equipara el significado de una voz humana plena con el que puede tener el balido de un cordero que indica hambre. En definitiva, esta interpretación depende de la 
no se explica por el hecho de que tales voces sean convencionales o naturales, sino, en cambio, por el hecho de que tales sonidos no expresan estrictamente un significado, es decir, no captan las formas de las cosas, que son los correlatos externos de los significados del lenguaje humano. ${ }^{79} \mathrm{La}$ expresión de significado explica la índole convencional o natural de los signos. Una vez establecido esto, es posible clasificar los sonidos inarticulados de los animales entre los signos naturales, asimilándolos, en su manera de funcionar, a una formación nubosa que indica lluvia.

El sentido técnico de $\varphi \omega v \eta ́$ (voz) en De Interpretatione, que en cuanto $\varphi \omega v \eta ̀$

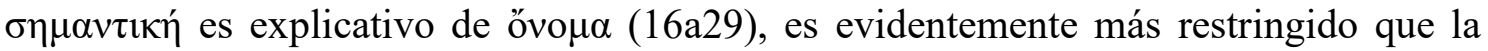
clasificación de De Anima II 8, 420b5-6, aunque, probablemente, ambas determinaciones no son contradictorias, sino, de alguna manera, complementarias, siendo la de $D e$ Interpretatione la propiamente semántica. En el pasaje de De Anima, la voz se determina

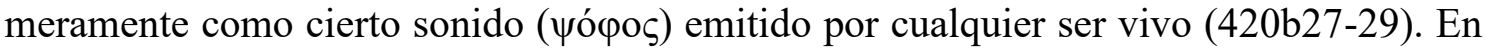
cambio, en De Interpretatione Aristóteles considera los sonidos vocálicos emitidos por animales privados de razón como meros sonidos o ruidos que no cuentan como voces -nombres aristotélicos- en el sentido técnico de 16 a19 y 16 a29 precisamente en virtud de que tales sonidos no son vehículos de significado. Similarmente, en la consideración

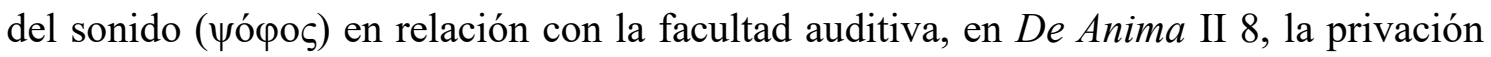
semántica que afecta al sonido que emiten ciertos animales no humanos no se explica apelando a algún factor físico -como puede serlo un medio de transmisión inadecuado del sonido-.

En sentido lato, voz se llama en De Anima a todo sonido emitido por un animal (420b13); pero con ese criterio cualquier cosa que produce un golpe en un medio de

controvertible suposición teórica según la cual el significado no consiste más que en dar a conocer (manifestar, expresar, indicar) un estado mental del emisor. Pero esta suposición priva de sentido al carácter convencional que tienen los nombres aristotélicos, así como también a la correlación de los mismos con una facultad como el intelecto. La interpretación de Pépin sólo puede mantenerse si se toman las voces y las afecciones del alma involucradas en el pasaje de De Interpretatione en un sentido lato, que abarca emociones y sonidos no articulados. En contra de esa lectura he tratado de mostrar que la focalización en el término técnico de nombre y enunciado declarativo, que son el verdadero objeto de la sección lingüística introducida por las líneas iniciales de este tratado, hacen suponer que Aristóteles se refiere a ambos ítems en un sentido restringido, al cual corresponden los conceptos que se forman a través del intelecto.

${ }^{79}$ Para Kretzmann, "Spoken Sound," p. 17, en cambio, establecer una notación convencional con una estabilidad equiparable a la de un abecedario sería una condición suficiente para que cualquier sonido inarticulado se convierta en un nombre aristotélico. Sin embargo, la codificación convencional es, a mi juicio, una condición necesaria, pero no suficiente, en la medida en que, como tal, depende del factor externo -la estructura objetiva de las cosas-. 
transmisión adecuado (e.g. el aire o un metal) podría producir una voz (420b14-16). En este contexto, Aristóteles introduce una interesante consideración teleológica (420b17 ss.) que ayuda a comprender mejor su noción de significado: la naturaleza se sirve del aire inspirado por los animales -i.e. el aliento- para dos funciones distintas: tal como nos servimos de la lengua tanto para degustar los alimentos como también para hablar ( $\tau$ ñ

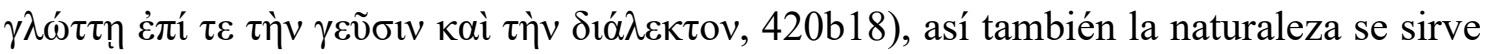
del aire tanto para producir el necesario calor interno en un ser vivo -algo que es mecánicamente necesario para que haya un motor y un poder que cause el movimiento del animal (cfr. MA 10, 703a9-22; De Resp. 470b24 ss.)- como también para articular la

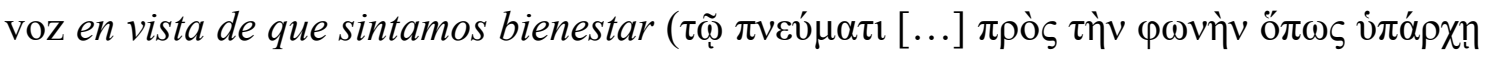

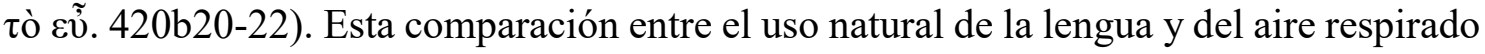
o aliento es relevante para aclarar el carácter y uso significativo de los sonidos emitidos mediante el sistema vocálico humano con sus distintos órganos. En efecto, es posible que con esa comparación Aristóteles intente señalar, primero, que sólo algunos animales utilizan la lengua y el aire para emitir sonidos significativos; y, segundo, que los animales que se comportan de esa manera son precisamente aquellos que están orientados a la búsqueda de bienestar. En De Anima 420 b17 ss., Aristóteles afirma que algunos animales tienen la capacidad de servirse de la lengua no sólo para degustar los alimentos, sino también para la interpretación del pensamiento ( $\dot{\eta} \delta^{\prime} \dot{\varepsilon} \rho \mu \eta v \varepsilon i ́ \alpha, 420 b 19-20$; cfr. también $P A$ II 16, 660a35), es decir, para la expresión lingüística del mismo, lo que ellos hacen en vista de su propio bienestar. Creo que la posibilidad de atribuir a Aristóteles la tesis de que la invención y el manejo del lenguaje están vinculados a objetivos (la comunicación intersubjetiva mediante la interpretación del pensamiento, la búsqueda de bienestar en la vida en una pólis) que pertenecen a un orden distinto de aquel en el cual se inscriben sus consideraciones fisiológicas sobre los sonidos en animales humanos y no humanos, se refuerza cuando, un poco más abajo en este mismo pasaje (420b29-33), él retoma el sentido técnico y estricto de voz como sonido significativo.

El enfoque fisiológico sobre la voz, que predomina en pasajes como el que acabo de considerar de De Anima (cfr. también HA IV 9), le permite a Aristóteles trazar explícitamente la distinción entre un mero sonido vocálico, por un lado, y la voz significativa, propia de animales racionales, por el otro. Se trata de una distinción que él establece en cuanto a la forma de cada una de las dos voces allí involucradas, ya que, materialmente, ambas comparten la caracterización genérica de ser voces, i.e. el impacto 
del aire inhalado que se golpea contra la tráquea por causa de la intervención del alma motriz en esa parte corporal. En De Interpretatione, en cambio, si bien la distinción entre el componente material y formal de la voz no está completamente ausente -en efecto, allí también distingue Aristóteles entre los sonidos vocálicos de las bestias y las voces significativas de los humanos, siendo que ambas producciones sonoras pueden compartir la misma base fisiológica-, ella no está en el foco ya que la discusión aristotélica aborda allí el significado y el pensamiento conceptual.

Lo que sugiero es que el manejo de sonidos significativos -es decir, la noción semántica de voz- por parte de cierta especie de animales está inextricablemente ligada a su existencia política, es decir, a la clase de comunidad en la que tal clase de animales

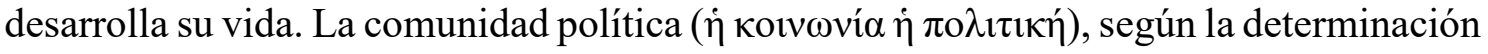
de Politica I 1-2, es aquella clase de comunidad que, estando genéricamente constituida en vista de un bien (1252a4), se constituyó con el fin de subsistencia y preservación de la vida de sus miembros, y que tiene como fin específico y natural el bienestar ( $\gamma 1 v o \mu \varepsilon ́ v \eta$

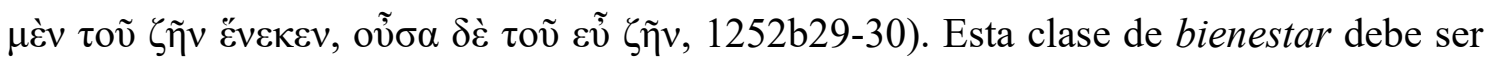
claramente de otro tipo que la mera satisfacción de necesidades corporales, ${ }^{80}$ si es que ese bienestar político está vinculado a otras necesidades y a acciones correspondientes que se emprenden para su satisfacción. En síntesis, mientras que hay animales no humanos que se sirven de la $\varphi \omega v \eta ́$, en la medida en que perciben estados corporales, como placer y dolor, a los humanos resulta peculiar ('íiov, 1253a16) servirse del $\lambda o ́ \gamma o \varsigma$ para expresar lo conveniente, lo justo (y sus contrarios), y otras cosas de tal índole (1253a10-18). ${ }^{81}$ Podemos suponer que entre esta última clase de cosas, intrínsecas a animales racionales y políticos, se cuentan los nombres aristotélicos. ${ }^{82}$

${ }^{80}$ El bienestar corporal es también un fin de todos los animales dotados de sentidos, y se distingue

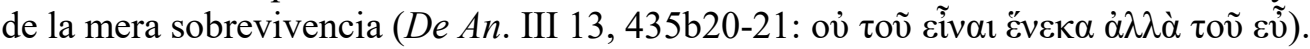

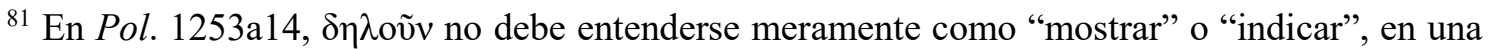

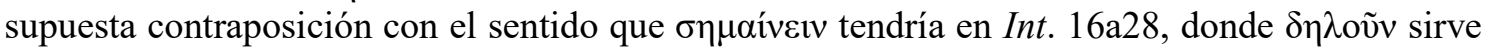
para especificar la función que desempeñan las expresiones vocálicas de animales no humanos.

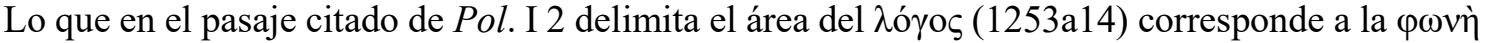

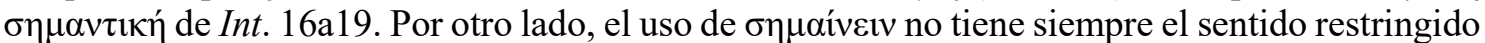

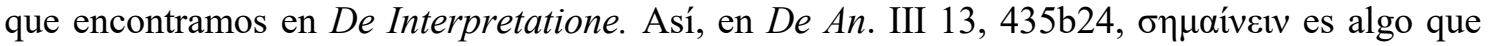
pueden alcanzar, en general, los animales dotados de capacidad auditiva, lo que obviamente no se restringe a los racionales. Sens. 1, 437a9-17 afirma que la facultad auditiva es una condición necesaria -aunque, obviamente, no suficiente-para el pensamiento ( $\varphi \rho o ́ v \eta \sigma ı v)$ y el razonamiento

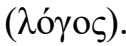

${ }^{82}$ Para una valoración de esto, cfr. Pierre Aubenque, "Aristote et le langage," (1967) reed. en Problèmes aristotéliciens, I Philosophie théorique, 11-30, Paris: Vrin, 2009. 


\section{Significado e intelecto en De Anima}

En este último conjunto de apartados me dedicaré a discutir y justificar la manera en que he interpretado el sentido de ó $\mu$ oı́ $\mu \alpha \tau \alpha$ en De Interpretatione 16a7. Mi objetivo filosófico consistirá en intentar exonerar a Aristóteles de las imputaciones que devienen de tomar dicho término en el sentido literal -y mayormente aceptado por los intérpretesde una semejanza producida a través de imágenes mentales, a las cuales se asocia la controvertida idea de que es precisamente a través del contenido interno de tales imágenes como logramos proveer de referencia a nuestras palabras y así establecemos contacto con el mundo externo.

Con ó $\mu$ otต́$\mu \alpha \tau \alpha$, que es usual traducir por semejanzas, Aristóteles hace alusión en 16a7 a la manera en que las afecciones del alma ( $\pi \alpha \theta \eta \dot{\eta} \mu \alpha \tau \alpha \tau \tilde{\eta} \varsigma \psi v \chi \tilde{\eta} \varsigma)$ se vinculan con las cosas reales o ítems extramentales $(\pi \rho \alpha ́ \gamma \mu \alpha \tau \alpha)$. Más precisamente, ó $\mu$ oí $\omega \mu \alpha$ expresa qué son con respecto al mundo nuestros pensamientos. Todo parece indicar que tales afecciones están provistas de lo que llamamos contenido conceptual, algo que conlleva una marcada impronta intelectualista en la aprehensión que Aristóteles hace de la mente o el pensamiento envuelto en ese contexto, ya que estados emocionales o sensaciones, por sí mismas, no se contarían entre las afecciones del alma relevantes. ${ }^{83}$

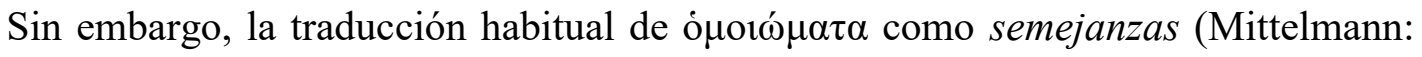
"semejanzas"; Ackrill: "likenesses"; Weidemann: "Abbildungen") -junto a otros

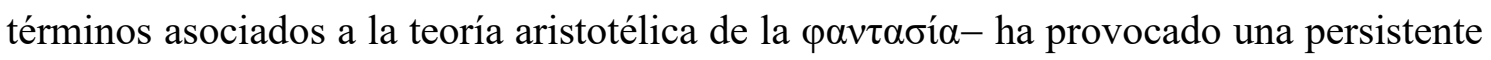

${ }^{83}$ Más allá de cuál sea la interpretación que se dé a la relación entre intelecto e imaginación, corrientemente se acepta que en Int. 16 a10 y a14 Aristóteles debe restringir las afecciones del alma relevantes en ese contexto a las que corresponden a la parte intelectiva del alma. Cfr. e.g. Charles, Meaning and Essence, p. 82; Weidemann, Peri Hermeneias, pp. 135 s., 140 ss., 151 ss. Weidemann acepta la sugerencia de Polansky y Kuczewski, "Speech and Thought," p. 56, acerca de que las copias o imágenes que se forman en el alma no son propiamente imágenes ni contenidos sensoriales, sino más bien pensamientos o conceptos. Polansky y Kuczewski, "Speech and Thought," advierten acertadamente que la interpretación de las afecciones del alma en términos de imágenes mentales difícilmente puede ser coherente con el carácter universal ( $\tau \alpha \hat{\tau} \tau \grave{\alpha} \pi \tilde{\alpha} \sigma \mathrm{l}$ ) que es propio de las afecciones del alma que Aristóteles tiene a la vista en Int. 16a8. No creo que pueda haber una contradicción entre, por un lado, aceptar que el uso de nombres aristotélicos implica un detenimiento, en el sentido de la captación de un contenido conceptual, y, por otro, reclamar que ese contenido conceptual se forma en la mente como efecto de la acción causal que ejerce un objeto externo, en la medida en que éste es inteligido. Para esta última lectura, cfr. Charles, Meaning and Essence, pp. 80 ss. Sobre la posible referencia a De An. que hace 16a8-9, Weidemann, Peri Hermeneias, pp. 151 ss., informa sobre distintas opiniones tradicionales; ya Amonio y Boecio identificaron pasajes de De An. donde podría encontrarse el tratamiento sobre los pensamientos aludidos mediante el demostrativo $\tau o v ́ \tau \omega v$ en $16 \mathrm{a} 8$. 
confusión en la interpretación de la facultad envuelta en el significado. La interpretación dominante supone que Aristóteles explicaría el significado y los conceptos en términos de una semejanza estricta y literal, la cual aseguraría la intencionalidad mental, es decir, que tal pensamiento sea efectivamente el pensamiento de algo que existe, y que en el pensamiento se representan las cosas externas tal como son. Sin embargo, esa lectura tiene un apoyo bastante exiguo que casi se limita a la traducción literal de ó $\mu$ otó $\mu \alpha \tau \alpha$ y a la asociación de la semejanza con la facultad de la $\varphi \alpha v \tau \alpha \sigma i ́ \alpha$ y, por intermedio de ésta, con la clase de imágenes que se producen en la senso-percepción. Con este complejo cuadro de la psicología aristotélica inyectado en el trasfondo de De Interpretatione, los intérpretes suelen explicar los significados de los nombres aristotélicos como vinculados a las imágenes mentales. En vista de la desproporción entre, por un lado, una interpretación comprometedora y controvertida y, por otro lado, la base textual exigua que la sostiene, puede ser aconsejable explorar una lectura alternativa, teóricamente más fructífera e interpretativamente coherente, además, con la lectura general de la relación entre significado e intelecto que he insinuado en distintos momentos a lo largo de este artículo.

El deslinde del programa semántico de De Interpretatione respecto del programa psicológico de De Anima debe comenzar señalando un aspecto parcialmente común a ambos tratados. En efecto, el carácter conceptual, que le he atribuido a las afecciones del alma en De Interpretatione, es el mismo que focaliza De Anima III 4, 429a10-11, al indicar que hay una facultad del alma por medio de la cual conocemos y pensamos

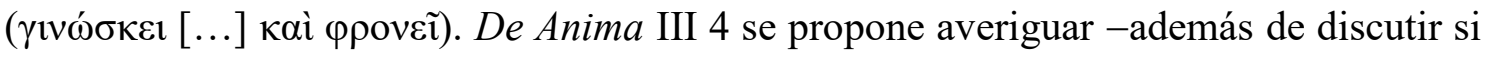
el intelecto es una facultad conceptualmente separable de las inferiores- cómo llegamos

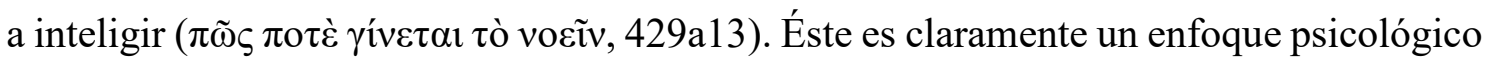
ajeno a la discusión de De Interpretatione, y más allá de las dudas acerca de cuál es el pasaje de De Anima al que haría referencia De Interpretatione $16 a 8-9,{ }^{84}$ me parece bastante claro que la distinción de enfoques y respectivos programas debe explicarse en los términos que he sugerido: por un lado, un enfoque semántico (que incluye cierta hibridez entre gramática y lógica) en De Interpretatione; por otro lado, un enfoque psicológico en De Anima, que se ocupa de explicar cómo ejercitamos nuestras facultades. El hecho de que Aristóteles no se proponga discutir en sede semántica-cuyos temas se

\footnotetext{
${ }^{84}$ Es posible admitir que Int. 16 a8-9 se refiere generalmente a distintos pasajes contenidos en De
} An. III 3-8. 
enuncian en las dos primeras líneas del tratado, i.e. 16a1-2- el trasfondo psicológico de la representación puede explicar la brevedad con la cual él se expide sobre las representaciones en 16a6-9. ${ }^{85}$ Aunque el aspecto psicológico de ninguna manera debe eliminarse de la teoría aristotélica del significado, Aristóteles está autorizado a focalizar en De Interpretatione 1-6 el carácter semántico-representacional o conceptual de las voces prescindiendo de una discusión acerca del proceso psíquico de formación de las representaciones. En resumen, si bien la semántica de De interpretatione supone una teoría sobre los estados mentales intencionales vinculados al intelecto, no depende de otras suposiciones psicológicas. ${ }^{86}$

\subsection{Conceptos e imágenes}

En la caracterización del nombre como voz significativa, De Interpretatione opera con una noción de significado sólo explicable sobre la base de estados mentales característicos de la facultad intelectiva. Algunas posiciones básicas de De Anima III pueden ayudar a precisar los compromisos envueltos en esa teoría del significado.

Podemos comenzar prestando atención al rasgo de objetividad (que es una característica del significado y de las representaciones mentales envueltas en $D e$ Interpretatione) que Aristóteles le concede al intelecto por contraposición a la imaginación. En De Anima III 3, Aristóteles sostiene que mientras que la imaginación es una afección que depende de nosotros (427b18) -en la medida en que una imagen se

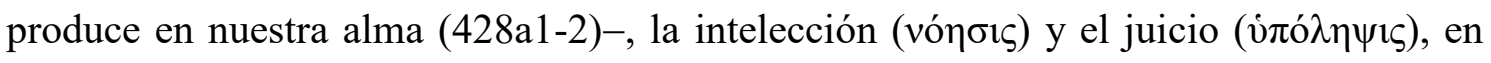
cambio, no tienen ese carácter, sino que son representaciones objetivas, en cuanto que no dependen de nosotros en el sentido anterior (427b20) puesto que el contenido de la intelección y del juicio depende, en cambio, de cómo son las cosas -no de cómo nos aparecen a la manera en que las cosas que nos representamos en la imaginación son meramente tal y como nos aparecen-. En el ejemplo de la imagen del sol en comparación

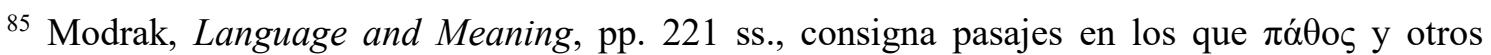
términos de la misma familia en la psicología aristotélica designan estados internos intencionales tanto de carácter emocional como epistémico.

${ }^{86}$ Kapp sugirió que si bien el objeto de la lógica en De interpretatione depende del de la psicología, Aristóteles trata explícitamente como independiente la investigación lógica respecto de la psicológica. Similarmente, Oehler, Lehre, pp. 18 ss., 151 ss. Ya los comentadores antiguos (Simplicio y Boecio; cfr. Weidemann, Peri Hermeneias, p. 153) trazaron una distinción entre lógica y psicología que anticipa esta posición. 
con el tamaño de un pie (428b2-4), la falsedad de la imaginación no se explica, como sucede en otros casos, por una percepción defectuosa (428a14-15), sino que ese ejemplo muestra que es posible combinar dos estados cognoscitivos con un valor veritativo opuesto: una imagen (que nos muestra un objeto tal como nos aparece) y un juicio ( contradice. Esto muestra que no toda imagen o no todo lo que a uno se le aparece es verdadero (

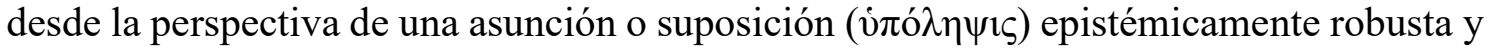
que dispone de correlatos no restringidos a las solas imágenes o apariencias. La característica veritativa de la imaginación como productora de imágenes que son verdaderas o falsas con respecto a cómo son los hechos no implica la combinación de conceptos, que constituye el carácter proposicional de la verdad o falsedad ( $\sigma \nu \mu \pi \lambda$ oк̀े

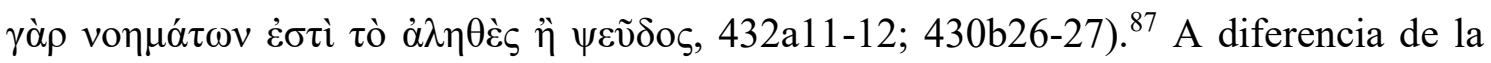
imaginación (y la percepción, de la cual la imaginación depende), el intelecto opera representando estructuras de otro tipo mediante procesos cognoscitivos peculiares ( distinguirse por su carácter conceptual respecto de los contenidos propios de la sensación y de la imaginación.

La senso-percepción, la imaginación y la memoria operan fundamentalmente con imágenes sensibles. El enraizamiento de la imaginación en la senso-percepción se establece en distintos pasajes. En De Insomniis 459a16-17 (cfr. también De An. III 9, 432a31-b2), Aristóteles identifica la imaginación con la percepción; en De Anima III 3, 428b11-16, añade que la imaginación es una especie de movimiento anímico que surge en seres vivos capaces de percibir. La diferencia entre senso-percepción e imaginación radica en que, en el caso de la imaginación, no hay un objeto presente que la produzca a través de un movimiento (o la presencia de ese objeto sensible ante la percepción es defectuosa en comparación con los estándares satisfechos cuando dicho objeto sensible es captado perceptivamente de manera adecuada). La imaginación compensa esa ausencia del objeto mediante la producción espontánea de imágenes mentales ( $(\alpha v \tau \alpha ́ \sigma \mu \alpha \tau \alpha)-$ las

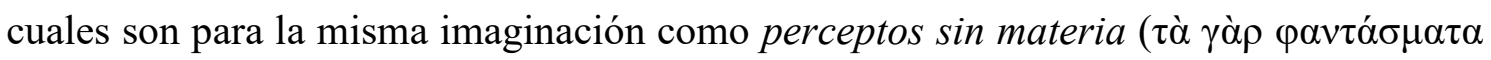

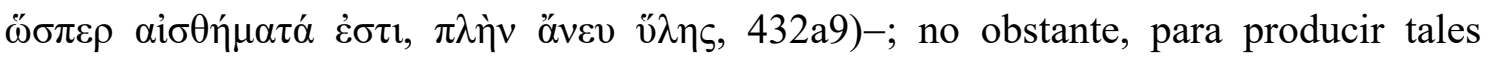

\footnotetext{
${ }^{87}$ Sobre el problema de la mención de los $\pi \rho \tilde{\tau} \tau \alpha$ vớ $\mu \alpha \tau \alpha$ en 432a12, cfr. Wedin, Mind and
} Imagination, pp. 125 ss. 
imágenes se requiere una sensación precedente que pone en movimiento ( $\dot{\eta} \varphi \alpha v \tau \alpha \sigma i ́ \alpha$ òv

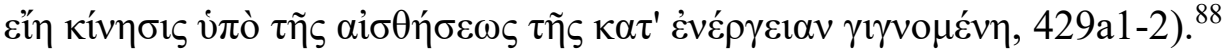

Un claro contraste con estas operaciones cognoscitivas implica la afirmación de $D e$ Anima III 4, 429a28, según la cual el alma es el lugar de las formas; en efecto, esta afirmación implica una correlación entre las formas y la facultad del intelecto. ${ }^{89} \mathrm{El}$ punto de controversia concierne al uso necesario de imágenes para captar las formas por parte del intelecto. Para comenzar, habría que señalar que aun cuando Aristóteles admite que el intelecto humano no capta nunca sus propios correlatos sin imágenes (III 7, 431a1617), pues los humanos no podemos formarnos conceptos sin poseer anteriormente imágenes, él insiste igualmente en que la intelección y sus correlatos propios no se identifican con (ni pueden reducirse a) la imaginación y las imágenes: "Los <conceptos> [vớ $\mu \alpha \tau \alpha]$ no son imágenes, pero no se dan sin | imágenes.” (De An. III 8, 432a13-14, trad. Boeri).

En De Anima III 3 (427b27-29), III 7 (431a14-17) y De Memoria (1, 449b31-450a1), Aristóteles reafirma la tesis de que no es posible inteligir sin imágenes. Este último pasaje merece al menos un breve comentario. Para explicar de qué manera el intelecto se sirve de imágenes, y a la vez en qué sentido se distinguen mutuamente las imágenes y los conceptos, De Memoria 1, 449b31-450a7 recurre a la "locución qua". La idea que allí se expresa es que, al concebir una figura geométrica, el intelecto se sirve de una imagen similarmente a como el geómetra dibuja un diagrama, haciendo caso omiso a la dimensión determinada y particular del diagrama. De manera semejante, quien concibe un objeto geométrico hace caso omiso de los aspectos sensibles (la dimensión determinada de la figura en cuestión) para sólo operar sobre la figura tomada (entre otras propiedades del

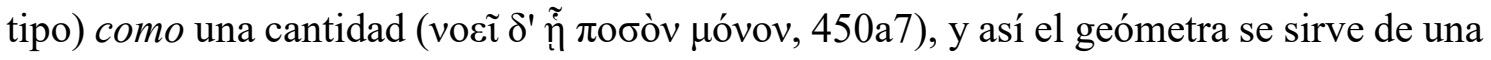
imagen a título de ejemplo con el objetivo de focalizar las propiedades geométricas correspondientes. Esto explica que, en cierto sentido, la afección de la imaginación y la intelección sea la misma (450a1), en la medida en que ambas operan sobre una misma imagen (un triángulo dibujado); pero, en otro sentido, el correlato propio de una y otra no

${ }^{88}$ La memoria opera similarmente produciendo una imagen que es copia del objeto externo

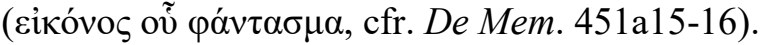

${ }^{89}$ Más abajo (7.2.) considero un poco la segunda restricción, que indica que las formas están en el alma sólo potencialmente. Sobre esto, cfr. Marcelo D Boeri, Aristóteles, Acerca del alma, [Acerca del alma] Traducción, notas, prólogo e introducción, Buenos Aires: Colihue, 2010, p. 140 n. 331. 
son lo mismo, ya que sólo la intelección capta las propiedades de la extensión geométrica (con relación a la cual son irrelevantes los aspectos particulares de la representación). Estamos aquí ante una caracterización de dos diferentes operaciones mentales sobre un objeto. La afirmación según la cual no inteligimos sin imágenes no puede implicar, entonces, que los contenidos inteligibles sean idénticos a las imágenes, puesto que el

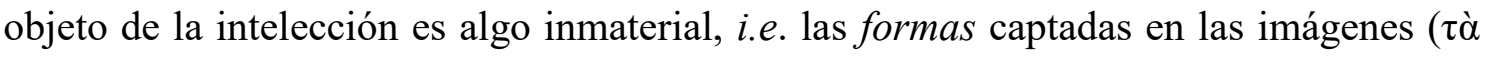

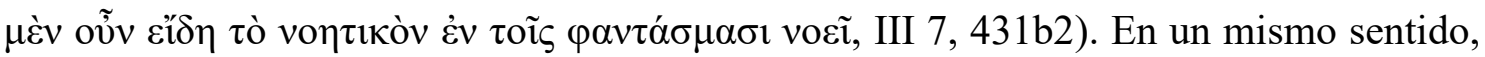
la comparación entre objetos inteligibles y objetos abstractos (431b8 ss.) indica que los objetos del intelecto se toman como separados de lo sensible y material, en lo cual, sin embargo, existen (cfr. la tesis anti-platónica en III 8, 432a3-6); son como lo cóncavo, que se abstrae de lo chato y de la carne o la nariz.

Conviene apreciar mejor con qué se compromete Aristóteles al afirmar que no es posible desarrollar el pensamiento discursivo ni el juicio sin sensación (De An. III 3, 427b15-16) ni contemplar sin captar al mismo tiempo una imagen (lo que requiere el concurso de la imaginación) $(8,432 \mathrm{a} 8-10)$, y también al aceptar que la captación intelectiva de las formas que están presentes en las magnitudes sensibles tiene, en cierto sentido, su punto de partida en una utilización de la senso-percepción y las imágenes (432a3-8). Este compromiso se expresa, por ejemplo, en afirmaciones como las siguientes:

"La facultad de inteligir intelige las formas en las imágenes" (431b2; trad. Boeri).

"Puesto que, según parece, no hay nada $\mid$ separado aparte de las magnitudes sensibles, las cosas inteligibles $\mid$ se dan en las formas sensibles [...] Por eso, tampoco se puede aprender ni comprender nada | si no se tiene percepción; | y cuando se contempla, es necesario que se contemple a la vez por medio de alguna imagen; | pues las imágenes son como los perceptos $\mid$ con la excepción de que <las imágenes> carecen de materia" (432a3-10; texto de Ross pero con la

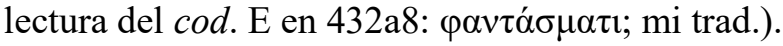

En estos pasajes Aristóteles acepta una cierta dependencia del intelecto respecto de la percepción y de la imaginación, dependencia que se expresa frecuentemente

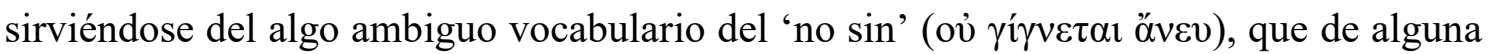
manera constituye la contracara de su rechazo a la identificación de los conceptos con las

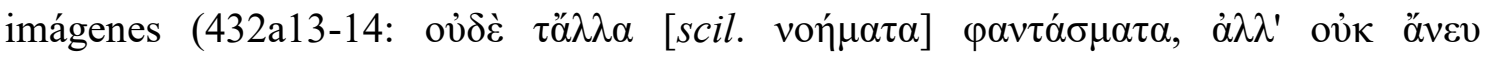
$\varphi \alpha \nu \tau \alpha \sigma \mu \alpha ́ \tau \omega v)$. Pero ¿cuál es el alcance y el carácter que hay que asignar a esa dependencia? Mi sugerencia es que en 432a3-10 Aristóteles afirma que tanto las formas matemáticas como las naturales no existen separadas de los cuerpos (más allá de que sus 
respectivas definiciones planteen distintas exigencias). ${ }^{90}$ Por ello, la aprehensión intelectual de ambas formas depende de perceptos e imágenes (i.e. contenidos que corresponden a la naturaleza sensible de los objetos en los cuales se dan las formas), en el sentido de que no es posible para el intelecto aprehender sus correlatos propios sin que haya una operación representacional previa al nivel de la percepción y la imaginación. En esa operación representacional, la imaginación desempeña un rol central. Ahora bien, la dependencia del intelecto respecto de la imaginación (y la percepción) no parece requerir que la característica sensible que pertenece tanto a los perceptos como a las imágenes se transmita a los correlatos propios del intelecto. Es decir, de la afirmación según la cual no es posible inteligir sin servirse de imágenes no se sigue que los correlatos del intelecto sean (idénticos al tipo de las) imágenes. La dependencia del intelecto con respecto a la senso-percepción y a la imaginación podría caracterizarse, entonces, como una dependencia débil, en la medida en que sólo atañe al hecho de que toda captación intelectual de formas se produce sobre objetos sensibles en los cuales existen las formas. Además, el escalonamiento de las facultades y capacidades cognoscitivas humanas, que admite Aristóteles, requiere poder representarse imaginativamente un objeto antes de formarse conceptos al nivel del intelecto. Una posible explicación (siguiendo la lectura de Wedin) de la dependencia débil en términos de la relación accidental entre las capacidades cognoscitivas sería la siguiente: (i) si bien los objetos del intelecto no se dan sin imaginación, (ii) aunque los objetos propiamente captados por el intelecto no son imágenes, (iii) hay que admitir que la imaginación (y la percepción) capta sólo accidentalmente los objetos del intelecto, y (iv) que la percepción sensorial y la imaginación están envueltas sólo accidentalmente en (los objetos propios de) la intelección. En síntesis, (v) el intelecto humano está forzado a tener que servirse de representaciones internas (i.e. imágenes) de las formas ya que éstas se dan en los objetos

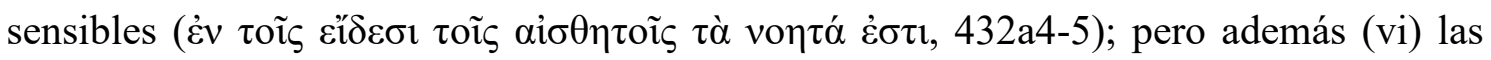
imágenes de que se sirve el intelecto sólo son representaciones accidentales de las formas, lo que explica que las formas no son imágenes. ${ }^{91}$

${ }^{90}$ Para esas distintas exigencias, cfr. Michael Peramatzis, Priority in Aristotle's Metaphysics, [Priority] Oxford: Oxford University Press, 2011, cap. 4.

${ }^{91}$ La noción de representación accidental de las formas es conforme a la relación accidental que Aristóteles releva en la percepción accidental cuando decimos que 'veo al hijo de Calias', en la medida en que veo propiamente algo blanco, lo cual concurrentemente es el hijo de Calias. Cfr. Wedin, Mind and Imagination, pp. 106 ss. Su conclusion es que: "thinking involves imagination only incidentally" (id., 108). Para una discusión de la relación entre imaginación e intelecto, y 


\subsection{La analogía entre intelección y senso-percepción dentro de sus límites}

Como anticipé, una motivación principal para comprometer a Aristóteles con una concepción pictórica del significado y una teoría del intelecto que explica los conceptos en términos de imágenes mentales -como Ackrill le atribuyera a Aristóteles en su influyente comentario- ${ }^{92}$ se apoya en una lectura de la comparación de De Anima III 4, 429a13-18 (cfr. también 6, 430b29-30; y en general III 7). Allí, después de anunciar que se focalizará en la parte intelectiva del alma y tras insistir en que el objetivo del capítulo reside en aclarar en qué consiste el inteligir (429a10-13), Aristóteles traza una analogía entre la intelección y la senso-percepción. El alcance de dicha analogía es muy controvertido. Conviene citar el pasaje:

Si efectivamente el inteligir | es como el percibir sensorialmente, será, o bien un cierto padecer por obra de lo inteligible, o bien | alguna otra cosa de ese tipo. Es forzoso, por tanto, que $<\mathrm{el}$ inteligir > sea impasible y capaz de recibir la $\mid$ forma, y que sea en potencia tal $<$ como la forma $>$, aunque no es esa $<$ forma $>$; y de manera semejante, | tal como la facultad sensitiva es respecto de los sensibles, así también es el intelecto respecto de | los inteligibles (429a13-18; trad. Boeri, con leves modificaciones).

una defensa de la dependencia débil, cfr. Wedin 1988: cap. 4 (en cuya interpretación general me apoyo aquí). En el texto citado de De An. III 8, 432a8, y a pesar de que así se sostiene mejor la lectura del uso instrumental de la imaginación que aquí he suscripto, no es imprescindible, con

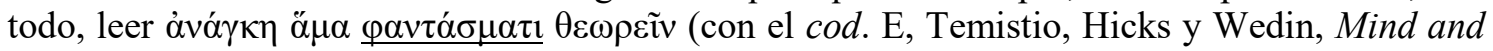
Imagination, pp. 115 s. n. 23), tomando el dativo de instrumento que evita identificar los

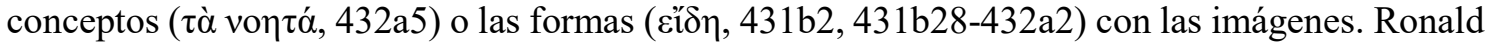
Polanski, Aristotle's De anima, Cambridge: Cambridge University Press, 2007, pp. 498 s., toma

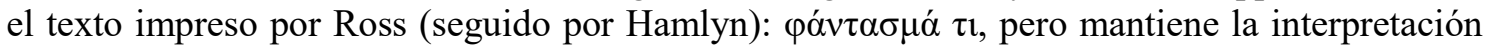
del uso instrumental de la imaginación (en contra de la identificación entre imágenes y conceptos). La conclusion de Wedin, Mind and Imagination, p. 116 (cfr. también pp. 132-136), expresa la interpretación que suscribo: "So it seems clear that an image is a vehicle for thought without being identical with the thought". Cfr. también Charles, Meaning and Essence, pp. 137 s.; Boeri, Acerca del alma, pp. clxv ss.

${ }_{92}$ Ackrill, Categories and The Interpretatione, p. 113: "Aristotle probably calls them [scil. affections of the soul] likenesses of things because he is thinking of images and it is natural to think of the (visual) image of a cat as a picture or likeness of a cat." Ackrill añade: "But the inadequacy of this as an account or explanation of thought is notorious." También, Kretzmann, "Spoken Sound," p. 9, toma las afecciones del alma como mental images, y las asimila a senseimpressions, aunque lo mitiga argumentando que las imágenes (phantásmata) acompañan todos nuestros actos mentales, pero sin que imaginar sea lo mismo que razonar. Una interpretación como ésta entraña aplicar controvertidamente a la intelección el carácter visual que estrictamente sólo pertenece a la phantasía ("producir algo ante nuestros ojos", De An. III 427b19-20; contemplar cosas "como en una pintura", 427b23-24). Ante la implausibilidad de una teoría de tal índole, resulta saludable que De Rijk, Semantics, p. 21 n. 58, recomiende buscar una alternativa aceptable a la traducción corriente de ó $\mu$ oí $\omega \mu \alpha$ como semejanza e imagen. 
A primera vista, la comparación de la intelección con la senso-percepción (

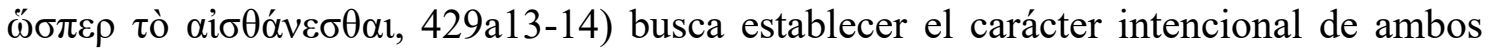
modos de conocer: cada uno de ellos tiene un correlato propio y no intercambiable ( $\tau$ ò

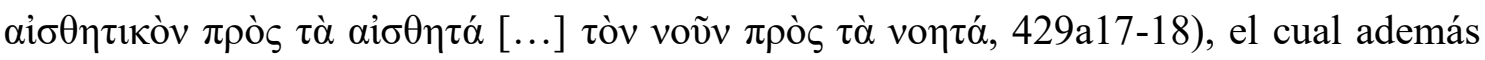

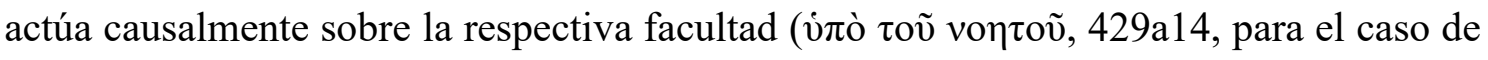
la intelección), produciéndose, como resultado de ello, lo captado en cada una de ellas. ${ }^{93}$ Pero hay otras cosas que la analogía no implica, o no lo hace obligatoriamente, como resulta ya del mero hecho de hablar de correlatos propios y no intercambiables para cada una de las dos facultades comparadas. Así, la analogía no implica que el intelecto sea un órgano como lo es un órgano físico involucrado en la percepción sensible, y definitivamente tampoco implica una identificación entre los objetos de la intelección y de la senso-percepción. En efecto, como hemos visto, la distinción entre los objetos de la sensopercepción respecto de los objetos del intelecto trazada en términos del objeto concreto y particular, para la primera, y de la esencia o forma universal, para la segunda, habla en favor de distinguir dos tipos diferentes de estados mentales y facultades que actúan representacionalmente de manera diversa en la captación de cada uno de esos dos tipos de objeto (429b10 ss., especialmente 429b14-22). Como argumenté en el apartado anterior, tal distinción no se ve anulada por el hecho de que los objetos de la intelección no puedan captarse sin la intervención de la senso-percepción y la imaginación cuya necesaria intervención depende de la suposición aristotélica según la cual las formas están

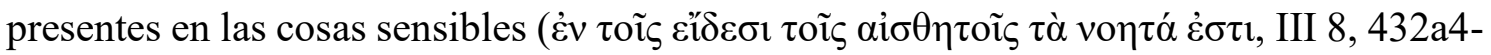
5); o, dicho de otro modo, de la suposición de que las formas no existen ontológicamente

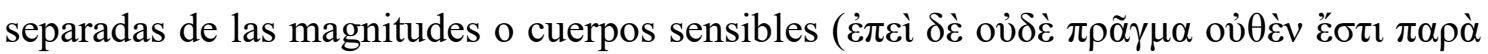
$\tau \grave{\alpha} \mu \varepsilon \gamma \varepsilon \dot{\theta} \theta \eta$, 432a3-4). Es esa suposición relativa al modo de existencia de las formas lo que explica que Aristóteles reclame el concurso necesario de la senso-percepción en la

${ }^{93}$ Charles, Meaning and Essence, p. 111 n. 2, enfatiza que tanto en la senso-percepción como también en la intelección el sujeto llega a asemejarse o se identifica con la forma del objeto correspondiente como resultado de los respectivos procesos, es decir, a su término; mientras que, durante la ejecución de ambos procesos cognoscitivos, bajo la acción causal-eficiente del objeto externo, el sujeto es sólo potencialmente lo que el objeto es actualmente. La forma captada de manera perceptiva o intelectiva llega así (al término del proceso) a estar (actualmente) en la mente (objeto interno), mientras que el objeto afectante de cada una de esas facultades -un objeto sensible qua sentido o un objeto inteligible qua inteligido- se mantiene como algo externo. Charles apoya esta interpretación en pasajes como De An. II 5, 416b35-417a2, 418a3-6, 417a1820; III 8, 431b28 ss.; GC I 7, 324a5-11. 
aprehensión inductiva de los universales (APo. I 18, 81b1-9). ${ }^{94}$ Considerando todo esto, mi sugerencia es, entonces, que la analogía entre senso-percepción e intelección es válida para aclarar aspectos de la intelección, pero debe interpretarse dentro de sus propios límites. ${ }^{95}$

Dentro de tales límites, la asimilación del intelecto al objeto inteligido debe interpretarse en los términos estrictos establecidos por el tipo de objetos allí involucrados, es decir, sin que tal asimilación implique endilgar a Aristóteles una confusión entre conceptos e imágenes sensoriales. En esta línea de lectura, Charles insiste en que la semejanza entre el sujeto que intelige (o "inteligente", en paralelo con "sentiente") y el objeto inteligido, que se alcanza al final del proceso de captación intelectual, tiene que explicarse mediante la acción causal del objeto sobre el intelecto paciente (cfr. De An. III 5). Dando por aceptada ahora la teoría general de la acción y la pasión allí involucrada, ${ }^{96}$ la teoría aristotélica no requiere suponer otros objetos que no sean los estrictamente correspondientes al intelecto, ya que la semejanza es el resultado de la acción de un objeto captado intelectivamente sobre el intelecto paciente. ${ }^{97}$ Charles enfatiza que el uso de asemejar (óhoıṽv en GC I 7, 324a10 s.; De An. II 5, 418a6) y sus derivados (entre ellos,

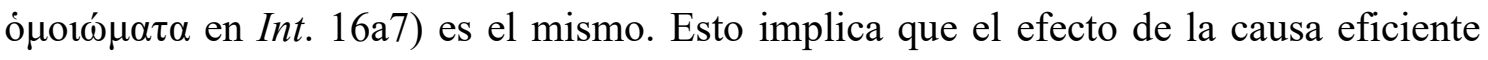
involucrada en la producción de una semejanza mental en De Interpretatione, contrariamente a lo que supusieron Ackrill y Modrak, no puede ser del tipo de una imagen mental ya que esta última corresponde, en cambio, a una clase de representación diferente, la cual sólo se produce por acción de un objeto sensible externo. Por lo tanto, teniendo en cuenta que Aristóteles individúa los estados mentales según los objetos propios que los afectan causalmente, no hay razón para suponer que el resultado de ser afectado por su propio objeto produzca en el intelecto una representación imaginativa, a menos que

${ }^{94} \mathrm{La}$ tesis de la inseparabilidad ontológica de las formas no implica inseparabilidad lógica o definicional (Ph. II 2, 193b33-35; para su interpretación, cfr. Peramatzis, Priority, pp. 70-4).

${ }^{95}$ Charles, Meaning and Essence, p. 112 n. 3, pp. 138-46, señala tres aspectos desemejantes entre senso-percepción e intelección.

${ }^{96}$ Para la interpretación de esto, cfr. Charles, Meaning and Essence, pp. 114 s. (sobre el modelo causal-eficiente de la senso-percepción como asimilación, cfr. id., 112-18).

${ }^{97}$ Otros aspectos complejos y controvertidos de la teoría aristotélica del intelecto en De An. III 46 no resultan ahora imprescindibles para mi discusión. 
estemos dispuestos a hacer colapsar los correlatos del intelecto con los sensibles propios. $^{98}$

\section{Observaciones finales: Imaginación, significado y animales racionales}

Como ya señalé, Modrak sugirió que la imaginación es la principal responsable de determinar los contenidos del intelecto, y, con ello, de alguna manera propuso que los significados lingüísticos pueden explicarse a través de las imágenes. Su interpretación depende de que las ó $\mu$ otó $\mu \alpha \tau \alpha$ de De Interpretatione 16a7 constituyan una clase de vehículo representacional que opera como una imagen mental, i.e. como una semejanza sensible o un દícóv del objeto externo; y además de que las imágenes constituyan una explicación completa del significado. ${ }^{99}$

${ }^{98}$ Cfr. Charles, Meaning and Essence, p. 114 n. 6. Charles (id., pp. 82 ss. y cap. 5) considera que la semejanza, entendida como un proceso causal y unidireccional (en el cual el objeto externo actúa causalmente sobre la facultad respectiva), es el modelo general de que dispone Aristóteles en De Anima para explicar la relación de las facultades con sus propios objetos. Polansky y Kuczewski, "Speech and Thought," pp. 54 s., señalan que identificar el objeto que se capta a través de la intelección con las imágenes sensoriales entrañaría, además, la eliminación de ciertas distinciones que Aristóteles establece ya en el plano de la senso-percepción (cfr. De An. II 7: para el color, y II 8: para el caso paralelo del sonido). Se trata de las distinciones entre (a) el órgano corpóreo afectado, (b) la afección (la sensación propiamente dicha), (c) lo sentido (el contenido interno de la sensación) y (d) el objeto externo que actúa causalmente. El quinto elemento que es preciso distinguir es (e) el medio (e.g. el aire o el agua para la audición del sonido, y la luz para la visión del color). (En III 5, 430a430a15, Aristóteles compara el intelecto activo con el medio de la visión, i.e. la luz que actualiza los colores). Polansky y Kuczewski sugieren, entonces, que Aristóteles distingue cuidadosamente entre (a) y (b)-(c) en la relación que ambos guardan con (d) (a través de (e)). Así, mientras la mano (el órgano en (a)) que percibe algo caliente se calienta, la sensación táctil (b) no adquiere esa cualidad, a pesar de que sentimos calor (el objeto qua sentido en (c)). Lo que se transmite y adquiere a través de la captación sensorial (b) del objeto externo (d) que actúa causalmente -a través del medio apropiado (e)- es, en cambio, el contenido o la forma sensible sin la materia de dicho objeto (se percibe el sensible (c) en cuanto tal, es decir, en cuanto

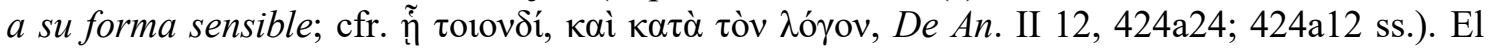
resultado de este proceso es la asimilación cualitativa entre la forma sensible del objeto externo y la forma sentida en la senso-percepción (cfr. De An. II 5, 418a5-6 con GC I 7, 324a9-11), sin transmisión de la materia corpórea del objeto externo. Paralelamente, en la intelección no se transmite ni adquiere aquello que correspondería a lo que en el dominio de los objetos sensibles es la materia corpórea del objeto, sino, en cambio, se transmite y adquiere la sola forma inteligible. Estas cuidadas distinciones, en efecto, no favorecen tomar la intelección como un proceso en el cual se transmite y adquiere una imagen sensible, la cual debe corresponder, más bien, a la materia del objeto externo sobre el cual se ejerce la intelección.

${ }^{99}$ Cfr. Modrak, Language and Meaning, pp. 21 ss., 221, 222 n. 9, 256. "As a mode of sensory representation, phantasia is well placed to be the psychological component of meaning mentioned in De Interpretatione" (id., p. 234). "Phantasia as a psychological faculty that is a mode of representation would be well suited to be the faculty exercised in language use. The phantasma, the sensory content realized as an occurrent cognitive object in an exercise of phantasia, is well placed to be a likeness of an external object" (id., p. 223). En otros lugares, Modrak parece 
Sin embargo, la definición canónica de la phantasía hace implausible conceder a las imágenes el rol explicativo de los significados que Modrak les asigna. En esa definición, Aristóteles establece la dependencia de la phantasía con respecto a la sensación y restringe los objetos de la primera:

"[...] la imaginación es aquello en virtud de lo cual decimos que una cierta imagen $\mid$ se produce

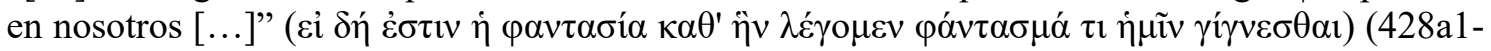
2) (trad. Boeri).

Esta caracterización restringe fuertemente la imaginación al dominio de objetos de la facultad de la senso-percepción, ya que mediante la imaginación producimos imágenes como si los objetos sensibles particulares estuvieran ante nuestros ojos ( $\pi \dot{\alpha} \theta$ o $\varsigma \dot{\varepsilon} \varphi^{\prime} \dot{\eta} \mu \mathrm{i} v$

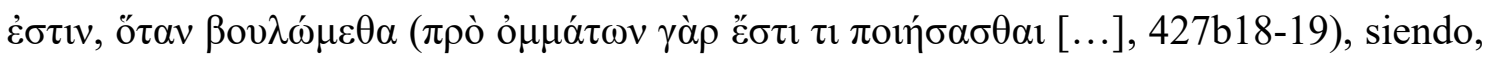
entonces, los correlatos de la phantasía lo que se llama "visiones" (ópó $\mu \alpha \tau \alpha, 428 \mathrm{a} 16$; la correlación imágenes y perceptos se reafirma en 428b14-15, 429a1-2). Esta dependencia de la imaginación con respecto a los objetos de la percepción conlleva que, a diferencia de lo que vimos sucedía con el intelecto, la imaginación se aplica sólo a objetos sensibles

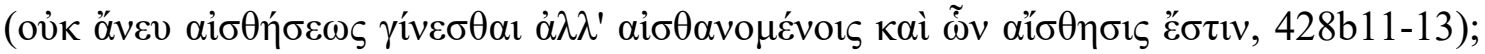
más precisamente, la imaginación se determina como un cierto movimiento resultante de

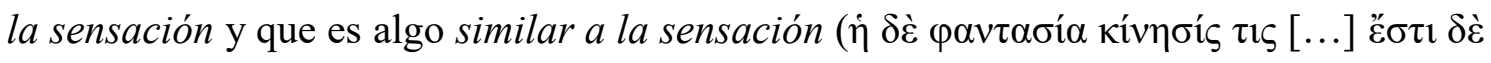

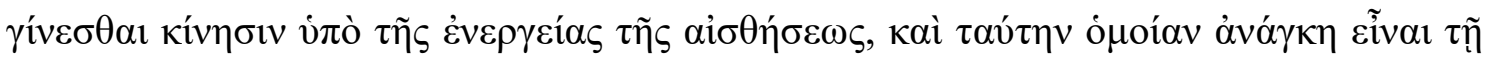

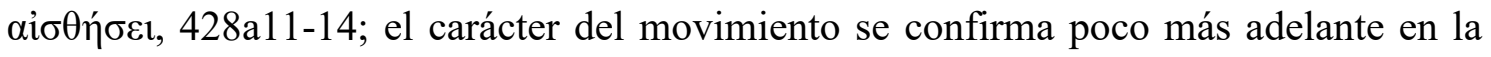

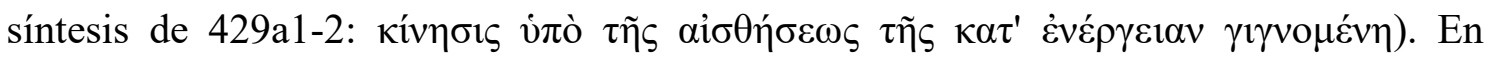
síntesis, la phantasía es un cierto tipo de movimiento (i.e. el que se produce al ser afectado por la percepción, pero que además constituye, de por sí, un movimiento en virtud del cual se pueden producir imágenes y también resultar afectado por ellas) ${ }^{100}$ producido por la percepción, tiene como correlato objetos sensibles y es de aquellas cosas de las cuales tenemos percepción. ${ }^{101}$

sostener algo menos comprometedor sobre la phantasía: que los phantásmata son la base psicológica del significado, y que de esa base formaría parte también la percepción visual de un particular, a partir de la cual se formaría una concepción general al nivel del phántasma (lo que explicaría el definiens) (id., pp. 252, 255 ss.). Sin embargo, ella sigue pensando que la phantasía explica el significado. Una interpretación como ésta enfrenta problemas especiales si, además, acepta que las imágenes pueden efectivamente explicar el carácter complejo de los significados de las oraciones (id.p. 262).

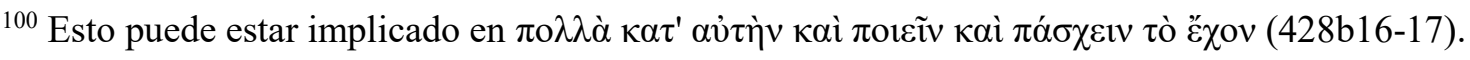

${ }^{101}$ Para un comentario y una interpretación aceptable de la teoría "canónica" de De An. III 3 (especialmente 428b10-429a10), cfr. Wedin, Mind and Imagination, caps. 2-3. La tesis principal 
Sin embargo, hay un pasaje en De Anima II 8 que parece conceder a la imaginación aquello que Modrak afirma. En efecto, en 420b30-33 Aristóteles presenta una descripción sobre la producción de la voz, según la cual ésta resulta del impacto que produce el aire inspirado sobre la tráquea; dicho impacto se produce, a su vez, por la acción del alma presente en esas partes corporales (420b27-29). Aristóteles distingue allí la voz respecto de otros sonidos vocálicos -ya sea que la lengua intervenga o no en su producción- y establece que, para que pueda clasificarse como una voz, un sonido producido en la cavidad bucal debe cumplir dos condiciones (420b29-32): (i) ser un impacto en el que hay un alma que actúa y que está presente en aquellas partes del cuerpo que intervienen en el proceso; ${ }^{102}$ pero además (ii) dicho impacto tiene que estar acompañado de cierta

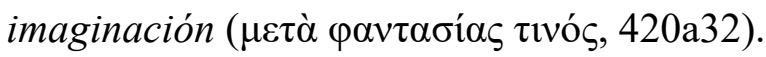

Este pasaje ha llevado a distintos autores a explicar el significado mediante la imaginación. ${ }^{103}$ Sin embargo, hay que advertir que allí Aristóteles persigue un objetivo bastante módico, que está lejos de ser suficiente para revertir el diagnóstico general sobre los límites de la imaginación en la explicación del significado. En efecto, en De Anima II

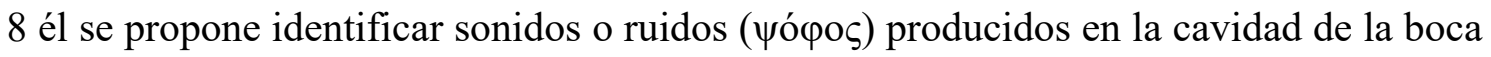
(por ejemplo, la tos), los cuales, aunque carecen de significado, se producen por medio de los mismos mecanismos y partes corporales que intervienen dando lugar a las voces significativas ( $\varphi \omega v \eta ́)$. En 421a4, Aristóteles observa que los peces son mudos (ä $\varphi \omega v o r)$ ya que, en virtud de que carecen de tráquea, no pueden percutir el aire sobre las paredes de la cavidad traqueana, que es el mecanismo necesario para producir ruido vocálico. Allí

de Wedin, según la cual la imaginación es una capacidad (pero no una facultad) general de representación que subyace y coadyuva a otras genuinas facultades psicológicas y funciones (desde la senso-percepción hasta la intelección), no permite proponer que la imaginación sea explicativa del significado, ya que la imaginación sería funcionalmente incompleta, lo que implicaría que, de por sí, carece de objetos propios independientes de las demás facultades genuinas (id., pp. 45-63). Sobre la cuestión de la relación de la phantasía con las demás facultades, cfr. 432a31-b3. Modrak, Language and Meaning, p. 235, sugiere que en virtud de que la sola percepción puede discriminar $\mathrm{y}$, eventualmente, también es responsable de la auto-percepción -más allá de la posible discrepancia entre De Som. 455a13-21 y De An. III 2, 426a12-15-, eso bastaría para hacer de las imágenes los genuinos vehículos de significado. Sin embargo, esto no remueve que la percepción sólo discrimina objetos sensibles, y es cuestionable que tales objetos alcancen para explicar adecuadamente el significado. Aun admitiendo un uso de las imágenes en contextos deliberativos por parte de animales racionales (De An. III 11, 434a5-10), ello no modifica el carácter sensible de los contenidos de la phantasía.

102 En $420 b 31$ leo (con los codd. y los comentadores) ع̌ $\mu \psi v \chi o ́ v$ (impacto “animado"), en contra

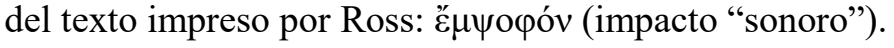

${ }^{103}$ Un posible antecedente de esta lectura se halla en D. W. Hamlyn, Aristotle's De Anima. Books II, III. Translated with Introduction and Notes. Oxford: Oxford University Press, 1968, p. 109. 
$\varphi \omega v \eta ́$ se usa, evidentemente, en el sentido lato que adquiere el vocablo en el marco de esta consideración predominantemente fisiológica. Resulta claro que, aun cuando la fisiología ictícola permitiera a los peces percutir algún órgano usando el aire -como los insectos, que producen sonidos usando el aire exterior (HA IV 9, 535b5-6)-, ni los peces ni los insectos serían capaces de producir voces significativas. Esta última restricción en cuanto a lo que se llama voz en sentido estricto debe estar presente en Historia Animalium IV 9, 536a33-b2 (cfr. también Pol. I 2, 1253a8-15), donde Aristóteles afirma que únicamente los animales racionales desarrollan lenguaje ( $\delta$ ió $\lambda \varepsilon \kappa \tau o \varsigma)$. La correspondencia que para Aristóteles existe entre el tipo de lenguaje (voces articuladas o sonidos no articulados), sus correlatos propios (significados u otro tipo de contenidos y estados intencionales o emociones) y la relación de estos últimos con determinados estados mentales (conceptuales o no conceptuales), parece estar envuelta en la distinción que establece De Interpretatione 2, 16a19-21, donde se diferencian, por un lado, los sonidos significativos y, por el otro, los sonidos inarticulados que son manipulados también por los animales no humanos (16a28-29). Como he señalado (supra 6.4.), Aristóteles contrasta los significados del lenguaje humano con los correlatos propios de las voces de los animales irracionales; para ello, él apela a que los "lenguajes" de los animales no humanos no representan de la misma manera en que lo hace un ó $\mu$ oí $\omega \mu \alpha$, entendido técnicamente en los términos de De Interpretatione 1, 16 a7.

La evidencia que vincula, como acabo de señalar, lenguaje, racionalidad e intelecto es abundante en el corpus. Por ejemplo, en De Generatione Animalium V 6, 786b19-22 se señala que la capacidad de producir sonidos vocálicos (phoné) es natural (aunque no exclusiva) del ser humano en virtud de que sólo él usa el lógos. Allí se aplica el esquema hilemórfico: la voz es la materia del lenguaje, y éste, tomado en sentido estricto, aporta la forma. Mientras que en Historia Animalium IV 9, 535a30 y 535b1-3 se indica que sólo los animales que tienen pulmones para respirar, laringe y lengua pueden producir voces y lenguaje, la posición de De Interpretatione permitiría afirmar que esa condición fisiológica es necesaria pero no suficiente para producir voces significativas. El mecanismo fisiológico especifica lo que resulta necesario y suficiente para producir una voz en sentido lato, pero no lo que resulta suficiente para explicar la voz en sentido 
estricto. ${ }^{104}$ La interpretación que hagamos del papel que se le adjudica a la imaginación en el pasaje de De Anima II 8 (420b30-33) no puede pasar por alto, entonces, la evidencia masiva del corpus, que indica que la imaginación explica suficientemente el comportamiento de los animales no racionales dotados de ciertas capacidades intencionales, mas sin dominio de lenguaje ni de significados en sentido estricto (De An. III 4, 429a6; 10, 433b27-28; 11, 434a4-5; De Mem. 451a15-18; MA 702a15-19; Met. A 1, 980b25-28; EN VII 4, 1147b4-5; HA IV 9, 536a32-b5).

Finalicemos con una imagen general plausiblemente atribuible a Aristóteles. La posición aristotélica que he tratado de presentar aquí admite que para producir voces significativas es necesario contar con una base natural o fisiológica necesaria pero no suficiente para explicar el significado. El antiplatonismo y el anti-reduccionismo de los estados intencionales con respecto a procesos fisiológicos debería llevar coherentemente a suponer que, para Aristóteles, las capacidades específicas de los animales racionales que manejan lenguaje significativo tienen que hallarse involucradas en esa misma base fisiológica, y no como un añadido a la misma desde arriba pero tampoco como una excrecencia de dicha base fisiológica desde abajo. En una imagen así, la racionalidad juega el papel de una segunda naturaleza. Además, si el lenguaje es un componente esencial de las capacidades naturales de los animales racionales, no puede ser un suplemento que provenga desde arriba y no tenga más que una relación de mera superveniencia con las capacidades naturales inferiores o básicas. Lo que se atribuye a Aristóteles al hablar de este modo es que el contenido conceptual de los significados no puede explicarse ni reductivamente ni acumulativamente en relación con ninguna de las capacidades cognoscitivas inferiores (entre las cuales están centralmente la percepción y la imaginación) ni con los componentes de los procesos naturales involucrados, sino que tal explicación requiere incluir desde el inicio el concurso de la facultad del intelecto para dar cuenta adecuada y suficientemente de los estados intencionales a los cuales se asocian los significados. ${ }^{105}$

${ }^{104}$ Como lo propone Wedin, Mind and Imagination, pp. 3, 9-22 (passim), la posición de Aristóteles puede reconstruirse mejor en términos de un anti-reduccionismo de los estados intencionales, involucrados en la explicación del significado, a procesos fisiológicos.

${ }^{105}$ La posición aristotélica sería coherente también con una teoría sobre la experiencia sensoperceptiva de los animales racionales que involucra en ella desde el inicio los conceptos y los significados. Un cuadro general consistente de esta posición ha desarrollado John McDowell, Mind and World, Cambridge (Mass.): Harvard University Press, 1996, Lecture VI; y John McDowell, "Two Sorts of Naturalism," en Mind, Value, and Reality, 167-197, Cambridge (Mass.): Harvard University Press, 1998b. 
Fabián Mié

(CONICET-IHuCSo-Universidad Nacional del Litoral)

\section{Bibliografia}

Aristóteles

Categoriae et Liber De Interpretatione. Recognovit brevique adnotatione critica instruxit Lorenzo Minio-Paluello. Oxford: Oxford University Press, 1949.

De Interpretatione (ПEPI EPMHNEIA 2 ). Recognovit Hermann Weidemann. Bibliotheca Teubneriana. Berlin/Boston: De Gruyter, 2014.

Las restantes obras de Aristóteles se citan según las ediciones en la colección Oxford Classical Texts, con excepción de:

- De generatione animalium (De la géneration des animaux). Text établi et traduit P. Louis. Paris: Les Belles Lettres, 1961.

- De partibus animalium (Les parties des animaux). Texte établi et traduit P. Louis. Paris: Les Belles Lettres, 1957.

- Historia animalium (Histoire des animaux). 3 vols. Texte établi et traduit P. Louis. Paris, 1964: Les Belles Lettres.

- Parva naturalia (Petits Traités d'Histoire Naturelle). Texte établi et traduit R. Mugnier. Paris: Les Belles Lettres, 1965.

- Topiques I-IV. Texte établi et traduit J. Brunschwig. Paris: Les Belles Lettres, 1967.

- De Motu Animalium. Text with translation and notes by M. Craven Nussbaum. Princeton (N.J.): Princeton University Press, 1978.

Platón

Opera, vol I. Recognoverunt brevique adnotatione critica instruxerunt E.A. Duke et alii (Cratylus: W.S.M. Nicoll). Oxford: Oxford University Press, 1995.

Ackrill, John L. Aristotle's Categories and De Interpretatione. Translated with notes. Oxford: Oxford University Press, $1970^{2}$.

Ademollo, Francesco. The Cratylus of Plato: A Commentary. New York: Cambridge University Press: 2011.

Ademollo, Francesco. "Recensión de De interpretatione (ПEPI EPMHNEIA $)$ ), recognovit Hermann Weidemann," Gnomon 89/8 (2017): 683-9.

Amonio. In Aristotelis De Interpretatione commentarius, A. Busse (ed.), Commentaria in Aristotelem Graeca IV. 5. Berlin: Reimer, 1897. 
Anagnostopoulos, Giorgos. "Plato's Cratylus: The Two Theories of the Correctness of Names," The Review of Metaphysics 25 (1971): 691-736.

Araos, Jaime. La filosofía aristotélica del lenguaje. Pamplona: Eunsa, 1999.

Aubenque, Pierre. Le problème de l'être chez Aristote. Essai sur le problématique aristotélicienne. Paris: Presses Universitaires de France, $1994^{2}$.

Aubenque, Pierre. "Aristote et le langage," (1967) reed. en Problèmes aristotéliciens, I Philosophie théorique, 11-30. Paris: Vrin, 2009.

Aubenque, Pierre 1991. "Herméneutique et ontolologie: a propos du Peri Hermeneias," (1991), reed. en Problèmes aristotéliciens, I Philosophie théorique, 101-113. Paris: Vrin, 2009.

Barnes, Jonathan (ed.). The Complete Works of Aristotle. The Revised Oxford Translation. Volume One. Princeton: Princeton University Press (Bollingen Series), 1995.

Barney, Rachel. "Plato on Conventionalism," Phronesis 42/2 (1997): 143-62.

Belardi, Walther. Il linguaggio nella filosofia di Aristotele, Roma, 1975.

Bernabé Pajares, Alberto. Aristóteles, Tratados breves de historia natural (introducción, traducción y notas). Madrid: Gredos, 1987.

Berti, Enrico. "Significato, denotazione ed essenza in Aristotele," (1988), reed. en Nuovi Studi Aristotelici, vol. I. Epistemologia, logica e dialettica, 215-25. Brescia: Morcelliana, 2004.

Boeri, Marcelo D. Aristóteles, Acerca del alma. Traducción, notas, prólogo e introducción. Buenos Aires: Colihue, 2010.

Boethius, Anicius Manlius Severinus (Boecio). Commentarii in librum Aristotelis $\pi \varepsilon \rho \grave{~} \dot{\varepsilon} \rho \mu \eta v \varepsilon i ́ \alpha \varsigma$. Pars prior, versionem continuam et primam editionem continens, Carolus Meisner (ed.). Leipzig: Teubner, 1877.

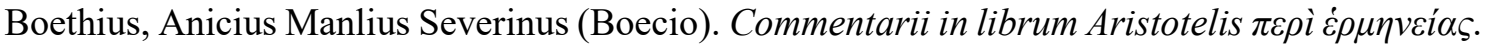
Pars posterior, secundam editionem et indices continens, Carolus Meisner, (ed.). Leipzig: Teubner, 1880.

Boethius, Anicius Manlius Severinus (Boecio). On Aristotle, On Interpretation 4-6. Translated by Andrew Smith, Ancient Commentators on Aristotle. London: Bloomsbury, 2011.

Bolton, Robert. "Essentialism and Semantic Theory in Aristotle: Posterior Analytics, II, 7-10," The Philosophical Review 85 (1976): 514-44.

Bonitz, Hermann. Index Aristotelicus. Graz: Akademischer Druck- und Verlagsanstalt, $1955^{2}$.

Candel Sanmartín, Miguel. Aristóteles, Tratados de Lógica (Órganon). Vol. II. Madrid: Gredos, 1995.

Charles, David. Aristotle on Meaning and Essence. Oxford: Oxford University Press, 2000.

Crivelli, Paolo. Aristotle on Truth. Cambridge: Cambridge University Press, 2004.

De Rijk, Lambertus Marie. Aristotle: Semantics and Ontology. Volume I Semantics and Ontology. Leiden: Brill, 2002.

Evans, Gareth. The Varieties of Reference. John McDowell (ed.). Oxford: Oxford University Press, 1982.

Fine, Gail. "Plato on Naming," Philosophical Quarterly 27/109 (1977): 289-301. Frede, Michael und Patzig, Günther. Aristoteles, Metaphysik Z. Text, Übersetzung und Kommentar. 2 Bände. Munich: Beck, 1988.

Frege, Gottlob. “Über Sinn und Bedeutung," Zeitschrift für Philosophie und philosophische Kritik 100 (N.S.) (1892): 25-60 (citado según la paginación original en la reed. en Gottlob Frege, 
Funktion, Begriff, Bedeutung, Günther Patzig (ed.), pp. 40-65, Göttingen: Vandenhoeck \& Ruprecht, 19947).

Gohlke, Paul. Die Entstehung der Aristotelischen Logik, Berlin: Reimer, 1936.

Hamlyn, D. W. Aristotle's De Anima. Books II, III. Translated with Introduction and Notes. Oxford: Oxford University Press, 1968.

Hicks, R. D. Aristotle: De Anima. Text with English Translation and Notes. Cambridge: Cambridge University Press, 1907.

Hudry, Jean-Louis. "Aristotle on Meaning," Archiv für Geschichte der Philosophie 93 (2011): $253-80$.

Irwin, Terence H. "Aristotle's Concept of Signification," en Language and Logos: Studies in Ancient Philosophy (Festschrift G. Vlastos), Malcolm Schofield and Martha Nussbaum (eds.), 241-66. Cambridge: Cambridge University Press, 1982.

Jacobs, William. “Aristotle on Nonreferring Subjects," Phronesis 24 (1979): 282-300.

Kapp, Ernst. Greek Foundations of Traditional Logic. New York: Columbia University Press, 1942.

King, R. A. H. Aristoteles, De Memoria et Reminiscentia. Übersetzt und erläutert. En Aristoteles. Werke in deutscher Ubersetzungm Bd. 14, Parva naturalia, Teil III, Berlin: Akademie-Verlag, 2004.

Kretzmann, Norman. "Plato on the Correctness of Names," American Philosophical Quarterly, 8/2 (1971): 126-38.

Kretzmann, Norman. "Aristotle on Spoken Sound Significant by Convention," en Ancient Logic and Its Modern Interpretations, John Corcoran (ed.), 3-21. Dordrecht/Boston: Reidel, 1974.

Labarrière, Jean-Louis. "Imagination humaine et imagination animale chez Aristote", Phronesis 29 (1984): 17-49.

Liddell, H. G. and Scott, R. A Greek-Englisch Lexicon. Compiled by H. G. Liddell. Revised and augmented throughout by Sir H. Stuart Jones with the assistance of R. McKenzie and with the cooperation of many scholars. With a Supplement (1968) edited by E. A. Barber with the assistance of P. Maas, M. Scheller and M. L. West. Oxford: Oxford University Press, 1992.

McDowell, John. Mind and World. Cambridge (Mass.): Harvard University Press, 1996.

McDowell, John. "Singular Thought and the Extent of Inner Space," en Meaning, Knowledge, and Reality, 228-259. Cambridge (Mass.): Harvard University Press, 1998a.

McDowell, John. "Two Sorts of Naturalism," en Mind, Value, and Reality, 167-197. Cambridge (Mass.): Harvard University Press, 1998 b.

Maier, Heinrich. Die Syllogistik des Aristoteles. I, II/1, II/2. Leipzig: Teubner, $1936^{2}$ (1 ra. ed. 1896-1900).

Magee, J. Boethius on Signification and Mind, Leiden/New York/Kopenhagen/Köln: Brill, 1989.

Mittelmann, Jorge. Aristóteles, Categorías. Sobre la interpretación. Introducción, traducción y notas. Buenos Aires: Losada, 2008.

Modrak, Deborah K. W. Aristotle's Theory of Language and Meaning, Cambridge (U.K): Cambridge University Press, 2001.

Mombello, Eduardo H. Aristóteles, Ser y Decir: Una reconstrucción de la doctrina de la referencia en la teoría del lenguaje y de la ciencia (Universidad Nacional de Córdoba, 2011, Tesis doctoral, inédita).

Montanari, Elio. La sezione linguistica del Peri Hermeneias di Aristotele. Firenze: Olschki, 1984 (vol. I), 1988 (vol. II). 
Mora-Márquez, Ana María. "Peri Hermeneias 16a3-8. Histoire d'une rupture de la tradition interprétative dans le bas Moyen Âge," Revue Philosophique de la France et de l'Étranger 201/136 (2011): 67-84.

Oehler, Klaus. Die Lehre vom Noetischen und Dianoetischen Denken bei Platon und Aristoteles. Ein Beitrag zur Erforschung des Bewusstseinsproblem in der Antike, Hamburg: Meiner, $1985^{2}$.

Pépin, Jean. " $\Sigma$ YMBO $\Lambda$ A, $\Sigma$ EMEIA, 'OMOIOMATA. A propòs de De Interpretatione 1, 16a38 et Politique VIII 5, 1340a6-39," en Aristoteles: Werk und Wirkung. Band I, Jürgen Wiesner (ed.), 22-44, Berlin: De Gruyter, 1985.

Peramatzis, Michael. Priority in Aristotle's Metaphysics. Oxford: Oxford University Press, 2011.

Polanski, Ronald. Aristotle's De anima. Cambridge: Cambridge University Press, 2007.

Polansky, Ronald and Kuczewski, Mark. "Speech and Thought, Symbol and Likeness: Aristotle's De Interpretatione 16a3-9," Apeiron: A Journal for Ancient Philosophy and Science 23/1 (1990): 51-63.

Putnam, Hilary. "Meaning, Other People, and the World," en Representation and Reality, 19-41. Cambridge (Massachusetts): The MIT Press, 1988.

Rabossi, Eduardo. "Lenguaje, pensamiento y realidad. Peri Hermeneias 16a," Revista Latinoamericana de Filosofia VIII/2 (1982): 169-80.

Sainati, Vittorio. Storia del "Organon" aristotélico. I Dai "Topici" al "De Interpretatione". Firenze: Leo Olschki, 1968.

Sedley, David. "Aristotle's De Interpretatione and Ancient Semantics," en Knowledge through Signs. Ancient Semiotic Theories and Practices, G. Manetti (ed.), Turnhout, 1996, 87-108

Sedley, David. Plato's Cratylus. Cambridge (U.K.): Cambridge University Press, 2003.

Sinnott, A. Eduardo. Untersuchungen zur Kommunikation und Bedeutung bei Aristoteles, Münster: Nodus Verlag, 1989.

Tomás de Aquino. Expositio libri Peri Hermeneias, Opera omnia iussu Leonis [...], tomus I, Editio altera [...], Roma/Paris, 1989.

Van der Eijk, Philip J. Aristoteles. De insommniis. De diuinatione per somnum. Übersetzt und erläutert. En Aristoteles. Werke in deutscher Übersetzung Bd. 14, Parva naturalia, Teil III, Berlin: Akademie-Verlag, 1994.

Waitz, Theodore. Aristotelis, Organon Graece. Novis codicum auxiliis adiunctus recognovit, scholiis ineditis et comentario instruxit T.W. Pars prior. Leipzig: Teubner, 1844.

Wedin, Michael. Mind and Imagination in Aristotle. New Haven and London: Yale University Press, 1998.

Weidemann, Hermann. Aristoteles, Peri Hermeneias. Übersetzt und erläutert. En Aristoteles, Werke in Deutscher Übersetzung, Band 1/II. Berlin: Akademie Verlag, 2002².

Weidemann, Hermann. "War Aristoteles ein Repräsentationalist", en Ancient and Medieval Theories of Intentionality, Dominik Perler (ed.), 97-104. Leiden: Brill, 2001.

Whitaker, C. W. A. Aristotle's De Interpretatione. Contradiction and Dialectic. Oxford: Oxford University Press, 1996.

Zirin, R. "Inarticulate Noises," en Ancient Logic and Its Modern Interpretations, John Corcoran (ed.), 23-5. Dordrecht/Boston: Reidel, 1974. 